University of Nebraska - Lincoln DigitalCommons@University of Nebraska - Lincoln

USGS Staff -- Published Research

US Geological Survey

2014

\title{
Biogeochemical aspects of uranium mineralization, mining, milling, and remediation
}

Kate M. Campbell

USGS, kcampbell@usgs.gov

Tanya J. Gallegos

USGS

Edward R. Landa

USGS; Department of Environmental Science and Technology, University of Maryland

Follow this and additional works at: http://digitalcommons.unl.edu/usgsstaffpub

Part of the Earth Sciences Commons, and the Environmental Sciences Commons

Campbell, Kate M.; Gallegos, Tanya J.; and Landa, Edward R., "Biogeochemical aspects of uranium mineralization, mining, milling, and remediation" (2014). USGS Staff -- Published Research. 852.

http://digitalcommons.unl.edu/usgsstaffpub/852

This Article is brought to you for free and open access by the US Geological Survey at DigitalCommons@University of Nebraska - Lincoln. It has been accepted for inclusion in USGS Staff -- Published Research by an authorized administrator of DigitalCommons@University of Nebraska - Lincoln. 


\title{
Biogeochemical aspects of uranium mineralization, mining, milling, and remediation
}

\author{
Kate M. Campbell ${ }^{\mathrm{a}, *}$, Tanya J. Gallegos ${ }^{\mathrm{b}}$, Edward R. Landa ${ }^{\mathrm{c}, \mathrm{d}}$ \\ a USGS, 3215 Marine Street, Boulder, CO 80303, USA \\ bUSGS, Denver, CO, USA \\ ' USGS, Reston, VA, USA \\ ${ }^{\mathrm{d}}$ Department of Environmental Science and Technology, University of Maryland, College Park, MD, USA
}

\section{A R T I C L E I N F O}

\section{Article history:}

Available online $\mathrm{xxxx}$

\begin{abstract}
A B S T R A C T
Natural uranium (U) occurs as a mixture of three radioactive isotopes: ${ }^{238} \mathrm{U},{ }^{235} \mathrm{U}$, and ${ }^{234} \mathrm{U}$. Only ${ }^{235} \mathrm{U}$ is fissionable and makes up about $0.7 \%$ of natural $\mathrm{U}$, while ${ }^{238} \mathrm{U}$ is overwhelmingly the most abundant at greater than $99 \%$ of the total mass of U. Prior to the 1940 s, U was predominantly used as a coloring agent, and U-bearing ores were mined mainly for their radium ( $\mathrm{Ra}$ ) and/or vanadium (V) content; the bulk of the U was discarded with the tailings (Finch et al., 1972). Once nuclear fission was discovered, the economic importance of $U$ increased greatly. The mining and milling of $U$-bearing ores is the first step in the nuclear fuel cycle, and the contact of residual waste with natural water is a potential source of contamination of $U$ and associated elements to the environment. Uranium is mined by three basic methods: surface (open pit), underground, and solution mining (in situ leaching or in situ recovery), depending on the deposit grade, size, location, geology and economic considerations (Abdelouas, 2006). Solid wastes at U mill tailings (UMT) sites can include both standard tailings (i.e., leached ore rock residues) and solids generated on site by waste treatment processes. The latter can include sludge or "mud" from neutralization of acidic mine/mill effluents, containing Fe and a range of coprecipitated constituents, or barium sulfate precipitates that selectively remove Ra (e.g., Carvalho et al., 2007). In this chapter, we review the hydrometallurgical processes by which $U$ is extracted from ore, the biogeochemical processes that can affect the fate and transport of $U$ and associated elements in the environment, and possible remediation strategies for site closure and aquifer restoration.

This paper represents the fourth in a series of review papers from the U.S. Geological Survey (USGS) on geochemical aspects of UMT management that span more than three decades. The first paper (Landa, 1980 ) in this series is a primer on the nature of tailings and radionuclide mobilization from them. The second paper (Landa, 1999) includes coverage of research carried out under the U.S. Department of Energy's Uranium Mill Tailings Remedial Action Program (UMTRA). The third paper (Landa, 2004) reflects the increased focus of researchers on biotic effects in UMT environs. This paper expands the focus to $U$ mining, milling, and remedial actions, and includes extensive coverage of the increasingly important alkaline in situ recovery and groundwater restoration.
\end{abstract}

(c) 2014 Published by Elsevier Ltd.

\section{Contents}

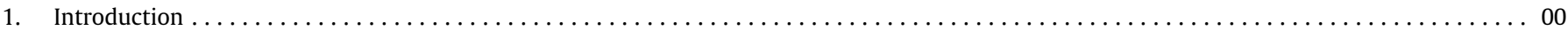

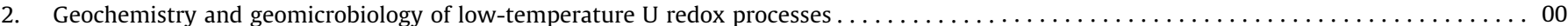

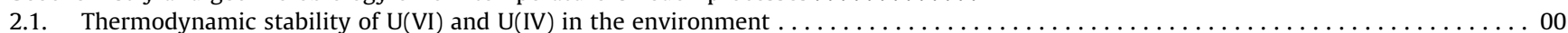

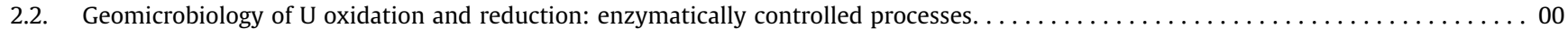

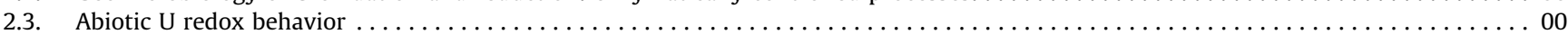

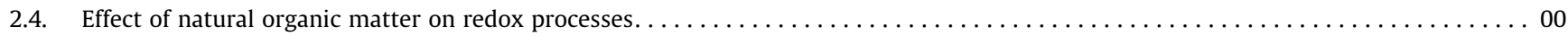

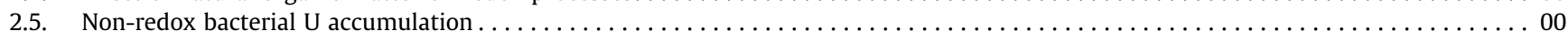

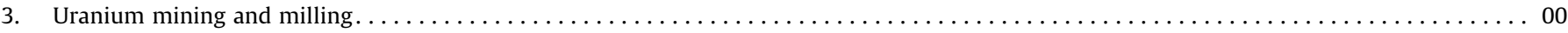

\footnotetext{
* Corresponding author. Tel.: +1 3035413035.

E-mail address: kcampbell@usgs.gov (K.M. Campbell).
} 


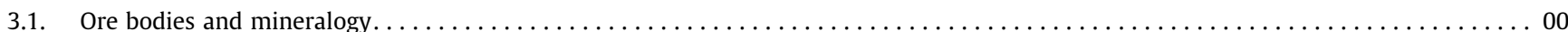

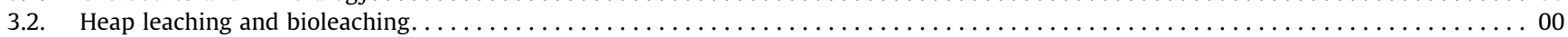

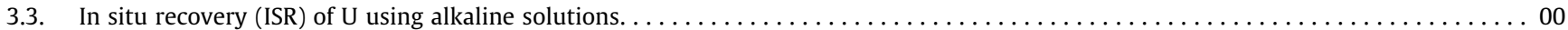

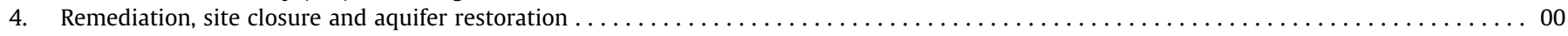

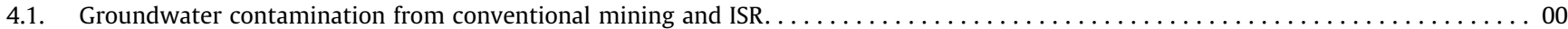

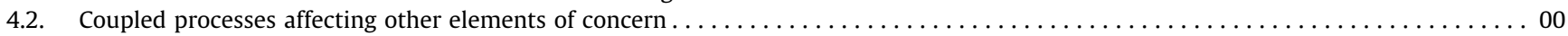

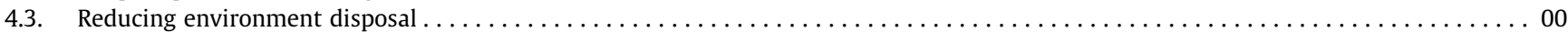

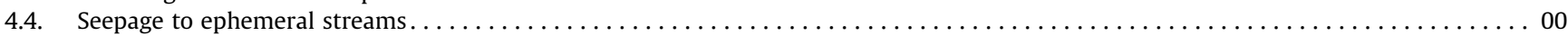

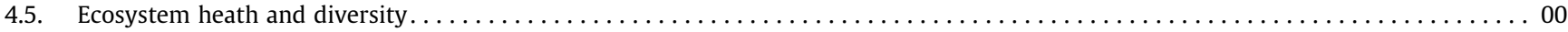

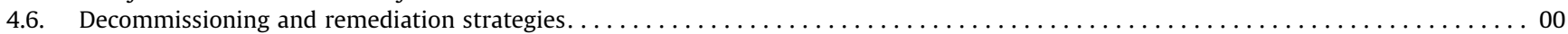

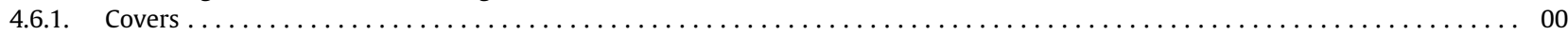

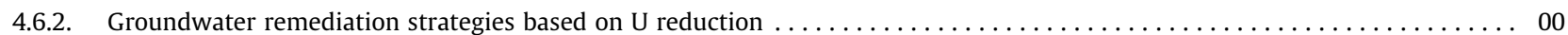

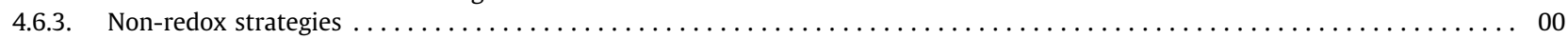

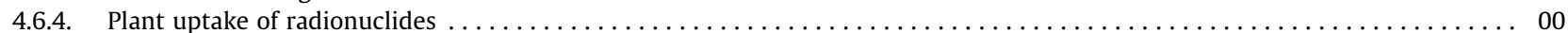

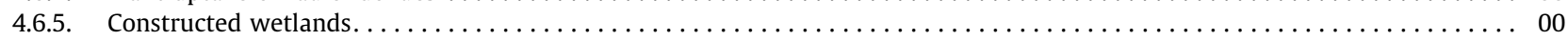

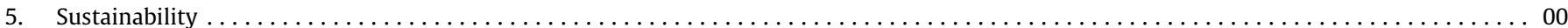

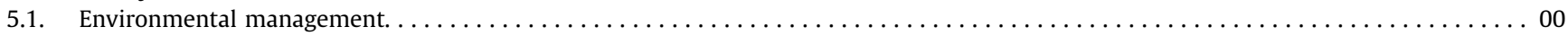

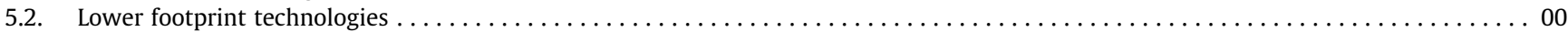

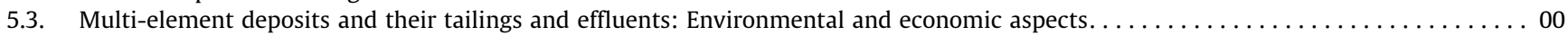

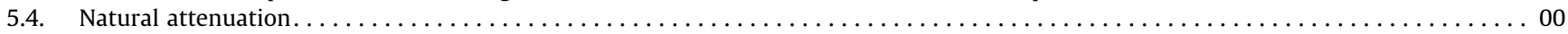

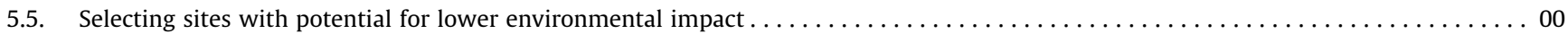

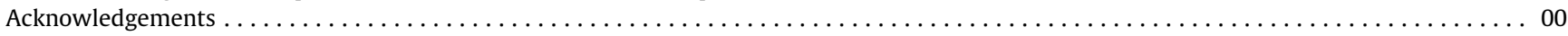

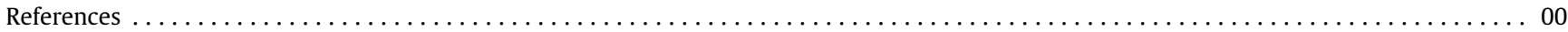

\section{Introduction}

Natural uranium (U) occurs as a mixture of three radioactive isotopes: ${ }^{238} \mathrm{U},{ }^{235} \mathrm{U}$, and ${ }^{234} \mathrm{U}$. Only ${ }^{235} \mathrm{U}$ is fissionable and makes up about $0.7 \%$ of natural $U$, while ${ }^{238} U$ is overwhelmingly the most abundant at greater than $99 \%$ of the total mass of U. Prior to the 1940 s, U was predominantly used as a coloring agent, and U-bearing ores were mined mainly for their radium ( $\mathrm{Ra}$ ) and/or vanadium (V) content; the bulk of the $U$ was discarded with the tailings (Finch et al., 1972). Once nuclear fission was discovered, the economic importance of $U$ increased greatly. The mining and milling of U-bearing ores is the first step in the nuclear fuel cycle, and the contact of residual waste with natural water is a potential source of contamination of $U$ and associated elements to the environment. Uranium is mined by three basic methods: surface (open pit), underground, and solution mining (in situ leaching or in situ recovery), depending on the deposit grade, size, location, geology and economic considerations (Abdelouas, 2006). Solid wastes at $\mathrm{U}$ mill tailings (UMT) sites can include both standard tailings (i.e., leached ore rock residues) and solids generated on site by waste treatment processes. The latter can include sludge or "mud" from neutralization of acidic mine/mill effluents, containing Fe and a range of coprecipitated constituents, or barium sulfate precipitates that selectively remove Ra (e.g., Carvalho et al., 2007). In this chapter, we review the hydrometallurgical processes by which $U$ is extracted from ore, the biogeochemical processes that can affect the fate and transport of $U$ and associated elements in the environment, and possible remediation strategies for site closure and aquifer restoration.

This paper represents the fourth in a series of review papers from the U.S. Geological Survey (USGS) on geochemical aspects of UMT management that span more than three decades. The first paper (Landa, 1980) in this series is a primer on the nature of tailings and radionuclide mobilization from them. The second paper (Landa, 1999) includes coverage of research carried out under the U.S. Department of Energy's Uranium Mill Tailings Remedial Action Program (UMTRA). The third paper (Landa, 2004) reflects the increased focus of researchers on biotic effects in UMT environs. This paper expands the focus to $U$ mining, milling, and remedial actions, and includes extensive coverage of the increasingly important alkaline in situ recovery and groundwater restoration.

\section{Geochemistry and geomicrobiology of low-temperature $U$ redox processes}

There are several reviews of $U$ geochemistry in the literature, including Wanty et al. (1999) and Langmuir (1978, 1997). The discussion below is intended to summarize some of the salient aspects of $U$ geochemistry, with an emphasis on redox transformations.

\subsection{Thermodynamic stability of $U(V I)$ and $U(I V)$ in the environment}

Generally, oxidized $U$ [ $U$ with a formal charge of +6 ] is more mobile in water than reduced forms of $U$ [U(V), U(IV)]. The dominant aqueous species of $\mathrm{U}(\mathrm{VI})$ depends upon the $\mathrm{pH}$ and geochemical conditions, particularly the concentration of strong complexing agents such as inorganic carbon, phosphorous and fluoride, and ternary complexing species such as magnesium and calcium. In speciation calculations of a simplified oxic natural water [U(VI), $\mathrm{Ca}^{2+}, \mathrm{CO}_{2(\mathrm{~g})}, \mathrm{SO}_{4}^{2-}, \mathrm{Na}^{+}$, and $\mathrm{Cl}^{-}$as components], aqueous $\mathrm{U}(\mathrm{VI})$-sulfate complexes are dominant at low $\mathrm{pH}$ (1.5-5), whereas at neutral to basic $\mathrm{pH}, \mathrm{U}(\mathrm{VI})$-carbonate and $\mathrm{Ca}-\mathrm{U}(\mathrm{VI})$-carbonate ternary complexes dominate (Fig. 1). The large number of possible aqueous species depends on the chemical composition of the water, as illustrated in the pronounced differences in calculated species in Fig. 1A (no sulfate) and 1B (with sulfate). Oxidized $\mathrm{U}$ also forms numerous solid precipitates and adsorbed complexes on mineral surfaces, which will be discussed in following sections. Uranium $(V)$ is rarely found in any appreciable amount in the environment because it is usually a short-lived intermediate that readily disproportionates into $\mathrm{U}(\mathrm{IV})$ and $\mathrm{U}(\mathrm{VI})$ (Ilton et al., 2005; Großmann et al., 2007). Reduced U(IV) has a very low aqueous solubility except at low $\mathrm{pH}$, which may be a consideration in acidic mine and tailings sites.

The redox potential of the $\mathrm{U}(\mathrm{IV}) / \mathrm{U}(\mathrm{VI})$ couple depends upon the aqueous $U$ speciation, and consequentially, the geochemistry of the water governs that speciation (Wan et al., 2005; Ginder-Vogel et al., 2006). For example, the equilibrium between $\mathrm{U}(\mathrm{VI})$ and $\mathrm{U}(\mathrm{IV})$ can shift upon a change in $\mathrm{pH}, \mathrm{pCO}_{2}, \mathrm{Mg}$ and/or Ca concentrations in natural water. These changes may greatly affect the thermodynamic potential for a redox reaction to occur (Fig. 2). Generally, $\mathrm{U}(\mathrm{VI})$ is expected in oxic and suboxic waters, whereas 


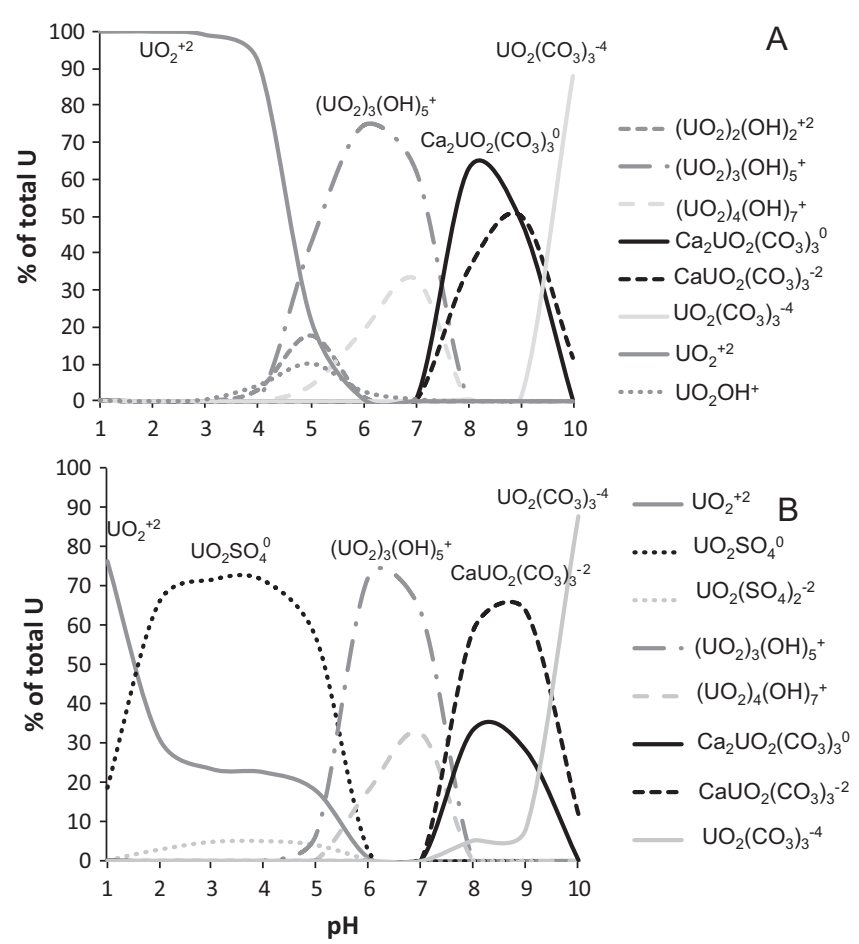

Fig. 1. Aqueous chemical speciation of $U(V I)$ as a function of $\mathrm{pH}$ in simplified natural water matrix. Panel A was calculated with $0.1 \mathrm{mM} \mathrm{U}, 1 \mathrm{mM} \mathrm{Ca}, 10^{-3.5} \mathrm{~atm}$ $\mathrm{CO}_{2}$, and $\mathrm{NaCl}$ as an ionic strength buffer. In Panel B, $8 \mathrm{mM}$ sulfate was added to the calculation. Calcite was allowed to precipitate in both simulations. Speciation was calculated with visual MINTEQ geochemical speciation code (Gustafsson, 2010) with uranyl equilibrium constants from (Guillamont et al., 2003; Dong and Brooks, 2006). Any species less than $1 \%$ of the total $U$ was not plotted.

$\mathrm{U}(\mathrm{IV})$ is stable in anoxic conditions. However, the kinetics of biogeochemical reactions are commonly the primary controlling factors of oxidation state, and thus, $\mathrm{U}(\mathrm{VI})$ can persist in reducing environments. Uranium(IV) tends to have faster oxidation kinetics and is less likely to be found in oxidizing environments except at low $\mathrm{pH}$.

\subsection{Geomicrobiology of $U$ oxidation and reduction: enzymatically controlled processes}

For many years, abiotic processes were thought to be the dominant $U$ redox-controlling reactions under environmentally relevant conditions. However, more recent evidence suggests that microbially mediated redox reactions are critically important to $\mathrm{U}$ redox cycling. The importance of coupled biotic/abiotic $U$ redox processes cannot be underestimated. For example, the reduction of $\mathrm{Fe}(\mathrm{III})$ by metal-reducing bacteria can produce $\mathrm{Fe}(\mathrm{II})$, which can act as an electron donor for abioic $\mathrm{U}(\mathrm{VI})$ reduction. Many reducing agents found in the environment are present due to microbial metabolism, whereas the processes of adsorption, precipitation, mineral-electron transfer, and complexation can simultaneously affect the oxidation state and the mobility of $U$. It is often difficult to quantitatively identify the relative importance of abiotic or biotic processes and how a perturbation will affect the redox balance of such a complex system. However, this information is important for predictive models, where natural or artificial changes in redox conditions are the basis for mining or remediation planning decisions.

Oxidation of U(IV) at circumneutral pH under anaerobic conditions has been shown to occur during microbial nitrate reduction (denitrification) in the presence of $\mathrm{Fe}(\mathrm{III})$ and nitrate reducing organisms, including Geobacter, Arthrobacter, Klebsiella, and Thioba-

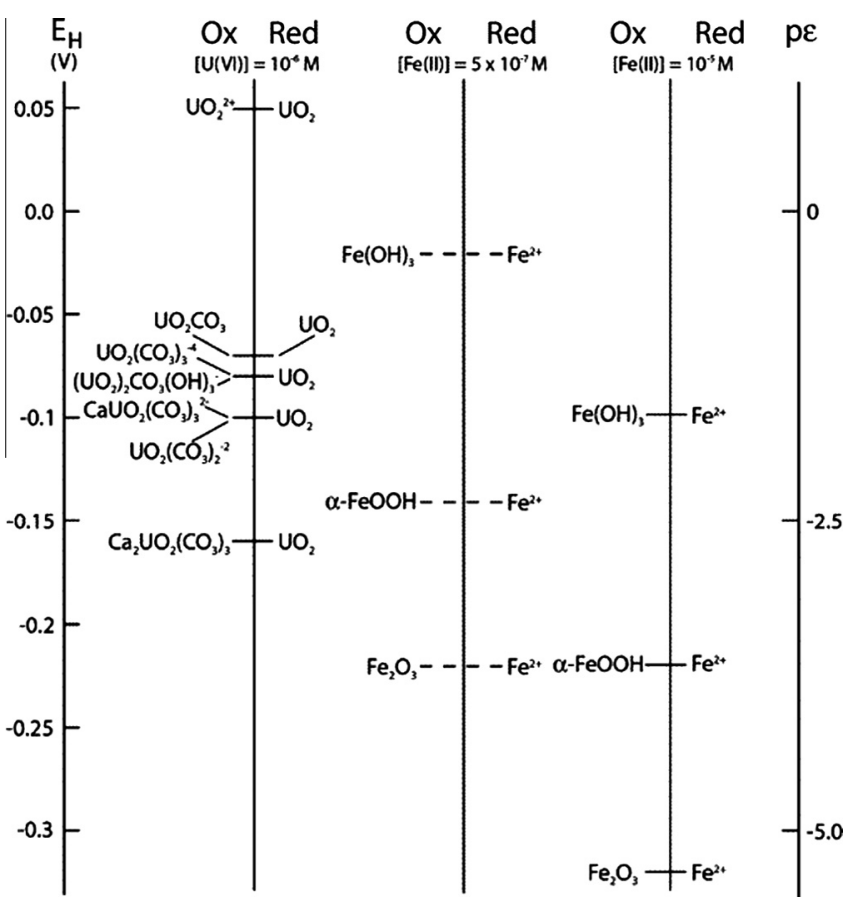

Fig. 2. $\mathrm{Fe}(\mathrm{III}) / \mathrm{Fe}(\mathrm{II})$ and $\mathrm{U}(\mathrm{VI}) / \mathrm{U}(\mathrm{IV})$ redox couples at $\mathrm{pH} 7,3 \times 10^{-3} \mathrm{M}$ bicarbonate, $1 \mu \mathrm{M} \mathrm{U}(\mathrm{VI})$, and $1 \mathrm{mM} \mathrm{Ca}{ }^{2+}$. Reprinted with permission from Ginder-Vogel et al. (2006), copyright 2006 by the American Chemical Society.

cillus species (Finneran et al., 2002; Beller, 2005; Geissler and Selenska-Pobell, 2005; Senko et al., 2005a, 2005b; Suzuki and Suko, 2006). This process was not linked to cell growth and may proceed via an indirect pathway of reaction with intermediate products of denitrification $\left(\mathrm{NO}_{2}^{-}, \mathrm{NO}, \mathrm{N}_{2} \mathrm{O}\right)$.

At $\mathrm{pH}<4, \mathrm{U}(\mathrm{IV})$ is more soluble and can be kinetically stabilized to abiotic oxidation by dissolved oxygen (Rai et al., 1990). Under these conditions, microbially mediated aerobic oxidation is possible and has been observed by the autotrophic Acidithiobacillus ferrooxidans (formerly known as Thiobacillus ferrooxidans), a wellstudied organism commonly found in acid rock drainage. This organism is able to grow by catabolically coupling the oxidation of $\mathrm{U}(\mathrm{IV})$ to the reduction of $\mathrm{O}_{2}$, similar to its ability to grow via the oxidation of $\mathrm{Fe}(\mathrm{II})$ at low $\mathrm{pH}$ (DiSpirito and Tuovinen, 1989; Suzuki and Suko, 2006). Uranium(IV) oxidation can occur directly by microbial growth or indirectly by oxidation of $\mathrm{Fe}(\mathrm{II})$ to $\mathrm{Fe}(\mathrm{III})$, an oxidant for U(IV) (Ginder-Vogel et al., 2006). Although A. ferrooxidans is often used in laboratory studies because it is easily cultured in the laboratory, it is not necessarily the dominant organism in acid rock wastes or in engineered bioleaching systems (Schrenk et al., 1998). Therefore, the relative importance of the direct and indirect mechanisms may depend on the particular microbial community and geochemical conditions.

Biological reduction of $\mathrm{U}(\mathrm{VI})$ has been extensively studied because of its potential for use in engineered bioremediation of U-contaminated groundwater. Microorganisms with the ability to enzymatically reduce $\mathrm{U}(\mathrm{VI})$ are phylogenetically diverse and span a wide range of environmental temperature, $\mathrm{pH}$, and metabolic niches (Suzuki and Suko, 2006; Wall and Krumholz, 2006). Metaland sulfate-reducing bacteria, including Geobacter, Shewanella, and Desulfovibrio species, have been a primary focus of $U$ reduction research because of their prevalence in the environment as well as their ability to be cultured in the laboratory (Lovley et al., 1991; Gorby and Lovley, 1992; Lovley and Phillips, 1992). Enzymatic $\mathrm{U}(\mathrm{VI})$ reduction can be a dissimilatory process, resulting in cell growth. However, because $U$ is not an essential nutrient, there are no known dedicated $\mathrm{U}(\mathrm{VI})$ reducing enzymes (Suzuki and Suko, 
2006). A $c_{3}$ cytochrome pathway has been identified as a key component of the electron transport chain involved with $\mathrm{U}(\mathrm{VI})$ reduction in Desulfovibrio, Shewanella, and Geobacter species (Lovley et al., 1993; Shelobolina et al., 2007; Orellana et al., 2013). Interestingly, when the target $c_{3}$ cytochrome was removed in a mutant Shewanella strain, $\mathrm{U}(\mathrm{VI})$ reduction was decreased but not eliminated, suggesting that the $U$ reductases are non-specific and may be shared with other processes such as $\mathrm{Fe}(\mathrm{III})$ reduction; there appear to be redundant pathways for $U$ electron transfer (Payne et al., 2002; Mehta et al., 2005). It is also possible that electrons are transferred fortuitously to $\mathrm{U}(\mathrm{VI})$ by an electron transport chain activated for an alternate electron acceptor, such as Fe(III). The location of these U-active cytochromes is most likely on the outside of the cytoplasmic membrane, the outer membrane, and/or in the periplasm (Wall and Krumholz, 2006). Biochemical evidence suggests that the reductase transfers one electron to form $U(V)$, which then disproportionates to $\mathrm{U}(\mathrm{VI})$ and $\mathrm{U}(\mathrm{IV})$, rather than executing a two electron transfer (Renshaw et al., 2005; Großmann et al., 2007). An additional pathway for microbial $\mathrm{U}(\mathrm{VI})$ reduction has been observed in Geobacter species, utilizing extracelluar conductive pili (Cologgi et al., 2011; Reguera, 2012). This pathway enhanced the rate and extent of $U$ reduction per cell and prevented accumulation of reduced $U$ minerals inside the cell, protecting the cell's viability.

The sequence of microbially mediated redox processes in sediments is generally ordered from highest to lowest reduction potential: $\mathrm{O}_{2}, \mathrm{NO}_{3}^{-}, \mathrm{Mn}^{\mathrm{IV}}, \mathrm{Fe}^{\mathrm{III}}, \mathrm{SO}_{4}^{2-}$. The $\mathrm{U}(\mathrm{VI}) / \mathrm{U}(\mathrm{IV})$ redox couple has a similar potential to the $\mathrm{Fe}(\mathrm{OH})_{3} / \mathrm{Fe}$ (II) couple, and is sensitive to aqueous speciation (Fig. 2). Uranium(VI) aqueous speciation also affects the bioavailability for microbial reduction. Most metalreducing bacteria appear to be able to reduce carbonate-complexed U (Phillips et al., 1995), but the uranyl-carbonate complexes and organic-U complexes may pose a limitation for several sulfatereducing bacterial strains, even though the mechanism of this inhibition is not well understood (Ganesh et al., 1997; Suzuki and Suko, 2006; Wall and Krumholz, 2006). In a laboratory study with Shewanella oneidensis, increasing $\mathrm{NaHCO}_{3}$ concentrations resulted in slower U(VI) reduction kinetics (Sheng and Fein, 2014). In addition, the presence of Ca-uranyl-carbonate ternary complexes may decrease the rate and extent of $\mathrm{U}(\mathrm{VI})$ reduction by Shewanella, Geobacter, and Desulfovibrio species, but it does not completely inhibit the microbial metabolism (Brooks et al., 2003). The reaction kinetics of reduction of uranyl-carbonate and Ca-uranyl-carbonate ternary species by Shewanella oneidensis can vary substantially, showing an inverse correlation to carbonate and Ca concentrations and a strong pH dependence (Ulrich et al., 2011). In a field setting, the rates of microbial reduction will be strongly dependent on the geochemical conditions (e.g., $\mathrm{pH}$, mineral dissolution and precipitation), aqueous $\mathrm{U}(\mathrm{VI})$ speciation, and the active microbial population.

In laboratory culture, the product of $\mathrm{U}(\mathrm{VI})$ reduction is often a black precipitate identified as uraninite, or $\mathrm{UO}_{2(\mathrm{~s})}$, also referred to as biogenic uraninite. Although first observed with Geobacter metallireducens, uraninite forms in cultures of a variety of diverse organisms (Gorby and Lovley, 1992; Suzuki et al., 2002; Sharp et al., 2009). The precipitate is generally formed in the periplasm or externally to the cell, and may be associated with or near reductase cytochromes and exopolymeric substances (Marshall et al., 2006). Biogenic uraninite is nanoparticulate $(2-10 \mathrm{~nm})$, exhibiting a contraction of the $\mathrm{U}$ lattice compared with synthetic bulk $\mathrm{UO}_{2}$ because of the large number of $U$ atoms on the surface of the nanoparticle (approximately 50\% of $U$ atoms), whereas the core of the particle remains highly ordered stoichiometric $\mathrm{UO}_{2}$ (Burgos et al., 2008; Schofield et al., 2008; Singer et al., 2009). The surface of the particle is slightly more disordered than the interior, but it is still essentially crystalline and stoichiometric, based on detailed
X-ray absorption and synchrotron powder diffraction studies (Schofield et al., 2008; Bargar et al., 2009). The nanoparticulate product of some bacterial species tend to form larger aggregates, and the size of the particles and aggregates correlated directly with rates of $\mathrm{U}(\mathrm{VI})$ reduction; faster reduction rates produced smaller and less aggregated particles in incubations with Shewanella putrefaciens. However, this effect was not observed with incubations of Shewanella oneidensis, indicating that particle size and reduction rate are not universally correlated and particle size alone cannot be used to infer rates of reduction (Burgos et al., 2002; Senko et al., 2007).

Recent data have indicated that uraninite is not the only possible reduced U(IV) phase resulting from microbial activity. Uraninite has been directly observed at several field locations where microbial activity was stimulated, but more often it is inferred to be the reaction product of biological $\mathrm{U}(\mathrm{VI})$ reduction because it is the product of pure culture precipitation from dissolved $U(V I)$ in the laboratory. An extended X-ray absorption fine structure (EXAFS) study of naturally-occurring reduced sediment from the Old Rifle, CO, UMT site shows a strong U-O shell, but a complete lack of the U-U shell characteristic of uraninite (Campbell et al., 2011a). There is evidence that an adsorbed, biomass-associated, or poorly structured $\mathrm{U}(\mathrm{IV})$ phase is possible (Bernier-Latmani et al., 2010; Fletcher et al., 2010). A non-uraninite U(IV) phase also has been observed in abiotic $\mathrm{U}(\mathrm{VI})$ reduction in green rust and Fe(II)-containing clay systems (Chakraborty et al., 2010; Latta et al., 2012a, 2012b). The formation of a monomeric or molecular (non-uraninite) $\mathrm{U}(\mathrm{IV})$ phase appears to be linked to the presence of phosphate, whether it is in biomass, adsorbed on surfaces, or found in a mineral (e.g., vivianite) (Bernier-Latmani et al., 2010; Sharp et al., 2011; Veeramani et al., 2011). In a study of U(IV) products produced by seven strains of bacteria as well as a chemical reductant (9,10-anthrahydroquinone-2,6-disulfonate, AQDS), Boyanov et al. (2011) found that several strains of bacteria produced uraninite in phosphate-free medium, but non-uraninite $\mathrm{U}(\mathrm{IV})$ was the product in phosphate-amended medium. In addition, the abiotic reduction experiments with AQDS also exhibited a similar phosphate-controlled difference in products. Dissolved sulfate and silicate may also promote the formation of non-uraninite U(IV) (Stylo et al., 2013). Mixtures of biogenic uraninite and monomeric U(IV) have been observed in bioreduced sediments (Sharp et al., 2011; Bargar et al., 2013), and laboratory studies indicate that non-uraninite U(IV) is slightly more susceptible to oxidation than biogenic uraninite in the presence of dissolved oxygen (Cerrato et al., 2013).

\subsection{Abiotic $U$ redox behavior}

Oxidation of U(IV) at circumneutral pH is generally considered to be dominated by abiotic oxidizing processes. Dissolved oxygen, nitrate, and solid phases such as Fe- and Mn-oxides are important oxidants of reduced $U$ phases. Peroxide compounds and other reactive oxygen species generated from radioactive decay are also oxidants, but only form in appreciable concentrations in intermediate-to-high level radioactive wastes, which is beyond the scope of this review. However, some related research has been presented on $U$ redox fronts and oxidation in the high-level radioactive waste repository literature, particularly on natural analogs (e.g., Miller et al., 1994). The discussion presented in this paper will focus on oxidation of biogenic uraninite because of the wealth of recent literature on the topic because of its importance to bioremediation research.

Biotic oxidation of $\mathrm{U}(\mathrm{IV})$ at circumneutral $\mathrm{pH}$ may be important under certain circumstances, and abiotic oxidative processes are generally kinetically favorable. There has been some debate in the literature about whether the nanoparticulate nature of 
biogenic $\mathrm{UO}_{2}$ should substantially increase the solubility (Suzuki et al., 2002) or whether the stoichiometry and lack of significant lattice strain implies a thermodynamically similar solubility to bulk $\mathrm{UO}_{2}$ (Bargar et al., 2008). In flow-through experiments comparing biogenic $\mathrm{UO}_{2}$ to synthetic bulk $\mathrm{UO}_{2}$, surface-area normalized rates of oxidation were similar (Ulrich et al., 2008, 2009), and although larger surface areas resulted in increased oxidation rates, aggregation may play an important role in mitigating the effects of particle size in oxidation rates and mobility (Senko et al., 2007; Bargar et al., 2008). In addition, dopants in the biogenic $\mathrm{UO}_{2}$ structure may alter its solubility similar to the observed decreased solubility of natural uraninite (non-stoichiometric $\mathrm{UO}_{2+\mathrm{x}}$ with possible Th, Ca, or rare earth elements (REE) as impurities) compared to stoichiometric synthetic $\mathrm{UO}_{2.0}$ (Finch and Ewing, 1992). The structure of $\mathrm{UO}_{2}$ generally allows for additional oxygen atoms and cation incorporation into its composition because of its open fluorite crystal structure (Bargar et al., 2008). In a study of biogenic $\mathrm{UO}_{2}$ doped with $\mathrm{Mn}(\mathrm{II})$, the equilibrium solubility was half that of conventional biogenic $\mathrm{UO}_{2}$ and the rate of oxidation by dissolved $\mathrm{O}_{2}$ was 38 times slower (Veeramani et al., 2009). This observation suggests that environmentally relevant cations incorporated into the biogenic $\mathrm{UO}_{2}$ structure may have a stabilizing effect by decreasing the solubility and susceptibility to oxidation; further research into the effect of additional cations is needed.

Numerous laboratory studies with both pure biogenic $\mathrm{UO}_{2}$ and reduced sediment have observed oxidation of $\mathrm{U}(\mathrm{IV})$ by oxygen, nitrate and denitrification intermediates $\left(\mathrm{NO}_{2}^{-}, \mathrm{NO}, \mathrm{N}_{2} \mathrm{O}\right)$, and Fe(III) (e.g., Ginder-Vogel et al., 2006; Komlos et al., 2007, 2008a; Wu et al., 2007; Moon et al., 2009; Sharp et al., 2011). The presence of dissolved oxygen and inorganic carbon substantially accelerated the rates of dissolution compared to the absence of either dissolved inorganic carbon or oxygen. Because carbonate is a strong complexing agent for $\mathrm{U}(\mathrm{VI})$, it quickly removes oxidized $\mathrm{U}$ from the surface of the particle that would otherwise accumulate and slow the oxidative progress. Because carbonate is present in most natural waters, the rate-limiting step is most likely the oxidation of U(IV) to $\mathrm{U}(\mathrm{VI})$, not the accumulation of oxidation products on the solid surface. Under the appropriate conditions, secondary mineral precipitation may shield the uraninite from oxidation. The presence of dissolved $\mathrm{Ca}^{2+}, \mathrm{Zn}^{2+}$, and $\mathrm{Mn}^{2+}$ (under anoxic conditions) has been shown to substantially lower the dissolution of biogenic uraninite by coating the uraninite surface with a metal-carbonate precipitate (Cerrato et al., 2012; Wang et al., 2014), although Mn(II) redox cycling can promote uraninite dissolution in the presence of dissolved oxygen (Wang et al., 2014) or impede U(IV) precipitation (Fredrickson et al., 2002). In situ rates of uraninite corrosion by groundwater in oxic and suboxic conditions, but in the absence of solid phase oxidants, have been found to be several orders of magnitude slower than predicted by laboratory studies, possibly due to stabilizing cations or diffusion effects (Campbell et al., 2011b), suggesting that biogenic uraninite may be more stable in contact with groundwater than originally thought. Sediment column studies suggest, however, that sediment-associated non-uraninite U(IV) may be more easily oxidized by dissolved oxygen than biogenic uraninite (Sharp et al., 2011).

Although introduction of oxygen or nitrate is often considered the most common oxidative process, $\mathrm{UO}_{2}$ oxidation is also possible by solid-phase oxidants such as $\mathrm{Mn}$ - and Fe-oxides, even under anaerobic conditions. Iron(III) oxides in particular may play an important role in reoxidation of U(IV) under the appropriate conditions. Because $U$ and Fe redox couples occur at similar potentials, small changes in geochemical conditions may change the favorability of $\mathrm{U}(\mathrm{IV})$ oxidation, and conversely, $\mathrm{U}(\mathrm{VI})$ reduction (Fig. 2, Ginder-Vogel et al., 2006). A direct solid-solid electron transfer is unlikely to occur, but the process is hypothesized to proceed by (1) slight dissolution of $\mathrm{UO}_{2}$, a sparingly soluble solid, (2) adsorption onto the Fe(III) solid surface, (3) electron transfer, and (4) desorption of $\mathrm{U}(\mathrm{VI})$ reaction products from the surface in the presence of bicarbonate (Ginder-Vogel et al., 2010). A similar reaction may take place between biogenic uraninite and $\mathrm{MnO}_{2(\mathrm{~s})}$, where close proximity of the solids was necessary to observe U(IV) oxidation (Wang et al., 2013).

Iron(II) is one of the most environmentally important reducing agents because it is commonly found dissolved in natural waters, adsorbed to mineral surfaces, and structurally incorporated in mineral structures. Abiotic reduction of aqueous $\mathrm{U}(\mathrm{VI})$ by aqueous $\mathrm{Fe}(\mathrm{II})$ is thermodynamically feasible but kinetically limited and is not likely to be an important pathway at circumneutral $\mathrm{pH}$ (Charlet et al., 1998; Liger et al., 1999). However, electron transfer between $\mathrm{Fe}(\mathrm{II})$ and metal ions can be enhanced by adsorption and/ or incorporation onto a mineral surface (Wehrli et al., 1989). In several experiments performed in the absence of dissolved inorganic carbon, $\mathrm{Fe}(\mathrm{II})$ that was adsorbed onto hematite and ferrihydrite reduced adsorbed $\mathrm{U}(\mathrm{VI})$ to $\mathrm{U}(\mathrm{IV})$ via an inner-sphere electron transfer, possibly involving a $\mathrm{U}(\mathrm{V})$ intermediate (Charlet et al., 1998; Liger et al., 1999; Jang et al., 2008). Under similar conditions with $\mathrm{U}(\mathrm{VI})$ - and $\mathrm{Fe}(\mathrm{II})$-reacted ferrihydrite, the solid phase transformed to goethite, and $\mathrm{U}(\mathrm{VI})$ and $\mathrm{U}(\mathrm{V})$ were found to be incorporated into the goethite crystal structure, making $U$ less likely to be mobilized back into solution (Boland et al., 2011). Computational ( $a b$ initio molecular orbital calculations) and experimental results from Skomurski et al. (2011) demonstrated that the stability field of $U(V)$ was widened when $U(V I)$ was reduced on a magnetite surface, providing insight into a potential molecular explanation for the presence of the relatively rare $U(V)$ species. When $\mathrm{U}(\mathrm{VI})$ was reacted with $\mathrm{Fe}(\mathrm{II})$ on a non-conductive solid phase, such as silica or aluminum oxide, a critical sorption density of $\mathrm{Fe}(\mathrm{II})$ and $\mathrm{U}(\mathrm{VI})$ had to be reached before direct two electron transfer could take place to produce U(IV) (Boyanov et al., 2007). It is possible that Fe oxides or other conductive minerals may be particularly important in the environment because of the ability to conduct electrons through the bulk of the mineral (Williams and Scherer, 2004), allowing for electron transfer to take place even when the $\mathrm{Fe}(\mathrm{II})$ and $\mathrm{U}(\mathrm{VI})$ molecules are not in immediate proximity.

Inorganic carbon is also important in $\mathrm{Fe}(\mathrm{II})-\mathrm{U}(\mathrm{VI})$ systems, where sorption affinity and aqueous $\mathrm{U}(\mathrm{VI})$ speciation are controlled by dissolved $\mathrm{CO}_{2}$. The presence of bicarbonate significantly slowed the abiotic reduction of $\mathrm{U}(\mathrm{VI})$ by $\mathrm{Fe}(\mathrm{II})$ adsorbed on hematite because of the increased aqueous complexation of $\mathrm{U}(\mathrm{VI})$ by uranyl-carbonate complexes, resulting in decreased surface adsorption (Behrends and Van Cappellen, 2005). A separate study with magnetite and corundum corroborated the observation that the total amount of $U$ sequestered onto the solid phase decreased in the presence of bicarbonate, but found that the fractional amount of adsorbed $\mathrm{U}(\mathrm{VI})$ reduced to $\mathrm{U}(\mathrm{IV})$ increased, presumably due to increased reactivity of a uranyl-surface-carbonate ternary complex (Regenspurg et al., 2009).

Ferrous iron-containing solid phases, such as magnetite $\left(\mathrm{Fe}_{3} \mathrm{O}_{4}\right)$, green rusts [mixed $\mathrm{Fe}(\mathrm{II})-\mathrm{Fe}(\mathrm{III})$ layer hydroxides], and $\mathrm{Fe}(\mathrm{II})$-rich clays also have been shown to serve as effective reductants for adsorbed $\mathrm{U}(\mathrm{VI})$. Many $\mathrm{Fe}(\mathrm{III})$ oxides tend to recrystallize into mixed $\mathrm{Fe}(\mathrm{II})-\mathrm{Fe}(\mathrm{III})$ phases in the presence of $\mathrm{Fe}(\mathrm{II})$; the minerals formed depends on the $\mathrm{Fe}(\mathrm{II})$ concentration as well as the presence of other ions (e.g., chloride, silicate, sulfate, and bicarbonate). Sulfate green rust is particularly effective with near-complete reduction of $U(V I)$ to U(IV) at neutral pH (Dodge et al., 2002; O'Loughlin et al., 2003). Magnetite can also serve as a reductant, although it is most effective at moderately low $\mathrm{pH}(\mathrm{pH} 4-5)$. Uranium(VI) reduction is sensitive to the magnetite $\mathrm{Fe}(\mathrm{II})$ stoichiometry and can be inhibited by the presence of $\mathrm{U}(\mathrm{VI})-\mathrm{Ca}$-carbonate surface complexes (Missana et al., 2003; O'Loughlin et al., 2010; Latta et al., 2012a, 2012b; 
Singer et al., 2012). Thus, secondary mineral transformation may control the rate and extent of abiotic $\mathrm{U}(\mathrm{VI})$ reduction during sediment diagenesis or other processes producing $\mathrm{Fe}(\mathrm{II})$.

Besides Fe oxides, Fe(II)-containing clay minerals are common in many soils and sediments. When U diffuses into clay interlayers, electron transfer with Fe(II) can occur (Ilton et al., 2004, 2006). Uranium(VI) reduction has been observed even in the presence of dissolved oxygen, suggesting that $U$ reduced in clay interlayers can be isolated from oxidizing conditions in the bulk solution. Even when $\mathrm{Fe}(\mathrm{II})$ was simply adsorbed onto Ca-montmorillonite [no structural $\mathrm{Fe}(\mathrm{II})$ ] under $\mathrm{CO}_{2}$-free conditions, $\mathrm{U}(\mathrm{VI})$ reduction was observed (Chakraborty et al., 2010). The efficacy of green rusts and/or Fe(II)-bearing clays in pasteurized, natural soil was demonstrated in Latta et al. (2012a, 2012b), in which approximately 50\% of the $\mathrm{U}(\mathrm{VI})$ was reduced abiotically to $\mathrm{U}(\mathrm{IV})$. Although other studies using Fe(II)-containing, natural soil that was treated with heat to kill microbes have not observed $\mathrm{U}(\mathrm{VI})$ reduction (e.g., Liu et al., 2005; Finneran et al., 2002), these results suggest that Fe(II) mineralogy plays a critical role in abiotic $U$ reduction. In general, the ability of solid-phase $\mathrm{Fe}(\mathrm{II})$ to reduce $\mathrm{U}(\mathrm{VI})$ depends on the aqueous geochemical conditions (e.g., $\mathrm{pH}, p \mathrm{CO}_{2}$ ), solid phases present, and concentrations of reactants.

Under sulfate-reducing conditions, dissolved sulfide and metal sulfide precipitates are commonly formed. Like dissolved $\mathrm{Fe}(\mathrm{II})$, dissolved sulfide has the thermodynamic potential to reduce dissolved $\mathrm{U}(\mathrm{VI})$, but is often kinetically limited at concentrations found in the environment (Anderson, 1987; Kochenov et al., 1977; Mohagheghi and Goldhaber, 1982). Sulfide phases, including pyrite $\left(\mathrm{FeS}_{2}\right)$, amorphous $\mathrm{FeS}$, and other metal sulfides such as galena $(\mathrm{PbS})$, can act as reducing agents for adsorbed $\mathrm{U}(\mathrm{VI})$ (Wersin et al., 1994; Hua and Deng, 2008; Hyun et al., 2012; Gallegos et al., 2013). Sulfide minerals play an additional role in $U$ redox chemistry: they can poise the redox conditions by preventing, or at least delaying, the oxidation of $U(I V)$ in the presence of an aqueous oxidant by scavenging the oxidant. This process has been shown for $\mathrm{Fe}(\mathrm{II})$-sulfide phases in microcosm and column studies with sediment from a UMT site in Tuba City, Arizona (Abdelouas et al., 1999). Reducing conditions were created in the sediment, allowing U(IV) and mackinawite $\left(\mathrm{Fe}_{1+x} \mathrm{~S}\right.$, where $x=0$ 0.11 ) to precipitate. The sediments were then reoxidized with oxic groundwater from the site. The mackinawite initially protected the reduced $U(I V)$ from reoxidation. Whereas reduction of $U$ by sulfides alone may be inhibited by carbonate and bicarbonate in groundwater (Abdelouas et al., 1998a), mackinawite is thought to buffer redox conditions such that reoxidation of the U(IV) solid will be mitigated (Abdelouas et al., 1998b, 1999). The dual role of Fesulfides as reductant and poising agent has been demonstrated in a study in which $\mathrm{U}(\mathrm{VI})$ was reduced to uraninite when adsorbed onto synthetic mackinawite under $\mathrm{CO}_{2}$-free conditions over a range of $\mathrm{pH}$ values (5-11) (Hyun et al., 2012). When oxygen was introduced into the system, the mackinawite provided an effective redox buffer against $\mathrm{U}(\mathrm{IV})$ oxidation and re-mobilization into solution. In addition, when iron sulfide phases eventually oxidize, iron oxides are produced, which can act as a sorptive surface for $\mathrm{U}(\mathrm{VI})$ (Gallegos et al., 2013).

\subsection{Effect of natural organic matter on redox processes}

The structural complexity of natural organic matter (NOM) makes its redox function in the environment multifaceted and difficult to study and quantify. Much of this complexity is driven by the diversity of functional groups, reactivity, and molecular size of NOM. Humic acids (HA) and fulvic acids (FA) are generally used as model organic compounds because of their relatively high level of characterization and prevalence in the environment. Generally, $\mathrm{U}$ has a strong binding affinity for NOM, both soluble and insoluble fractions. Soluble HA can complex U(VI), increasing its solubility and reducing its ability to adsorb onto Fe oxides and clays at circumneutral pH (Křepelová et al., 2006). Natural organic matter can also affect the rate and extent of $U$ sorption onto silica sand (Tinnacher et al., 2013). The increased solubility of $\mathrm{U}(\mathrm{VI})$ in the presence of HA also may impair reduction to U(IV) by solid phase $\mathrm{Fe}(\mathrm{II})$. Complexation of $\mathrm{U}(\mathrm{VI})$ with $\mathrm{HA}$ is strongest between $\mathrm{pH}$ 4.5 and 7 in the presence of dissolved inorganic carbon $\left(p \mathrm{CO}_{2}\right.$ at least $\left.10^{-3.5} \mathrm{~atm}\right)$. At low and high $\mathrm{pH}(<3$ or $>8.5$ ), HA can increase adsorption to mineral surfaces, possibly due to low solubility of HA at low $\mathrm{pH}$ and the presence of $\mathrm{U}(\mathrm{VI})$-carbonate-HA ternary surface complexes at high pH (Lenhart and Honeyman, 1999; Křepelová et al., 2006; Payne et al., 1996). The presence of HA can affect $\mathrm{U}(\mathrm{IV})$ as well by increasing the solubility via the formation of aqueous U(IV)-HA species; increased rate of oxidation has been observed due to this complexation (Gu et al., 2005).

The effect of NOM on microbial $\mathrm{U}(\mathrm{VI})$ reduction is mixed, and may depend on the particular species of organism present. Humic acids can either stimulate microbial $U$ reduction by acting as an electron donor or suppress it by making the $\mathrm{U}(\mathrm{VI})$ biologically unavailable (Gu and Chen, 2003; Gu et al., 2005; Burgos et al., 2007). Some NOM has been shown to act as an electron shuttle, similar to bio-organic compounds such as the quinone-containing molecules produced by bacteria (Lovley et al., 1996). It has been hypothesized that NOM can be incorporated into the electron transport cycle of bacteria capable of $\mathrm{U}(\mathrm{VI})$ reduction, although this has not been demonstrated conclusively (Fredrickson et al., 2000). The specific interactions of organic matter, U, bacteria, and solid phases are complex, and further research is needed to more completely understand these interactions.

Because of the affinity of $U$ for organic matter, the probable ability of some bacteria to use NOM as an electron donor for U(VI) reduction, and the lower solubility of reduced $U$, $U$ tends to accumulate in wetlands, peat deposits, and other organic-rich, reducing formations. For example, $U$ has been naturally leached from disperse sandstone deposits in Scotland and has accumulated in a peat bog to concentrations greater than $1000 \mathrm{mg} / \mathrm{kg}$ (Read et al., 1993). Wetlands have also been explored as potential filters for dissolved $U$. This possibility has been investigated in a study by the USGS of beaver ponds in the western US, where decaying organic matter accumulated up to $1 \times 10^{4} \mathrm{mg} / \mathrm{kg} \mathrm{U}$ from weathering of local granites or rhyolites (Owen and Otton, 1995). In addition, an organic-rich soil in Switzerland was found to have accumulated $U$ from surrounding source rock to concentrations up to $4000 \mathrm{mg} / \mathrm{kg}$, with $\mathrm{U}$ occurring as a mixture of $\mathrm{U}(\mathrm{VI})$ and $\mathrm{U}(\mathrm{IV})$ in the soil, suggesting that both complexation and reductive processes were important in $U$ sequestration (Regenspurg et al., 2010). The recognition of accumulation of $U$ in organic-rich bogs or soil not only helps to elucidate processes operative in the early stages of U-rich lignite or carbonaceous shale formation, but also can identify economically viable deposits. One such young, organic-rich, surficial U deposit has been mined during the 1980s at Flodelle Creek in Washington state (Zielinski and Meier, 1988).

Peat bogs and wetlands have been explored as candidates for accumulation of $U$ and other metals by natural attenuation. However, it is important to note that changing the oxidation state of the wetland (e.g., oxidation during seasonal drying or harvesting) may remobilize $U$, and that acid inputs or acid sources of $U$ may not be suitable for healthy wetland maintenance. This oxidation issue is illustrated by an example from shallow ponds in South Africa, where flow of waters with enriched concentrations of $U$ from a $\mathrm{Au}$ and $U$ tailings impoundment seepage accumulated $U$ in fluvial sediments. In dammed reaches of the Wonderfontein Spruit (meaning the "miraculous fountain stream"), the organic-rich sediment collected in farm ponds downstream of the two goldfields and their extraction plants had $U$ concentrations of several 
hundred $\mathrm{mg} / \mathrm{kg}$, well in excess of most tailings in the area (Winde, 2010). Around 2002, a farmer drained one of these shallow ponds to extract residual Au that had accumulated along with the U. The impact of such practices on remobilization of $U$ by oxidation should be evaluated.

\subsection{Non-redox bacterial $U$ accumulation}

Microbial and fungal cell components can serve as binding sites for $U$, either on extracellular material or on the surface of cells, live or dead. Biomass can accumulate substantial amounts of $U$, although the capacity differs greatly among organisms. The mechanisms of biosorption will not be discussed in detail here, as this topic has been reviewed in detail by Suzuki and Banfield (1999).

Certain organisms may actively accumulate $\mathrm{U}(\mathrm{VI})$ intracellularly. For example, studies in U mines (Updegraff and Douros, 1972) and in UMT (Miller et al., 1987) showed a remarkable abundance of Arthrobacter, a strict anaerobe (Buchanan and Gibbons, 1974). Suzuki and Banfield (2004) isolated a bacterium from acidic sediments at the Midnite Mine in eastern Washington that was able to grow in a $\mathrm{pH} 4$ solution containing $80 \mathrm{mg} / \mathrm{L}$ of $\mathrm{U}(\mathrm{VI})$. This isolate was closely related to Arthrobacter ilicis, and accumulated $\mathrm{U}(\mathrm{VI})$ intracellularly as precipitates closely associated with polyphosphate granules. Such sequestration of $U$ into polyphosphate may represent a detoxification mechanism. Similarly, Geißler (2007) has demonstrated the precipitation of intracellular U(VI) as crystals of a uranyl phosphate compound by an Arthrobacter species isolated from $U$ mining wastes.

Merroun and Selenska-Pobell (2008) have documented the precipitation of vaterite (a polymorph of calcite) by Arthrobacter; such bacterially mediated formation of carbonate minerals may have the potential to coprecipitate $\mathrm{U}$ and $\mathrm{Ra}$ at $\mathrm{U}$ mining and milling sites (Landa, 2004). For more details on U substitution in carbonates, see Landa (2004, section 2.4). Arthrobacter also may play a role in the precipitation of Mn oxides, and the resultant sorption of a large fraction of the dissolved ${ }^{226} \mathrm{Ra}$ in UMT ponds (Mathur and Dwivedy, 1988). Further studies aimed at the development of remediation strategies based upon Arthrobacter-mediated biomineralization appear justified. By analogy to $U$ and Ra, these bioremediation trials also might include transuranic elements and alkaline-earth fission products (such as ${ }^{90} \mathrm{Sr}$ ) associated with the back end of the nuclear fuel cycle.

\section{Uranium mining and milling}

\subsection{Ore bodies and mineralogy}

The geology of $U$ ore formation has been studied extensively, and will briefly be summarized here. Along with many other economically important elements, $U$ generally is enriched in the crust compared to the upper mantle, with an average crustal abundance of $2.6 \mathrm{mg} / \mathrm{kg}$, and tends to be more concentrated in silicic and alkaline intrusive igneous rocks and relatively low in mafic rocks (Plant et al., 1999). Weathering and metamorphism can concentrate $U$ further; crustal processes dominate $U$ enrichment and formation of ore-grade deposits (Plant et al., 1999). Ores are often formed from elevated concentrations found in residuals resulting from igneous cooling and crystallization or from water coming in contact with these residuals (Wanty et al., 1999). The International Atomic Energy Agency (IAEA) has classified and ranked $U$ ore deposits into 14 categories based on geological setting and economic significance. A general description of each type of deposit is given in Table 1 (IAEA, 2009b).

The predominant uraniferous minerals in an ore body depends on the geologic setting in which the deposit formed, although the most common U mineral in economically important ore deposits is uraninite (stoichiometrically represented as $\mathrm{UO}_{2.0}$ ) (Finch and Murakami, 1999). Coffinite $\left(\mathrm{USiO}_{4} \cdot n \mathrm{H}_{2} \mathrm{O}\right)$ and brannerite $\left[\mathrm{U}(\mathrm{Ti}, \mathrm{Fe})_{2} \mathrm{O}_{6}\right]$ are also common minerals in ore deposits, along with various alteration products of these minerals. In natural formations, it is commonly observed that these minerals may contain trace amounts of other elements (e.g., $\mathrm{Pb}, \mathrm{Ca}$, Th, and Y) (Finch and Murakami, 1999). Uranium can form solid solutions with Ceand $\mathrm{Zr}$-containing minerals, and may cause metamictization when present in high concentrations (Plant et al., 1999). Various U(VI) minerals, such as uranyl oxyhydroxides, come from oxidation of $\mathrm{U}(\mathrm{IV})$ under transitional redox conditions. Uranyl carbonates, silicates, sulfates, phosphates, and arsenates can form, leading to the natural occurrence of nearly $200 \mathrm{U}$-containing minerals. Uranium(VI) also can accumulate to substantial concentrations

Table 1

General description of U ore deposits, as classified by the IAEA (Dahlkamp, 1993; Plant et al., 1999; IAEA, 2009b; Otton et al., 2010).

\begin{tabular}{|c|c|c|c|}
\hline $\begin{array}{l}\text { Economic } \\
\text { rank }\end{array}$ & Deposit name & General geological description & Examples/selected locations \\
\hline 1 & $\begin{array}{l}\text { Unconformity } \\
\text { related }\end{array}$ & $\begin{array}{l}\text { Sediment covering over basement complexes. U accumulation in faults and fractures from } \\
\text { metamorphosis, weathering, and hydrothermal alteration }\end{array}$ & $\begin{array}{l}\text { - Athabasca Basin, Canada } \\
\text { - McArthur Basin, Australia }\end{array}$ \\
\hline 2 & Sandstone & $\begin{array}{l}\text { Sandstones from continental fluvial or marginal marine deposits. U accumulation from } \\
\text { oxidation/reduction transformations }\end{array}$ & $\begin{array}{l}\text { - Roll-front deposits, Rocky } \\
\text { Mountain region, USA (Fig. 3) }\end{array}$ \\
\hline 3 & $\begin{array}{l}\text { Quartz-pebble } \\
\text { conglomerate }\end{array}$ & $\begin{array}{l}\mathrm{U} \text { deposition in fluvial sedimentary environment from igneous source rock; } \mathrm{U} \text { accumulation } \\
\text { during microbial sulfate reduction may be important }\end{array}$ & $\begin{array}{l}\text { - Elliot Lake, Canada } \\
\text { - Witwatersrand, South Africa }\end{array}$ \\
\hline 4 & Breccia complex & $\begin{array}{l}\text { U deposition from alterations (e.g., hydrothermal); can commonly co-occur with other } \\
\text { elements ( } \mathrm{Cu}, \mathrm{Fe}, \mathrm{REE})\end{array}$ & - Olympic Dam, Australia \\
\hline 5 & Veins & $\mathrm{U}$ mineralization in fractures and cavities in granitic rocks & - Czech Republic, Germany, France \\
\hline 6 & Intrusive & Intrusion of uraniferous magmas, mainly alkaline granites, pegmatites & $\begin{array}{l}\text { - Ilimaussaq, Greenland } \\
\text { - Palabora, South Africa }\end{array}$ \\
\hline 7 & Phosphorite & Marine sedimentary deposits rich in U-associated apatite and fluorapatite & - Florida and Idaho, USA \\
\hline 8 & $\begin{array}{l}\text { Collapse breccia } \\
\text { pipe }\end{array}$ & U deposits in coatings and cavities in vertical collapse structures & - Arizona, USA \\
\hline 9 & Volcanic & U associated with felsic volcanic rocks and associated sediments & $\begin{array}{l}\text { - McDermitt (Nevada), USA } \\
\text { - Pleutajokk, Sweden }\end{array}$ \\
\hline 10 & Surficial & $\begin{array}{l}\text { U mainly associated with calcretes or peat bog deposits in unconsolidated near-surface } \\
\text { sediments }\end{array}$ & - Australia, Namibia, Somalia \\
\hline 11 & Metasomatite & Result of Na-rich-fluid/rock interaction and albitization of uraniferous granite & - Ukraine, Russia \\
\hline 12 & $\begin{array}{l}\text { General } \\
\text { metamorphic }\end{array}$ & Metamorphosis of U-containing granites or sediments & - Australia \\
\hline 13 & Lignite & $\mathrm{U}$ adsorption onto lignite deposits & - North and South Dakota, USA \\
\hline 14 & Black shale & U association with organic-rich sediments & - Ranstad, Sweden \\
\hline
\end{tabular}


through adsorption to organic matter, as is the case of lignite and shale deposits. For a detailed discussion of $U$ mineralogy, the reader is directed to the review article by Finch and Murakami (1999).

\subsection{Heap leaching and bioleaching}

Heap leaching refers to a technique in which low-grade ore is crushed and placed above a leachate collection/containment system. Either in situ reactions (typically bacterial oxidation of sulfide minerals in the ore to generate sulfuric acid rich in ferric iron; "bioleaching") or added reagents, plus sprinkler-applied water, are used to mobilize the economic constituent and transport it to a concentration circuit. Heap leaching has had widespread use in the recovery of $\mathrm{Cu}$ and Au. Recovery of $\mathrm{U}$ from ore and tailings also is possible, and recent literature (Jianguo et al., 2004) indicates that it is used at two or more sites in China.

Leaching is typically a surface operation done on an impervious pad, but McCready and Gould (1990) describe pilot-scale bioleaching tests done in underground $U$ mines in Canada in the 1970s1980 s. Of particular interest are mid-late 1980s studies involving the periodic flooding of blasted ore in underground stopes of the Denison Mine at Elliot Lake, Ontario. Experimental interest focused on optimization of growth of an indigenous isolate of Acidithiobacillus ferrooxidans. Perforated, compressed air lines were installed on the floor of the test stope prior to ore blasting from the roof of the stope. The drilling pattern for blasting was done to optimize ore fragmentation to increase surface area of ore particles. With repeated flooding cycles and removal of acid-soluble and acid-generating minerals, the texture of the pile became finer. This further increased surface area, but also limited oxygen diffusion to bacteria in the resultant muck.

The explosives provided excess nitrogen, and the earth materials in the flow path appeared to provide an adequate soluble supply of most other nutrients, including carbon. However, laboratory tests showed the mine water was likely deficient in phosphate. Phosphoric acid was added to the introduced floodwaters to bring the phosphate concentration to about $15-20 \mathrm{mg} / \mathrm{L}$. The scaled-up Denison Mine bioleaching operation had overall $U$ recoveries of $69-86 \%$, and produced about $380,000 \mathrm{~kg}$ of $U$ in 1987 . In 1988 , ninety flood-leaching stopes were in various stages of production or preparation.

The Denison Mine has some ore bodies that have been intruded by diabase dikes. Chloritic alteration in the adjacent ore rendered it refractory to conventional mill processing. There are about 4 million tons of such "dike-contaminated ore" at the Denison Mine. Large-scale underground column tests showed the bioleaching method could yield about 70\% U extraction from the chloritic ore. Due to the presence of apatite in this ore, phosphate addition to the mine water is not needed. However, high concentration of Fe (up to $20 \mathrm{~g} / \mathrm{L}$ ) in the interstitial waters and the resultant precipitation of jarosite within the muck pile might be a problem (e.g., plugging of void space, coating of sulfide minerals, entrapment of bacteria) in subsequent leaching cycles.

In numerous laboratory studies, fungal biomass has been demonstrated to have a high capacity for retention of $U$ from aqueous solution (Landa, 2005). Thus, the following field case-study reported by McCready and Gould (1990) is of particular note: in one of the Denison test stopes, where $U$ recovery had progressed to $50 \%$, the $\mathrm{U}$ concentration in the flush solution unexpectedly fell to near zero, despite low $\mathrm{pH}(<2.3)$ and the maintenance of oxidizing conditions. Laboratory tests showed the presence of six species of acid-tolerant fungi and yeasts; two of these fungi showed a high ability to sorb $U$ from solution. This stope had, at one time, been used as an underground garage, and the investigators speculated that spilled petroleum products may have provided a carbon source that promoted the growth of these fungi. An apparent spinoff of this finding was the idea to use immobilized fungal biomass in an engineered, processing column for the continuous recovery of $\mathrm{U}$ from bioleaching, allowing for preconcentration of the dilute (200-500 mg U/L) Denison leachate while still underground, to decrease costs associated with pumping large volumes of solution to the surface (Tsezos et al., 1989). Fungal biomass sorption of $U$ is now a recognized technology, and biomass sources such as spent antibiotic-production materials have been proposed as possible sorbents (Landa, 2005).

Whereas most attention on biological heap leaching has focused on Acidithiobacillus ferrooxidans and Acidithiobacillus thiooxidans, thermophilic iron-oxidizing archaea and bacteria have been used in recent years for the recovery of $\mathrm{Au}, \mathrm{Cu}$ and Mo (Brierley, 2008); future applications to the recovery of $U$ may be possible. Biohydrometallurgy pioneer Henry Ehrlich (2001) has noted that organic acids and ligands such as 2-keto-gluconate generated by some heterotrophic bacteria, and oxalate and citrate generated by fungi may be productive areas for research in the recovery of metals from ores. Indeed, citrate amendment of U-contaminated soils has been shown to increase $U$ uptake by plants (Huang et al., 1998). Bacterially produced siderophores have been shown by Kalinowski et al. (2006) to mobilize U from highly weathered materials, suggesting a possible role in the bioleaching of refractory U ores.

Heap leaching generally involves U ore, but UMT also have been treated in this manner for additional U recovery (e.g., the Solution Engineering, Inc., 1978-1982, "rewashing' or "solution mining” of $\mathrm{U}$ from in-place UMT at Falls City, Texas; http://www.em.doe. gov/bemr/bemrsites/faci.aspx). With sulfuric acid-extraction UMT, ${ }^{226} \mathrm{Ra}$ is likely to occur as a $\mathrm{Ba}(\mathrm{Ra}) \mathrm{SO}_{4}$ coprecipitate, a radium-substituted analog to barite $\left(\mathrm{BaSO}_{4}\right)$. Enhanced dissolution of barite under acidic, pyrite-oxidizing conditions has been hypothesized by Hofmann (1989), which has implications for the mobilization of ${ }^{226} \mathrm{Ra}$ from pyritic, acid-extraction UMT residing in aerobic environments, whether these environs are heap-leach operations or final disposal sites. Although there is evidence of barite dissolution during ore-body oxidation (Hofmann, 1989), the mechanism of thiosulfate-mediated dissolution is in question, owing to the instability of thiosulfate under acidic conditions. The hypothesized importance of thiosulfate during pyrite oxidation was originally derived from column experiments by Granger and Warren (1969), in which oxidation of experimentally high concentrations of residual polysulfide could explain the presence of high $\mathrm{pH}$ values and of high concentrations of thiosulfate during oxidation of mixed iron sulfide phases in the columns. In natural and disturbed, in-place earth materials, thiosulfate concentrations could be low, because thiosulfate is rapidly oxidized to sulfate in the presence of $\mathrm{Fe}(\mathrm{III})$ or pyrite (Nordstrom, 2000). However, because metastable sulfur oxyanion formation is very sensitive to $\mathrm{pH}$, bacterial processes, water-mineral interaction, and other factors, its role in barite dissolution may be dependent on the actual conditions in situ.

\subsection{In situ recovery (ISR) of $U$ using alkaline solutions}

In situ recovery (ISR) of $U$ (also referred to as in situ leach or ISL) accounted for about $18.3 \%$ of worldwide $U$ production in 2002 (IAEA, 2005). Uranium extraction by ISR is the primary method of extraction used in Kazakhstan, the US, and Uzbekistan (IAEA, 2005). It is often used when the deposit is too deep for open pit mining, or if sands are too unconsolidated or have insufficient grade or thickness to be economically extracted using conventional techniques (OCED, 1983). Often, ISR is applied to saturated, confined, sandstone-hosted, roll-front deposits (Fig. 3). Uranium ISR methods involve injection of groundwater that has been fortified 
with an oxidant and a complexing agent through injection wells into the deposit to dissolve $U$ in place. The U-rich groundwater then is pumped to ion exchange resins where the $U$ is extracted, eliminating the need for mining of ore from the ground and processing with conventional milling operations. The ISR process is based on the premise that at mid-pH and low $\mathrm{Eh}, \mathrm{UO}_{2(\mathrm{~s})}$ is stable, whereas under oxidizing conditions, dissolved $\mathrm{U}(\mathrm{VI})$ is soluble as uranyl ions at low $\mathrm{pH}$ and as uranyl-carbonate species at mid-tohigh pH (Mason, 1998).

Although the lixiviant can be either alkaline or acidic, carbonate-based lixiviants are most commonly used in the US (USEPA, 2008b) and especially where there is a high concentration of carbonate minerals, such as calcite, which would cause increased acid consumption (Deutsch et al., 1984). Alkaline lixiviants oxidize $\mathrm{U}(\mathrm{IV})$ to $\mathrm{U}(\mathrm{VI})$ in the rate-limiting step. The alkaline lixiviant also contains carbonate, added as bicarbonate/carbonate or carbon dioxide to form soluble uranyl-carbonate complexes at neutral to slightly alkaline $\mathrm{pH}$ (Mason, 1998):

$\mathrm{UO}_{2(\mathrm{~s})}+1 / 2 \mathrm{O}_{2(\mathrm{aq})}+3 \mathrm{HCO}_{3}^{-}=\mathrm{UO}_{2}\left(\mathrm{CO}_{3}\right)_{3(\mathrm{aq})}^{-4}+\mathrm{H}^{+}+\mathrm{H}_{2} \mathrm{O}$

Subsequently, the resulting aqueous complex is removed from the subsurface with production wells and processed through an ion exchange resin (Mackin et al., 2001):

$2 \mathrm{R}(\mathrm{Cl})+2 \mathrm{Na}^{+}+\mathrm{UO}_{2}\left(\mathrm{CO}_{3}\right)_{2}^{2-}=\mathrm{R}_{2} \mathrm{UO}_{2}\left(\mathrm{CO}_{3}\right)_{2}+2 \mathrm{NaCl}$

or

$$
\begin{aligned}
& 4\left[\mathrm{R}-\mathrm{N}-\left(\mathrm{CH}_{3}\right)_{3} \mathrm{HCO}_{3}\right]+\mathrm{UO}_{2}\left(\mathrm{CO}_{3}\right)_{3}^{4-} \\
& \quad=\left[\left(\mathrm{R}-\mathrm{N}-\left(\mathrm{CH}_{3}\right)_{3}\right)_{4}\right] \mathrm{UO}_{2}\left(\mathrm{CO}_{3}\right)_{3}+4 \mathrm{HCO}_{3}^{-}
\end{aligned}
$$

where $\mathrm{R}$ is the resin ion exchange site. The ion exchange column is eluted with a brine solution to regenerate the exchange sites, concentrating the $U$ in a pregnant solution containing $30 \mathrm{mg} / \mathrm{L} \mathrm{U}$ (OCED, 1983) to $250 \mathrm{mg} / \mathrm{L} \mathrm{U}$ (Pelizza, 2008). Subsequently, the pregnant solution is acidified with $\mathrm{HCl}$ or $\mathrm{H}_{2} \mathrm{SO}_{4}$ to destroy the uranyl carbonate complex, allowing precipitation of uranyl peroxide $\left(\mathrm{UO}_{2} \mathrm{O}_{2}\right)$. The precipitate is then settled, washed, filtered, dewatered and dried at about $400-620^{\circ} \mathrm{C}$ to produce yellowcake (Mackin et al., 2001).

Carbonate may be added to the lixiviant in several different forms. Principal cations that may complex the carbonate or bicarbonate include ammonium $\left(\mathrm{NH}_{4}^{+}\right), \mathrm{K}^{+}$, and $\mathrm{Na}^{+}$, each with different effects on the aquifer. For example, $\mathrm{Na}^{+}$may cause swelling of smectitic clays (IAEA, 2001; Schechter et al., 1985) and decrease permeability of aquifers to a greater extent than $\mathrm{NH}_{4}^{+}$(Grant, 1980). Cost aside, $\mathrm{K}^{+}$is an excellent choice for leaching because it does not cause swelling or clogging due to precipitation (Schechter et al., 1985). Up until about 1980, alkaline lixiviants primarily used ammonium bicarbonate $\left(\mathrm{NH}_{4} \mathrm{HCO}_{3}\right)$ (Grant, 1980). However, if $\mathrm{NH}_{4} \mathrm{HCO}_{3}$ is used as the carbonate source, the $\mathrm{NH}_{4}^{+}$ may be sorbed by clays present in the ore body. An initially rapid (within $2 \mathrm{~h}$ ) sorption of $\mathrm{NH}_{4}^{+}$followed by a slower diffusion-limited exchange by less accessible exchange sites on the clays occurs. The ability of common groundwater cations to prevent $\mathrm{NH}_{4}^{+}$sorption is of the order: $\mathrm{Mg}^{2+}>\mathrm{Ca}^{2+}>\mathrm{K}^{+}>\mathrm{Na}^{+}$, which reflects the affinity of these cations for the clay (Grant, 1980). Following mining, if alkaline groundwater containing $\mathrm{Mg}^{2+}$ and $\mathrm{Ca}^{2+}$ contacts the clays containing sorbed $\mathrm{NH}_{4}^{+}$, elevated concentrations of ammonium in solution become likely, and restoration will be required. In aerobic environments, ammonium, which is toxic to fish and other aquatic life, also may be oxidized to nitrite and nitrate by bacteria; both nitrite and nitrate are regulated as drinking water contaminants by the U.S. Environmental Protection Agency (USEPA) due to their adverse health impacts, especially in infants below the age of 6 months (USEPA, 2009).
Wyoming Basin Uranium roll-front deposit (idealized)

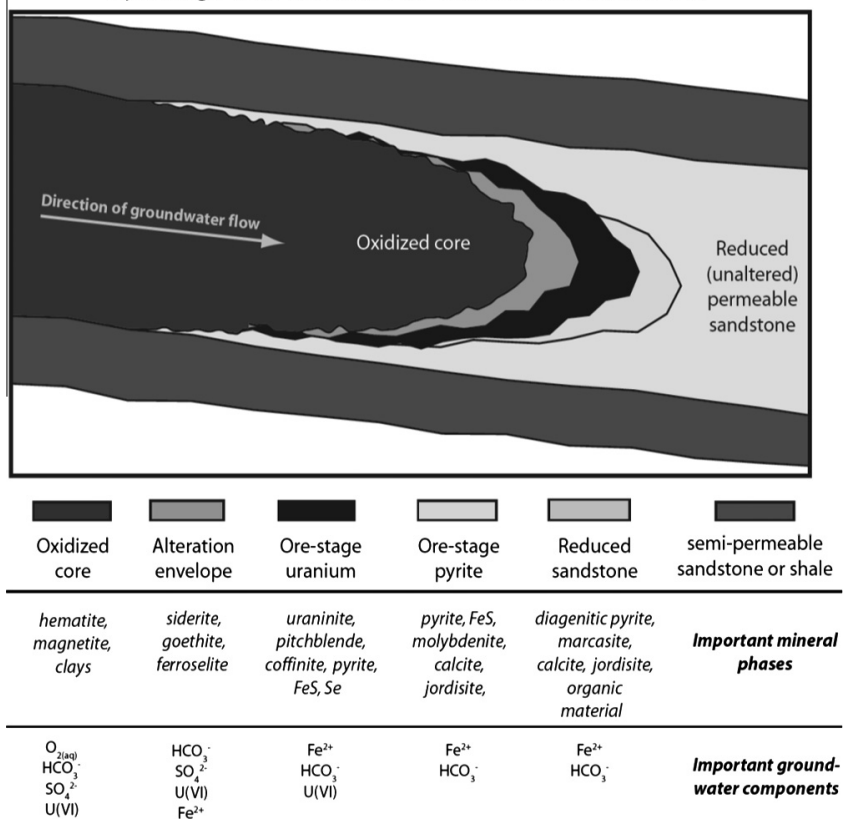

Fig. 3. Schematic of idealized $U$ roll-front deposit showing alteration zones, key minerals, and examples of important groundwater components in each zone. Although thiosulfate $\left(\mathrm{S}_{2} \mathrm{O}_{3}^{2-}\right)$ is often cited as a potentially important groundwater component in ore-stage $U$ and pyrite zones, it may not be present in measurable concentrations in groundwater because of the catalytic oxidation by pyrite and other possible oxidative pathways (Nordstrom, 2000). Figure adapted from (Davis and Curtis, 2007; Granger and Warren, 1969, 1974; Reynolds and Goldhaber, 1983).

Today, the primary source of carbonate in lixiviants is carbon dioxide, sometimes fortified with sodium bicarbonate or sodium carbonate. The use of carbon dioxide without $\mathrm{pH}$ control eliminates the presence of cations, decreasing permeability loss and mitigating issues relating to the use of $\mathrm{NH}_{4}^{+}$(IAEA, 2001). A low-strength bicarbonate solution with a $\mathrm{pH}$ of 6-7 (Shuck, 1979) and bicarbonate concentration of $0.3-1.5 \mathrm{~g} / \mathrm{L}$ achieves typical extraction efficiencies of $60 \%$ (Taylor et al., 2004) to $80 \%$ (Pelizza, 2008). The optimal concentration of inorganic carbon is ore-specific, but is often within the range of 500-5000 mg/L (IAEA, 2001). The concentration of $U$ solubilized has been shown to increase in proportion to the bicarbonate concentration to a point (Liu et al., 2010; Vogt et al., 1982b). However, if sufficient anion is present to complex the $U$, the $U$ recovery rate is unaffected by bicarbonate concentration (Grant et al., 1985) but may increase with increasing residence time (Grant, 1980). High $\mathrm{pH}$ and $\mathrm{Ca}^{2+}$ ultimately may limit $\mathrm{HCO}_{3}^{-}$ concentration in leaching solutions if the solubility limit of calcite is reached (Liu et al., 2010). The leach liquor should remain slightly undersaturated provided that fresh lixiviant is supplied (Liddell and Bautista, 1995). In some cases, indigenous bicarbonate concentrations (on the order of $500 \mathrm{mg} / \mathrm{L} \mathrm{HCO}_{3}^{-}$) may not be affected by the addition of $\mathrm{CO}_{2(\mathrm{~g})}$ during mining, but may increase due to a drop in $\mathrm{pH}$ which causes the dissolution of $\mathrm{CaCO}_{3}$ (M. Pelizza, Uranium Resources, Inc., personal communication, 2011). Geochemical modeling studies have found that greater calcite abundance favors a higher carbonate concentration and promotes the formation of U(VI)-carbonate complexes (Liddell and Bautista, 1995). It should be noted that this modeling study did not include Ca-carbonate-uranyl species, but the presence of dissolved Ca would limit adsorption onto sediments under alkaline conditions (Stewart et al., 2010).

Oxidizing agents can include potassium permanganate, oxygen, and hydrogen peroxide (Mason, 1998). The primary oxidant used in current practice is oxygen gas. Oxidant consumption is affected 
by $U$ ore grade as well as consumption of oxidant by ancillary reduced minerals such as pyrite and carbonaceous material. If the $U$ grade is sufficiently high, dissolution is limited by oxidant mass transfer; $\mathrm{U}(\mathrm{VI})$ concentration in the pregnant lixiviant will increase constantly until uraninite is almost completely dissolved (Liddell and Bautista, 1995). Pyrite may compete for the oxidant to form ferric iron and sulfate. Post-mining solids characterizations have suggested that dissolution of uraninite is faster than pyrite dissolution due to the larger surface area (smaller particle size) of uraninite compared to pyrite crystals; however, some leaching of pyrite is evident (Tsui, 1984).

Oxidation of the deposit with the lixiviant may promote the formation of oxidized solids such as ferric hydroxides that have the potential for sequestering contaminants such as $\mathrm{U}, \mathrm{Ra}, \mathrm{Mn}$ and As. If reducing conditions return after mining, these iron hydroxides may reductively dissolve, providing a new source of contaminants (Anastasi and Williams, 1985). If the initial solid sulfide composition (e.g., as pyrite) exceeds $2-4 \%$, the resulting sulfate concentration may precipitate gypsum $\left(\mathrm{CaSO}_{4} \cdot 2 \mathrm{H}_{2} \mathrm{O}\right)$, which can decrease the permeability of the mining zone. This gypsum also can coprecipitate Ra. Over time, as $\mathrm{pH}$ returns to pre-mining conditions, gypsum may re-dissolve and release Ra back into solution. Other trace metals also may become problematic due to reactions of the lixiviant with associated minerals. For example, $\mathrm{Ca}$ and $\mathrm{Mg}$ released from dissolving clays may combine with injected carbonate to precipitate calcium and magnesium carbonates (IAEA, 2001). A recent study on an ISR operation in China suggested that the malfunction of an alkaline ISR mine resulted from calcite precipitation (Sun et al., 2010), which caused aquifer plugging and decreased permeability. Precipitation of calcite also could provide a sink for uranyl at high pH during mining operations, decreasing extraction efficiency. Spectroscopic evidence also suggests that uranyl ion substitutes for one Ca and two carbonate ions in the calcite structure to provide a stable lattice position in natural calcite (Kelly et al., 2003); additional information on U substitution into calcite can be found in Landa (2004). As the equilibrium pre-mining $\mathrm{pH}$ returns, calcite may dissolve providing a source of dissolved $U$. However, there are some preventative practices that may mitigate these effects. Reverse osmosis (Osiensky et al., 1988), water softening, and ion exchange (Shuck, 1979) may be employed to avoid aquifer plugging. The use of Ca-precipitation inhibiting agents such as sodium metaphosphate $\left(\mathrm{Na}_{3} \mathrm{PO}_{4}\right)$ and pyrophosphate $\left(\mathrm{Na}_{2} \mathrm{P}_{2} \mathrm{O}_{7}\right)$ at concentrations of $5-10 \mathrm{mg} / \mathrm{L}$ can inhibit calcite precipitation (IAEA, 2001). However, the addition of phosphate also influences the saturation of uranium-phosphate minerals such as autunite $\left[\mathrm{Ca}\left(\mathrm{UO}_{2}\right)_{2}\left(\mathrm{PO}_{4}\right)_{2} \cdot(10-12) \mathrm{H}_{2} \mathrm{O}\right]$ and the adsorption of uranyl onto solids such as goethite (Singh et al., 2010), which could inhibit the recovery of $\mathrm{U}$, depending on $\mathrm{pH}$, redox conditions, and the concentrations of other major elements such as $\mathrm{Ca}$ and $\mathrm{Mg}$. Pre-flushing the ore zone with $\mathrm{KCl}$ also could prevent $\mathrm{CaCO}_{3}$ precipitation and provides a tracer to define the subsurface hydrology (Schechter et al., 1985). In any case, because each of these methods is based on the local geochemistry of the deposit and lixiviant chemistry, selection of a method for aquifer plugging mitigation should be conducted on a site-specific basis to achieve optimum efficacy. More research would be also helpful in understanding controlling geochemical processes at U ISR sites and the impacts on both $U$ recovery and post-mining environmental remediation.

In addition to $U$ and its decay products, other groundwater constituents associated with $U$ deposits also are often mobilized. Table 2 shows maximum concentrations of constituents in the pregnant lixiviant reported in various ISR licensing documents (Mackin et al., 2001). Some of these elevated concentrations may be caused by a complex series of dissolution, precipitation, sorption, and desorption reactions that take place as the oxygen and inorganic carbon react with the $U$ ore and associated minerals.
Table 2

Highest pregnant lixiviant contaminant concentrations compiled from ISR licensing documents (Mackin et al., 2001).

\begin{tabular}{ll}
\hline Element or Measurement & Concentration $(\mathrm{mg} / \mathrm{L})$ \\
\hline Arsenic & 0.3 \\
Boron & 0.2 \\
Chloride & 1800 \\
Copper & 0.04 \\
Iron & 0.02 \\
Manganese & 6 \\
Molybdenum & 62 \\
Nickel & 0.09 \\
Selenium & 5 \\
Sulfate & 1200 \\
Radium-226 & $126 \mathrm{~Bq} / \mathrm{L}(3,400 \mathrm{pCi} / \mathrm{L})$ \\
Radon-222 & $29,630 \mathrm{~Bq} / \mathrm{L}(800,000 \mathrm{pCi} / \mathrm{L})$ \\
Barium & 0.6 \\
Cadmium & 0.01 \\
Chromium & 0.03 \\
Fluoride & 1 \\
Lead & 0.01 \\
Mercury & $<0.0001$ \\
Nickel & 0.09 \\
Nitrate & 1 \\
Silver & $<0.01$ \\
Total dissolved solids & 5500 \\
Uranium $\left({ }^{234} \mathrm{U}+{ }^{235} \mathrm{U}+{ }^{238} \mathrm{U}\right)$ & $250 \mathrm{mg} / \mathrm{L}$ or $6,296 \mathrm{~Bq} / \mathrm{L}(170,000 \mathrm{pCi} / \mathrm{L})$ \\
\hline
\end{tabular}

Fig. 3 describes some of the minerals that may be present in rollfront deposits. Uranium mineralization in roll-front deposits usually consists predominantly of uraninite and coffinite (OCED, 1983), possibly with minor amounts of tyuyamunite $\left[\mathrm{Ca}\left(\mathrm{UO}_{2}\right)_{2}\right.$ $\left(\mathrm{VO}_{4}\right)_{2} \cdot \mathrm{H}_{2} \mathrm{O}$ ] (Mackin et al., 2001). Uranium ore is located at the redox interface between the oxidized sediment (hematite, limonitic material, ferroselite and native selenium) and unaltered reduced sediment [organic carbonaceous material, pyrite or marcasite (e.g., Deutsch et al., 1985; Granger and Warren, 1969; Reynolds and Goldhaber, 1983), often associated with sulfide (Goldhaber et al., 1978) and methane (OCED, 1983)]. In addition, Mo, As and V often are abundant locally in the sediments associated with roll-front deposits. Uranium deposited as a late generational stage (e.g., as amorphous grain coatings) is more amenable to ISR than early stage deposition (Stewart et al., 2000). Uranium also may occur as matrix or grain fracture fillings or as part of the clay on the host sandstone. Although mineralogical studies in the ISR mining industry have been limited and/or infrequently documented (Stewart et al., 2000), it is important to determine the solubility of $U$ minerals as well as to identify ancillary minerals that may release trace elements capable of interfering with the ISR process and contaminating groundwater. For example, tyuyamunite is relatively insoluble in carbonate-based ISR solutions and pyrite may consume the oxidant (Stewart et al., 2000; Tsui, 1984). Extraction of U via ISR mining also can be inhibited when $U$ minerals are not accessible to the lixiviant, such as when $U$ is coated with clays, or when U occurs as inclusions within host grains (Stewart et al., 2000). In some cases, carbonaceous material also can surround $U$ minerals and reduce leaching efficiency (Vogt et al., 1982a, $1982 b$ ). A study of U mineralization of sandstone-hosted U samples from Nebraska and Wyoming suggested that if $U$ mineralization forms a cement (e.g. a U phosphate) rather than a loose matrix between sand grains, the lixiviant may generate a preferential flow path around the U ore (Stewart et al., 2000), rendering the ISR process ineffective. From an economic perspective, the "effective in situ ore grade" may be defined as the proportion of ore that can be contacted and solubilized by the selected leaching fluid. Thus, for carbonate lixiviants, the effective in situ ore grade for horizons containing significant refractory minerals would be substantially less than the total $U$ assay might indicate (Tsui, 1984). 
In addition to hydrologic considerations, the chemical reactions controlling the dissolution of $U$ and other trace metals involve a complex series of interactions among $U$, gangue minerals, $\mathrm{pH}$, and concentrations of carbonate, calcite, and Ca under differing redox conditions. Interactions should be carefully examined on a site-specific basis in light of differing physical aquifer parameters such as porosity, hydraulic conductivity, pressures and flow rates to fully understand implications for both $U$ production and groundwater restoration. Because ISR of $U$ is essentially "underground hydrometallurgy" and requires manipulation of the U geochemistry in the subsurface aquifer, it offers a new set of challenges with respect to groundwater restoration. Issues related to groundwater quality from both ISR and conventional $\mathrm{U}$ mining will be discussed in greater detail in following sections.

\section{Remediation, site closure and aquifer restoration}

\subsection{Groundwater contamination from conventional mining and ISR}

The U mining and milling activities following World War II to supply nuclear weapons and later to provide fuel for the emerging civilian nuclear power industries from the late 1960s (Mudd and Diesendorf, 2008) occurred prior to the promulgation of most environmental laws and regulations. It was not until 1972 that the Federal Clean Water Act in the US was passed; thereafter many states enacted water quality laws and regulations that addressed, in part, discharges from U mines and mills. In 2000, USEPA revised federal radionuclide regulations for drinking water that had been in effect since 1977. The current maximum contaminant levels (MCL) include a combined ${ }^{228+226} \mathrm{Ra}$, concentrations of $5 \mathrm{pCi} / \mathrm{L}(0.185 \mathrm{~Bq} / \mathrm{L})$, and a $U$ concentration of $0.03 \mathrm{mg} / \mathrm{L}$ (USEPA, 2000; http://water. epa.gov/lawsregs/rulesregs/sdwa/radionuclides/regulation.cfm). The U MCL is based on metal toxicity rather than radiological considerations. In the wake of curtailed conventional $U$ mining in the United States in the 1980s due to a drop in price and demand, and the passage by Congress in 1978 of the Uranium Mill Tailings Radiation Control Act (UMTRCA), much of the research related to U mining largely shifted to the reclamation of "legacy" contamination.

Legacy U groundwater contamination can be either directly or indirectly related to $U$ mining and milling activities. For example, groundwater in some areas such as the Grants Mineral Belt within the San Juan Basin in New Mexico, which produced in excess of 154,221 metric tons of $\mathrm{U}_{3} \mathrm{O}_{8}$ between 1948 and 2002 (McLemore, 2007; Schoeppner, 2008), has been affected by the release of wastes from U mining. Releases of $\mathrm{U}, \mathrm{Mo}, \mathrm{Se},{ }^{228+226} \mathrm{Ra}$, sulfate, and other constituents to groundwater resulting in increases in total dissolved solids (TDS) have occurred because of the presence of pit lakes, evaporation ponds, mill tailings pond seepage, and mine dewatering. Prior to the 1980s, water generated during mine dewatering activities was discharged to the surface and allowed to flow into natural watercourses without any treatment, providing a direct source of contamination of sediments, alluvial aquifers, and deeper aquifers in areas of faulting (Schoeppner, 2008). From 1967 to 1986, dewatering of the Church Rock U mine in New Mexico released a total of $560 \times 10^{6} \mathrm{~g}$ of $\mathrm{U}$ into the Puerco River, estimated from historical water quality and discharge data (Van Metre and Gray, 1992). In some cases, releases were accidental. The failure of the Church Rock UMT dam in 1979 resulted in the release of approximately $1.5 \times 10^{6} \mathrm{~g}$ of $\mathrm{U}$ and $1.7 \times 10^{12} \mathrm{~Bq}(46 \mathrm{Ci})$ into the Puerco River (Van Metre and Gray, 1992). Most of the gross alpha activity in the dewatering effluent was derived from the decay of $U$, whereas alpha emitters other than U left behind after the milling process were responsible for the alpha activity in the tailings (Van Metre and Gray, 1992). Mass-balance calculations on alluvial groundwater suggested that most of the $U$ was sorbed onto sediments or taken up by plants (Van Metre and Gray, 1992). However, a recent evaluation of the Puerco River sediments collected downstream from the Church Rock tailings did not reflect the persistence of U-bearing phases in the sediments. DeLemos et al. (2008) found that the particles from the Church Rock tailings contain highly soluble uranyl silicate or phosphate phases, and have suggested that such phases would have dissolved in pore waters and not have persisted in the upper sediments; rather, they would have been mobilized downward into the alluvial aquifer or been carried downstream during flood events as aqueous uranyl species.

In some cases, direct evidence of seepage from mill tailings is evident. For example, a U mill in the San Mateo Basin within the Grants Mineral Belt in northwest New Mexico began operations in 1958 and continued through 1990 using alkaline leaching of the ore, followed by ammonia precipitation of yellowcake. During operation, seepage water from the estimated 22 million metric tons of mill tailings (USEPA, 2006) was found to contain $0.92 \mathrm{mg} / \mathrm{L}$ of $\mathrm{Se}$, and $1070 \mathrm{~Bq} / \mathrm{L}$ and $1.9 \mathrm{~Bq} / \mathrm{L}$ of gross alpha activity and ${ }^{226} \mathrm{Ra}$, respectively (USEPA, 1975). Additionally, seepage has contaminated underlying aquifers with $\mathrm{U}^{230} \mathrm{Th}, \mathrm{Cr}, \mathrm{Mo}, \mathrm{V}, \mathrm{SO}_{4}^{2-}, \mathrm{Cl}^{-}$, $\mathrm{NO}_{3}^{-}$and TDS (USEPA, 2006). Some trace metals have since migrated down into the alluvial aquifer as well as the Upper, Middle and Lower Chinle aquifers at the site. The San Mateo alluvial aquifer is of primary concern because it is the most contaminated and had previously provided a source of potable water to nearby residents (USEPA, 2006). Restoration of the groundwater aquifer at the tailings site began in 1977 and is scheduled to be completed in 2015. The restoration program was designed to remove the contaminants from the groundwater by collecting contaminated water and flushing the alluvial aquifer and Upper Chinle aquifer with deep-well supplied fresh water or water produced from a reverse osmosis plant to reverse the natural flow of groundwater away from residences (USEPA, 2006). Although the remediation efforts and aquifer recharge appear to be effective at preventing further migration and lowering concentrations of contaminants (USEPA, 2006), a few residential wells still had concentrations of $U$ and Se that exceeded drinking water standards over 30 years after groundwater remediation began (ASTDR, 2009).

Although many instances of elevated concentrations of contaminants in groundwater have been attributed to poor practices prior to the establishment of a regulatory framework, there are examples of concerted efforts to adhere to strict environmental regulations that have shown success in meeting groundwater quality standards. The Ranger Uranium project in Australia has successfully designed a strict control over water treatment and releases to meet increased environmental regulation under the Australian and New Zealand Environment and Conservation Council-Agricultural and Resources Management Council of Australia and New Zealand (ANZECC and ARMCANZ) guidelines introduced in 2000 (ANZECC and ARMCANZ, 2000; Ferguson and Mudd, 2011). The regulatory regime invokes a three-tier system for water quality based on natural variability and/or ecotoxicology in an effort to provide a higher degree of biodiversity protection. For example, a $0.006 \mathrm{mg} / \mathrm{L}$ surface water standard for U was established for downstream at the Alligator Rivers Region (both a World Heritage and Ramsar Convention on Wetlands site) based on chronic ecotoxiological data and testing of five indicator species for the aquatic ecosystem estimated to protect $99 \%$ of aquatic biodiversity. These indicator species are from five local species of different ecosystem trophic levels: Chlorella sp. (green algae), Lemna aequinoctialis (duckweed), Moinodaphnia macleayi (water flea), Hydra viridissima (green hydra) and Mogurnda mogurnda (purple-spotted gudgeon fish) (Ferguson and Mudd, 2011). Although there are still some concerns over the dispersion of U-containing sediments during peak loads, to date, the Ranger project has met regulatory requirement 
for $U$ in terms of protecting groundwater quality. As noted by the IAEA, however, these successes continue to be overshadowed by past performances: "Despite the acceptable performance of new mines, legacy issues arising from past inappropriate or non-existent environmental standards still adversely impact the perception of the current uranium mining and processing industry" (IAEA, 2009a).

Methods used in ISR differ significantly from conventional underground and open pit U mining with a smaller land-surface disturbance area, the generation of no overburden, mine waste rock, or tailings. Solid wastes generated aboveground from ISR operations include materials from the drilling of wells, contaminated equipment, spent resin, and waste-pond sediments (Pelizza, 2008). These solid wastes often contain carbonate and sulfate minerals and can have several hundred $\mathrm{mg} / \mathrm{kg} U$ and 11.1$111 \mathrm{~Bq} / \mathrm{g}{ }^{26} \mathrm{Ra}\left(300-3000 \mathrm{pCi} / \mathrm{g}{ }^{226} \mathrm{Ra}\right.$ ) (USEPA, 2008a). The predominant waste products in ISR are residual elevated trace metal(loid)s remaining in the mining zone, liquid effluents from the well field, and process circuit and reject water from aquifer restoration processes (Pelizza, 2008). Data are limited on wastewater pond composition but are thought to contain $U$ and ${ }^{226} \mathrm{Ra}$ concentrations ranging from background levels to $111 \mathrm{~Bq} / \mathrm{L}$ (3000 pCi/L) (USEPA, 2008a). Characterization of post-leach ore samples from the Grants Mineral Belt suggested that gangue minerals containing Se and Mo were relatively unreactive to a mild carbonate lixiviant (Tsui, 1984), and that the alkaline leaching process does not mobilize (mainly cationic) daughter products (Paul et al., 1982). However, others have suggested that potential groundwater effects imposed by the ISR mining process may include: (1) mobilization of oxyanions including Se, As, V, and Mo, (2) mobilization of residual dissolved $U$, (3) mobilization of U-series decay daughter products including ${ }^{226} \mathrm{Ra}$ and ${ }^{222} \mathrm{Rn},(4)$ increased salinity, and (5) release of organic pollutants originating from leach fluid interactions with organic constituents indigenous to the ore (Krumhansl et al., 2009). Potential groundwater effects are illustrated in Table 3, showing post-mining (pre-restoration) water quality. Loss of fluids from the mining zone (excursions) which contain elevated concentrations of constituents of concern may be indicated by the detection of $\mathrm{SO}_{4}^{2-}, \mathrm{Cl}^{-}$and TDS in monitoring wells which also become elevated during ISR (Deutsch et al., 1985). These examples highlight the importance of establishing an understanding of the geochemical controls of these constituents related to ISR in an effort to develop more robust methods for groundwater restoration.

\subsection{Coupled processes affecting other elements of concern}

Uranium is seldom the only element that poses environmental concern in mining, milling, and disposal operations. Common elements that co-occur with $U$ in many types of ores include As, Se, $\mathrm{Mo}, \mathrm{Ni}, \mathrm{Zn}, \mathrm{V}, \mathrm{Fe}, \mathrm{S}, \mathrm{Al}$, and $\mathrm{Mg}$. In addition, other radionuclides in the ${ }^{238} \mathrm{U}$ decay series (e.g., ${ }^{230} \mathrm{Th},{ }^{226} \mathrm{Ra}$, and ${ }^{210} \mathrm{~Pb}$ ) are commonly found. In evaluating disposal and remediation options for mineand milling-impacted sites, the biogeochemistry of these other elements should also be considered. In some cases, an effective solution for $U$ contamination may cause mobilization of other elements into surface water or groundwater.

Of the ${ }^{238} \mathrm{U}$ daughter products, ${ }^{226} \mathrm{Ra}$ is the radionuclide of major concern in assessing the environmental impact of UMT. Coprecipitation with, or sorption on, Fe/Mn hydrous oxides are modes of retention of ${ }^{226} \mathrm{Ra}$ in the UMT solids, neutralized acid-mill effluent, and reactive barriers (Landa and Gray, 1995). Coprecipitation with barite $\left(\mathrm{BaSO}_{4}\right)$ represents another important mode of ${ }^{226} \mathrm{Ra}$ retention in UMT (Landa, 2004). Conventional U mill effluents are typically dosed with $\mathrm{BaCl}_{2}$ and the $\mathrm{Ba}(\mathrm{Ra}) \mathrm{SO}_{4}$ allowed to settle-out prior to environmental discharge. At the Königstein U-mine in Germany, sulfuric

Table 3

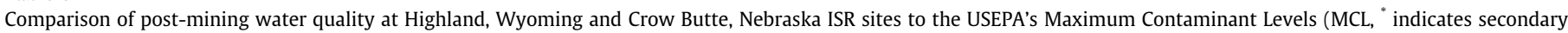
MCL) (USEPA, 2009; Davis and Curtis, 2007). All values in mg/L, except pH and radium (pCi/L, Bq/L).

\begin{tabular}{|c|c|c|c|}
\hline Parameter & Highland, Wyoming & Crow Butte, Nebraska & MCL or "Secondary MCL \\
\hline Alkalinity & 591 & 875 & - \\
\hline Aluminum ${ }^{*}$ & 0.1 & & 0.05 to 2 \\
\hline Ammonium & 0.7 & 0.277 & - \\
\hline Arsenic & 0.001 & 0.021 & 0.01 \\
\hline Barium & 0.1 & $<0.10$ & 2 \\
\hline Bicarbonate & - & 1068 & - \\
\hline Boron & 0.1 & 1.22 & - \\
\hline Cadmium & 0.03 & $<0.01$ & 0.005 \\
\hline Calcium & 313.4 & 88.7 & - \\
\hline Chloride $^{*}$ & 212.6 & 583 & 250 \\
\hline Chromium & 0.05 & $<0.05$ & 0.1 \\
\hline Copper ${ }^{*}$ & 0.02 & 0.035 & 1 \\
\hline Fluoride $^{*}$ & 0.2 & 0.41 & 2 \\
\hline Iron $^{*}$ & 0.05 & 0.078 & 0.3 \\
\hline Lead & 0.05 & $<0.05$ & 0.015 \\
\hline Magnesium & 59.5 & 23 & - \\
\hline Manganese & 0.66 & 0.075 & 0.05 \\
\hline Mercury & 0.001 & $<0.001$ & 0.002 \\
\hline Molybdenum & 0.1 & 0.487 & - \\
\hline Nickel & 0.08 & 0.068 & - \\
\hline Nitrate & 0.2 & 1.01 & 10 \\
\hline Nitrite & 0.1 & $\mathrm{~N} / \mathrm{A}$ & 1 \\
\hline $\mathrm{Ph}^{*}$ & 6.78 & 7.35 & $6.5-8.5$ \\
\hline Potassium & 13.4 & 30 & - \\
\hline Radium-226 & $121 \mathrm{~Bq} / \mathrm{L}(3300 \mathrm{pCi} / \mathrm{L})$ & $29 \mathrm{~Bq} / \mathrm{L}(786 \mathrm{pCi} / \mathrm{L})$ & $0.19 \mathrm{~Bq} / \mathrm{L}(5 \mathrm{pCi} / \mathrm{L})$ \\
\hline Selenium & 0.99 & 0.124 & 0.05 \\
\hline Sodium & 80.8 & 1100 & - \\
\hline Sulfate ${ }^{*}$ & 380.6 & 1100 & 250 \\
\hline Total dissolved solids ${ }^{*}$ & 1507 & 3700 & 500 \\
\hline Total carbonate & 720 & - & - \\
\hline Uranium & 40.19 & 12.2 & 0.030 \\
\hline Vanadium & 0.19 & 0.96 & - \\
\hline Zinc $^{*}$ & 0.04 & 0.038 & 5 \\
\hline
\end{tabular}




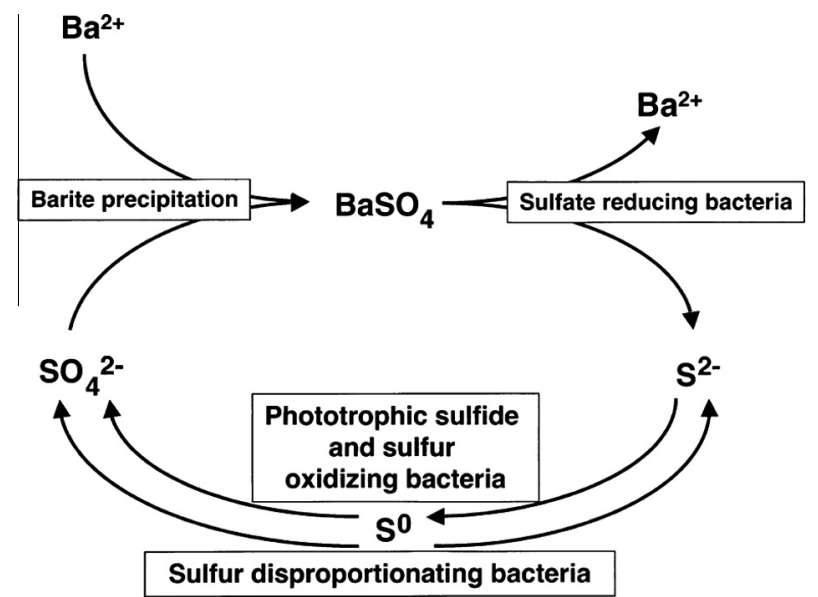

Fig. 4. Bacterially-mediated sulfur cycling reactions that may influence the solubility of barite (Senko et al., 2004). Reprinted with permission from Elsevier, Ltd., copyright 2004.

acid was used as a leaching agent, leaving high concentrations of metals such as $\mathrm{Zn}$ and $\mathrm{U}$ in the pore water during the decommissioning phase. A variant on this aboveground practice of $\mathrm{BaSO}_{4}$ precipitation-namely, formation of a $\mathrm{BaSO}_{4}$ grout in the pore space-has been used to immobilize these metals (Jenk et al., 2006; Ziegenbalg, 2006). The method would presumably also have utility in groundwater systems where dissolved ${ }^{226} \mathrm{Ra}$ is present.

Because sulfuric acid is the most commonly used extracting agent at conventional U-mills, an understanding of geochemical processes influencing sulfate phases is key in assessing contaminant mobility in the disposal environment. Microbially mediated reductive dissolution of sulfate phases in UMT is recognized as a possible release mechanism for ${ }^{226} \mathrm{Ra}$ from UMT residing in anaerobic environments (Landa et al., 1986; Martin et al., 2003). Sulfate reducing bacteria can grow with gypsum (Karnachuk et al., 2002), anglesite $\left(\mathrm{PbSO}_{4}\right)$ (Karnachuk et al., 2002; Schröder-Wolthoorn et al., 2008), or barite (Fedorak et al., 1986; Karnachuk et al., 2002) as electron-accepting substrates, thereby leading to the dissolution of these minerals and the soluble release of bulk or trace constituents that are not readily precipitated as insoluble sulfides. Thus ${ }^{226}$ Ra coprecipitated with barite in UMT and later residence in sulfate-reducing environments is subject to release into contacting waters, while ${ }^{210} \mathrm{~Pb}$ present as anglesite would likely precipitate with secondary galena ( $\mathrm{PbS})$.

Anaerobic environments where such dissolution may occur include UMT under soil and vegetative covers (see (Papanicolaou et al., 2010) for an analogous case with a phosphogypsum dump). Solubilized Ra may later be precipitated in barite or other solid sulfate phases such as jarosite $\left[\mathrm{KFe}_{3}\left(\mathrm{SO}_{4}\right)_{2}(\mathrm{OH})_{6}\right]$; both minerals are commonly found in oxic acid-mine drainage systems (e.g., (Jambor et al., 2000; Romano et al., 2010)). Indeed the bacterially-mediated sulfur cycling reactions described by Senko et al. (2004, Fig. 4) as modulating the solubility of barite in a springfed stream system provide a good analog for the type of biological controls on Ra solubility that can be seen in surface and subsurface environments containing UMT, pyrite-bearing U-ore spoil piles, and a variety of technologically enhanced naturally occurring radioactive materials [TENORM; see (Landa, 2007)]. In particular, the association of barite deposition with microbial mats noted in this study provides useful tips for the selection of environmental monitoring sites in areas of potential Ra contamination.

Mixed crystals are possible in sulfate minerals in UMT. For example, laboratory studies by Landa et al. (1994) showed that ${ }^{210} \mathrm{~Pb}$-rich anglesite $\left(\mathrm{PbSO}_{4}\right)$ could occur as inclusions in gypsum laths that formed in acid milling solutions. This ${ }^{210} \mathrm{~Pb}$ would likely be immobile in sulfate-reducing environments, as noted above. However Papanicolaou et al. (2010) have noted the possible facilitated transport of colloid sized metal(II) sulfide particles as a possible mobilization mechanism for these elements.

Under conditions simulating an acid-leach U-mill effluent environment, trace amounts of Th could coprecipitate with barite, celestite $\left(\mathrm{SrSO}_{4}\right)$, anglesite and jarosite, but was limited in the case of gypsum (Landa et al., 1995). If reductive dissolution of such bulk phases occurred in a disposal or subsequent depositional environment, the lower solubility of ThS as compared to $\mathrm{ThSO}_{4}$, as well as precipitation of hydrolysis products such as $\mathrm{Th}(\mathrm{OH})_{4}$ and $\mathrm{ThO}_{2}$, and the sorption of cationic Th species by clay minerals, would likely limit the mobility of ${ }^{230} \mathrm{Th}$, the long-lived parent of ${ }^{226} \mathrm{Ra}$.

At the former Wismut operation site "Freital" near Dresden, Germany, hydrochloric acid, rather than sulfuric acid, was the extractant in the acid leaching of $U$ ores during the period 19491960 (Scheinost et al., 2006). The reason for this reagent selection is unclear - perhaps it relates to the coal associated with pitchblende in the local ore, or availability of alternative acids in postwar East Germany. An unintended consequence of this selection was the increased concentration of Ra in mill effluents and of water-soluble $\mathrm{Ra}$ in the tailings solids, as $\mathrm{RaCl}_{2}$ is far more soluble than $\mathrm{RaSO}_{4}$. Parallels to this are seen in the case of naturally-occurring radioactive materials (NORM) from non-nuclear industries: at a plant in Oregon where zircon-bearing sands were treated by chlorination for the recovery of zirconium $(\mathrm{Zr})$, niobium $(\mathrm{Nb})$, tantalum (Ta), and hafnium (Hf), the seepage water at the tailings disposal site had ${ }^{226} \mathrm{Ra}$ concentrations up to $1.7 \mathrm{kBq} / \mathrm{L}(45,000 \mathrm{pCi} / \mathrm{L})$ (Landa, 2007). At the Freital site, sulfate associated with pyrite oxidation in the tailings, leachate from the overlying construction debris (presumably containing gypsum in the form of drywall and plaster of Paris) and some usage of sulfuric acid from ore extraction at the site may actually limit Ra mobility (A. Scheinost, written communication, 2010).

Arsenic is another element of particular concern due to its toxicity, and can be present in substantial quantities in a variety of $U$ ores, including those mined in the Ore Mountains ("Erzgebirge") of eastern Germany (Schneider et al., 2001) and the Athabasca Basin in northern Saskatchewan (Pichler et al., 2001; Mahoney et al., 2007); the latter deposits contain up to $10 \%$ As. Because As is not recovered as an economic product during $U$ milling, high concentrations can be present in overburden, waste rock, and tailings. The fate of As in several tailings management facilities in Saskatchewan, Canada (e.g., Rabbit Lake, McClean Lake) has been studied extensively to determine the mobility of As from treated $U$ tailings. Arsenic can be mobilized by acidic mine waters and by $U$ mill extractants; spent sulfuric-acid $(\mathrm{pH} \leqslant 1.5)$ leaching solutions (raffinates) at the McLean Lake operations had As concentrations of up to $6800 \mathrm{mg} / \mathrm{L}$ (Mahoney et al., 2007). Additions of both ferric sulfate and lime are used at acid leach mills in Saskatchewan to reduce the concentrations of As in acidic raffinates (Mahoney et al., 2005), resulting in the precipitation of poorly crystalline ferric arsenate [scorodite, $\left(\mathrm{FeAsO}_{4} \cdot 2 \mathrm{H}_{2} \mathrm{O}\right)$ ] and ferrihydrite. Because the Saskatchewan ores also are enriched in $\mathrm{Ni}$ (up to $5 \%$ ), other As-bearing phases such as annabergite $\left[\mathrm{Ni}_{3}\left(\mathrm{AsO}_{4}\right)_{2} \cdot 8 \mathrm{H}_{2} \mathrm{O}\right]$ may play a role in controlling As solubility in disposed tailings (Mahoney et al., 2007).

At the Rabbit Lake mill in Saskatchewan, slaked lime $\left[\mathrm{Ca}(\mathrm{OH})_{2}\right]$ is added rapidly to the effluent to continuously raise the $\mathrm{pH}$ from about 1 to 11 (Pichler et al., 2001). Poorly crystalline scorodite is unstable at $\mathrm{pH}>3.1$, and thus does not persist. Ferrihydrite sorption of the released As (Moldovan and Hendry, 2005) and/or crystalline scorodite (Langmuir et al., 2006) controls As concentrations in the pore waters of neutralized tailings.

The addition of lime to the $\mathrm{H}_{2} \mathrm{SO}_{4}$-based raffinate leads to the precipitation of large quantities of gypsum. One might expect the 
gypsum to be an important sink for $\mathrm{As}(\mathrm{V})$, the dominant As species, but this does not appear to be the case; As tends to adsorb onto ferrihydrite or precipitate as a ferric arsenate phase (Langmuir et al., 1999; Pichler et al., 2001). The in situ aging to more crystalline ferric oxyhydroxide phases such as goethite would tend to decrease the retention of As, but the presence of specifically adsorbed As, sulfate, and silicate is hypothesized to stabilize the ferrihyrite for many years in this case (Langmuir et al., 1999).

Disposal of neutralized slurry in the tailings pond at McLean Lake from 1999 to 2004 has resulted in a $32 \mathrm{~m}$ thick deposit. Pore water ( $\mathrm{pH} 7.8$ ) in this sediment was sampled by Langmuir et al. (2006) and showed an average As concentration of $4.1 \mathrm{mg} / \mathrm{L}$; the concentration decreased to $1-2 \mathrm{mg} / \mathrm{L}$ in the oldest tailings. The tailings facilities are maintained under oxic conditions, and diffusion out of the pit is slow and limits transport of As from the site (Moldovan et al., 2008).

The success of the strategy used at McLean Lake depends on persistent oxidizing conditions, as reductive dissolution of $\mathrm{Fe}(\mathrm{III})$ minerals could release As and other metal(loids) into the groundwater. An example of this effect was observed in a contaminated watershed adjacent to an abandoned U mine in South Dakota, where As and $\mathrm{U}$ were associated with $\mathrm{Fe}$ - and Mn-oxides and carbonate phases in wetland sediments. Uranium was sequestered from water moving through the wetland, while As(III) and Fe(II) were mobilized from reductive dissolution of $\mathrm{Fe}$ (III) phases (Kipp et al., 2009). The opposing mobilization behavior of As and U under reducing conditions can be an important consideration in longterm simultaneous sequestration of these elements. However, this effect can be mitigated when sulfate reduction results in Fe- and As-sulfide precipitates, as demonstrated at a former UMT site in Durango, Colorado. Zero-valent iron permeable reactive barriers removed $\mathrm{U}, \mathrm{As}, \mathrm{V}, \mathrm{Zn}, \mathrm{Mo}$, and Se from groundwater under strongly reducing conditions due to the precipitation of sulfide minerals (Morrison et al., 2002).

\subsection{Reducing environment disposal}

Oxidized, pyritic, subaqueous UMT represent an important subclass. In these UMT, a period of surface disposal is followed by flooding and underwater storage. During the initial, aerial period, oxidation of pyrite in the tailings leads to high $\mathrm{Fe}(\mathrm{II})$ concentrations in the porewaters and low $\mathrm{pH}$. At the air/tailings interface during aerial exposure, and at the aerated water/tailings interface upon flooding, a layer of hydrous ferric oxide forms. This upper few centimeters of tailings can be highly dynamic, with the retention or release of radionuclides and metals to the water column responding to the influences of environmental factors such as photosynthetic activity, turbulence-driven resuspension, and accumulation of organic sediments. Peacey et al. (2002) have studied the flux of bulk constituents, trace elements, and radionuclides from the Quirke UMT near Elliot Lake, Ontario during the period 1956-1990.

The decommissioning of the Quirke mine (near Elliot Lake, Ontario) disposal site involved dividing the 192-ha impoundment (containing 45 million metric tons of UMT) into five diked cells. In 1992, the dewatered tailings were tilled with agricultural lime and flooded to a water depth that varies seasonally from a minimum depth $0.6 \mathrm{~m}$ to a maximum of $3 \mathrm{~m}$. This water cover is designed to limit radon ( $\mathrm{Rn}$ ) flux out of the tailings and oxygen flux into the tailings. The tailings are approximately $30 \mathrm{~m}$ thick. The underlying light-gray tailings contain about $1-8 \%$ pyrite. The upper layer $(0-4 \mathrm{~cm})$ of oxidized, red-brown tailings contains $1 \%$ or less of pyrite. Field results indicate that oxygen is depleted below a depth of about $3 \mathrm{~cm}$. Microbially driven, reductive dissolution of Ra-bearing phases such as Fe- and Mn-oxyhydroxide and barite is likely in such previously oxidizing environments, and may account for the increasing ${ }^{226} \mathrm{Ra}$ seen in the overlying water between 1993 and 1999. The growth of aquatic vegetation, and waste management practices such as the disposal in Cell 14 of 30,000 metric tons of municipal sewage sludge have the potential to create reducing environments in depositional environments occupied by UMT (Peacey et al., 2002; Landa, 2003).

\subsection{Seepage to ephemeral streams}

The Mary Kathleen acid-leach UMT were produced during operations from 1956 to 1982 treating pyritic ore (average 2\% S) in a semi-arid region of northwestern Queensland, Australia, and disposed of without liming in an unlined impoundment. Decommissioning involved capping with soil and waste rock. However seepage from the base of the tailings dam retaining wall has been continuous since the site closure, resulting in ponded water with an abundance of Fe-rich gelatinous precipitates ("yellow-boy") and a peripheral wetted zone with white, sulfate-rich efflorescent salts. Examination of an ephemeral creek draining this pond area during the dry season in 1999 and 2003 showed an abundance of efflorescent salts on the stream bank and bed for about one $\mathrm{km}$ downstream. Dissolved U concentrations during the 1999 dry season in water holes along the creek were $2.88-4.75 \mathrm{mg} / \mathrm{L}$, far in excess of the $0.200 \mathrm{mg} / \mathrm{L}$ Australian water quality guideline for $\mathrm{U}$ in livestock drinking water (Lottermoser and Ashley, 2005).

\subsection{Ecosystem heath and diversity}

For areas affected by elevated concentrations of $U$, whether naturally occurring or anthropogenically introduced, there is strong interest in identifying the impact on biological communities and ecosystems. It is difficult to quantify the impact of $U$ and other associated contaminants on a natural aquatic ecosystem, which can include interrelated microscopic and macroscopic taxa (e.g., bacteria, algae, diatoms, benthic macroinvertebrates, and fish) (Ricciardi et al., 2009). Commonly, a single group of organisms is selected to represent the ecosystem response, although extrapolation to general community health can be problematic. Other stressors (e.g., climate change, physical habitat changes, invasive species, etc.) also are potentially influencing the target biological community simultaneously; toxicity studies generally investigate individual effects rather than synergistic effects of various stressors. In spite of these caveats, biological response to $U$ contamination can be evaluated by changes in species richness (number of species), taxonomic diversity of species, evenness (distribution of individuals between species), and total number of individuals. A multivariate, interdisciplinary approach is necessary for measuring ecosystem responses to elevated U. As socioeconomically important (i.e., human consumption, sport fishing) animals, toxicity in fish has received particular attention in site-specific studies, and constituents of concern have included ammonia, $\mathrm{Ni}, \mathrm{Mo}$, Se, and U. Less attention has focused on benthic invertebrates (Thomas and Liber, 2001; Peterson et al., 2002), amphibians (Schlotz et al., 2006), and other macroscopic aquatic biota. With the rapid advancement of technology for molecular biology, there have been many studies of microbial (bacterial and archaeal) diversity in Uimpacted environments.

In U-rich environments, $U$ itself may present selection pressure that favors the development of a U-tolerant microbial community. Joner et al. (2007) looked at the metabolic activity of the total microbial population in a soil slurry from Teufelsloch (France) as measured by incorporation of the DNA precursor thymidine in the presence of added uranyl acetate. The soil had elevated $U$ from coal mining, Ra and Th mining, and $U$ mining. The study compared the mine spoil topsoil ( $\sim 400 \mathrm{mg} \mathrm{U} / \mathrm{kg}$ ) and an adjacent reference soil ( $7 \mathrm{mg} \mathrm{U} / \mathrm{kg}$ ), with similar $\mathrm{pH}$ and organic matter content, and assessed the added $U$ concentration that inhibited $50 \%$ of the 
metabolic activity (EC50) in a soil slurry. The EC50 for the mine soil slurry was approximately 4 times higher than that of the reference soil slurry [30 mg U/L $(120 \mu \mathrm{M})$ in the mine slurry vs. $7.4 \mathrm{mg} \mathrm{U} / \mathrm{L}$ $(30 \mu \mathrm{M})$ in the reference slurry]. At the maximum added $U$ concentration examined [ $238 \mathrm{mg} \mathrm{U} / \mathrm{L}(1000 \mu \mathrm{M})]$, about $40 \%$ of the metabolic activity was maintained, as compared to $3 \%$ for the reference soil. It would appear that the bioavailable $U$ in the mine soils has exerted a selection pressure on the native microbial population that has pushed it, during a 150 year period of enhanced exposure, towards greater U tolerance.

In the past, ammonia was used in large quantities at $U$ mills to precipitate the extracted $U$ as ammonium diuranate [yellowcake, $\left(\mathrm{NH}_{4}\right)_{2} \mathrm{U}_{2} \mathrm{O}_{7}$ ]. Near Moab, Utah, approximately 11 million tons of UMT and tailings-contaminated soil were present in an unlined impoundment adjacent to the Upper Colorado River when operations ceased in 1984. Ammonia is the constituent of greatest ecological concern due to localized groundwater seepage into the Colorado River and its impact on populations of two endangered fish species-the Colorado pikeminnow and the razorback sucker. Two ammonia plumes are associated with the site-a deep plume beneath the tailings pile (the "legacy plume"), and a shallow plume representing seepage of tailings pore fluids (Karp and Metzler, 2006). Total ammonia concentrations as high as $1200 \mathrm{mg} / \mathrm{L}$ were observed in the river during low flow periods $\left[<140 \mathrm{~m}^{3} / \mathrm{s}\right]$; this concentration was more than two orders of magnitude greater than chronic exposure levels deemed harmful to these species. Ammonia $\left(\mathrm{NH}_{3}\right)$ is more toxic to fish than the protonated form (ammonium, $\mathrm{NH}_{4}^{+}$, the dominant species below $\mathrm{pH}$ 9.2), causing gill damage. Speciation considerations are of importance in local backwater environments that form in the Upper Colorado River adjacent to the Moab tailings pile during seasonal low-flow periods (typically August to March). These shallow, warm waters are spawning and rearing habitats for the larval and juvenile fish. Because of high primary productivity in these zones, $\mathrm{pH}$ can be as high as 9, which increases exposure to ammonia (Fairchild et al., 2002, 2005).

Changes in yellowcake production technology and more stringent environmental regulations limiting ammonia discharge should mitigate such problems in the future at $U$ milling sites. Examples from Canada illustrate the case: at the Key Lake and McClean Lake mills, ammonia is currently used for solvent extraction stripping and precipitation. Both mills operate ammonium sulfate crystallization plants and produce ammonium sulfate as a by-product; this recovery circuit thus curtails the quantity of ammonia discharged to the environment. At the Rabbit Lake mill, ammonia usage was eliminated approximately $10-15$ years ago, and extracted $U$ is now precipitated with hydrogen peroxide (H.A. Schnell, personal communication, 2010). The provincial water quality regulatory agency has developed $\mathrm{pH}$-dependent ammonia concentration objectives for surface water, with limits designed to protect aquatic life (Saskatchewan-Environment, 2006).

In the mid-1990s, $\mathrm{Ni}$ and Mo were identified during the preoperational development of the environmental impact statement for the McArthur Lake high-grade U ore body in northern Saskatchewan as key trace elements. At the Key Lake site where the ore is processed, $\mathrm{Ni}$ was elevated in the mine-dewatering effluent, and Mo was elevated in the mill effluent. Nickel concentrations as high as $20 \%$ are found in the ore; the relatively low concentrations in the mill effluent are presumably caused by liming prior to discharge. The molybdate anion remained soluble at the higher $\mathrm{pH}$ and was discharged as a soluble species, but Mo showed low toxicity for the fish species tested. Nickel releases to the environment from mine dewatering have been reduced by segregation and subaqueous disposal of Ni-rich waste rock, and by installation of a reverseosmosis plant to treat the dewatering effluent. However, Se affected fish survival in effluent-receiving waters, and was thought to have caused high mortalities in fathead-minnow (Pyle, 2000; Pyle et al., 2001; Jarrell, 2004).

Because selenate and arsenate have similar chemical characteristics to sulfate, there is the potential for bioaccumulation in the food chain, with As and Se substituting for S and being incorporated into S-bearing biomolecules such as amino acids. Elevated levels of both As and Se were found in muscle tissue of a predator fish, juvenile northern pike, which inhabited lakes downstream of the Key Lake U mill, compared to those in an upstream reference lake (Kelly and Janz, 2009). In contrast, no significant difference in Se concentration in juvenile northern pike was observed between an exposure lake and a reference lake at the McClean Lake operation U mining and milling site (Muscatello and Janz, 2009). The latter sampling involved whole body samples as compared to just the protein-rich muscle tissue. For this study, significantly elevated whole body concentrations of Se were found in juvenile fish of the three species of forage fish (white sucker, stickleback, and burbot) sampled in the exposure lake.

Selenium concentrations in plankton, periphyton, and benthic invertebrates in the exposure lake downstream of the McClean Lake operation were also significantly elevated with respect to a reference lake. The general pattern of Se accumulation was periphyton $<$ invertebrates $<$ plankton $<$ fish, indicative of trophic-level biomagnification. Elevated Se concentrations may impair fish reproduction. The Se concentrations in the sediment of the exposure lake were below a previously suggested, aquatic biota-based threshold value ( $2 \mu \mathrm{g} / \mathrm{g}$ dry weight); nevertheless, the tissue concentrations in caddisflies and forage fish exceeded the lower limit ( $3 \mu \mathrm{g} / \mathrm{g}$ dry weight) of a proposed fish-diet toxicity threshold, suggesting a potential threat to predator fish and other organisms higher in the food chain (Muscatello and Janz, 2009). Indeed, northern pike fry produced from eggs collected from females downstream of the Key Lake mill (fertilized with milt from males collected at the same site) had an increased incidence of abnormal skeletal curvature, craniofacial and fin deformities, and edema, as compared to those from a reference site. Muscle, liver, kidney, and bone Se concentrations were significantly greater in the female pike collected from the high and medium exposure sites compared to the reference site (Muscatello et al., 2006).

The Saskatchewan fish studies point to the need for broad-scale analysis of potential contaminants, and for a focus on potential food chain biomagnifications. Pyle (2000) has discussed the additional need for a broad view of potential target organisms. Whereas $U$ mine effluent is often characterized using rainbow trout in pass/fail toxicity tests, other fish species indigenous to the area may be more sensitive to $\mathrm{U}, \mathrm{Ni}$, Se, or other contaminants present.

\subsection{Decommissioning and remediation strategies}

Mechanisms by which mobility of $U$ and associated elements can be retarded in the surface and subsurface geologic environment can be generally grouped into eight categories: (1) physical barriers that limit infiltration by rainfall/snowmelt and biological intrusion, (2) subsurface precipitation of $\mathrm{U}(\mathrm{VI})$ and $\mathrm{U}(\mathrm{IV}),(3)$ microbial or plant uptake of $U$, (4) sorption of $U$ by organic matter and minerals [e.g., Fe hydroxides], (5) occlusion by clay and oxide coatings, (6) formation of U(IV) oxide surface coatings on U(VI) solids, (7) coprecipitation of $U$ with Fe- and Mn-oxides and (8) substitution in silicate clays and carbonates. These mechanisms form the basis of methods for groundwater restoration and remediation that focus on establishing the appropriate conditions for U immobilization by decreasing permeability, promoting a particular range of $\mathrm{pH}$ and redox conditions, and introducing reactants to immobilize $\mathrm{U}$. 


\subsubsection{Covers}

Earthen covers were used at the UMT sites in the US that were remediated under the UMTRA program. At Monticello, Utah (a Superfund-regulated UMT site), a polymeric geomembrane was also included in the earthen cover as part of the decommissioning. Regulatory guidance for the design of these covers recognized their multiple roles: limiting water ingress and leaching of UMT, limiting $\mathrm{Rn}$ egress to the atmosphere, limiting bio-intrusion and biouptake, and shielding the underlying wastes from wind and water erosion. Covers can also limit oxygen ingress from the atmosphere (and subsequent consumption by sulfidic tailings).

The UMTRA earthen covers of the 1980-1990s relied heavily on a compacted soil layer (CSL) for limiting permeability to $\mathrm{Rn}$ and infiltrating precipitation. The appearance of potentially deeprooted plants such as tamarisk, rabbitbrush, and Russian thistle growing on CSL covers raised concerns regarding their long-term performance. Follow-up studies by DOE involving soil moisture monitoring and in situ saturated hydraulic conductivity measurements $\left(\mathrm{K}_{\text {sat }}\right)$, conducted within about 10 years of cover placement, showed that the $\mathrm{K}_{\text {sat }}$ of these covers was several orders of magnitude greater than expected, based on values of early laboratory tests. Macropore development over the decade of environmental deployment-a process associated with the formation of plant roots channels, animal burrows, and desiccation cracks-was thought to be the cause. Selective herbicide applications can perhaps limit root intrusion, but do not represent a long-term, sustainable solution to the problem. An alternative, water-balance cover design, based on research carried out at the Monticello, Utah UMT disposal site, provides the likely basis for future UMT management plans in the US (Waugh et al., 2009). Recent work by Benson et al. (2011) suggests that conventional covers can be converted to water balance covers by ripping and blending of existing soil layers.

The Monticello cover design, shown in Fig. 5, utilizes a water storage layer ("soil sponge") consisting of fine texture soil with an animal intrusion barrier, overlying a coarse-sand capillary barrier layer (Waugh et al., 2009). The goal of this two-layer design is to retain precipitation in the soil sponge until it is seasonally returned to the atmosphere by evaporation and transpiration from a shallow-rooted plant community, thereby maintaining unsaturated conditions in the UMT below. Any percolating water that enters the coarse-sand capillary barrier is diverted laterally by an underlying 60-mil-thick, high-density polyethylene sheet. Modeling suggests that under some future circumstances, this system may not provide adequate $\mathrm{Rn}$ flux reduction. Therefore, a $0.6 \mathrm{~m}$ thick clay layer is placed below the geomembrane and directly atop the UMT (Ho et al., 2002).

\subsubsection{Groundwater remediation strategies based on $U$ reduction}

The objective of redox-based groundwater remediation is to stimulate reducing conditions by abiotic and/or biotic methods to promote reductive precipitation of uraninite or other sparingly soluble U(IV) minerals. The approach may include the use of abiotic reductants to directly reduce the mobile $\mathrm{U}(\mathrm{VI})$ aqueous complexes or to stimulate bacterial growth through addition of an electron donor, which can then directly or indirectly reduce U. These processes may be engineered into an in situ restoration scheme or be part of natural attenuation. Because many ore deposits were formed by the reducing conditions imposed by a naturally-occurring reductant such as pyrite, marcasite $\left(\mathrm{FeS}_{2}\right), \mathrm{H}_{2} \mathrm{~S}$ gas or carbonaceous material, these constituents may reinstate reducing conditions without engineered interventions provided that the reductant supply has not been exhausted during the mineralization or mining process. For example, an evaluation of post-mining cores from a South Texas U ISR operation indicated that a complete depletion of reducing capacity was found adjacent to highly

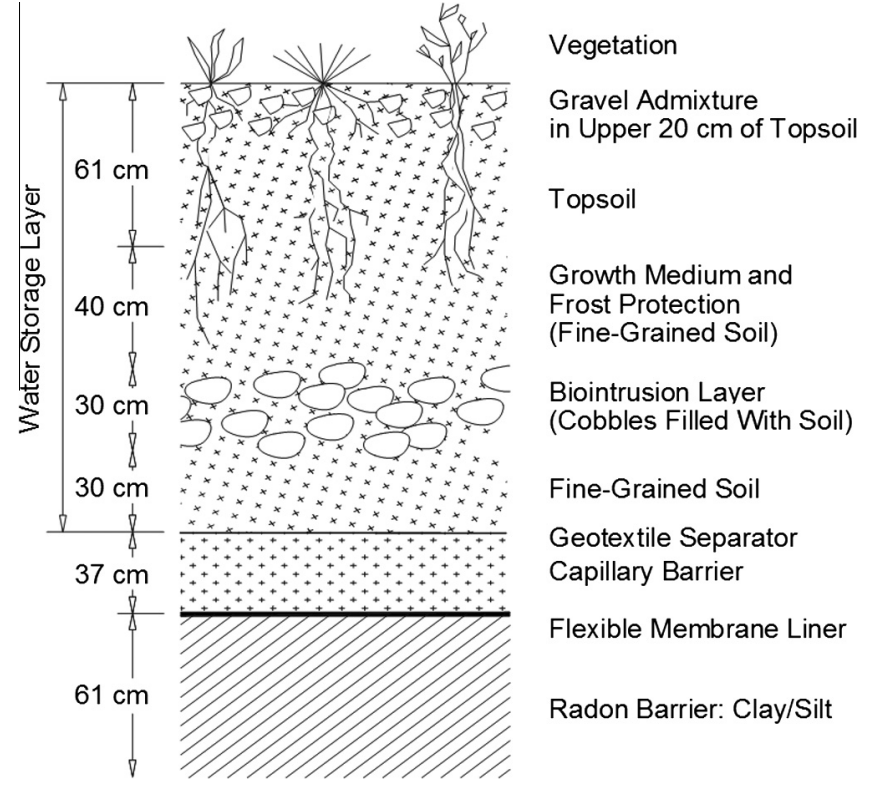

Fig. 5. Cover constructed over UMT at Monticello, Utah. The gravel mixed into the surface is an engineered design feature patterned after its natural analog-desert pavement-that helps to control wind and water erosion and aids in the establishment of vegetation (Waugh, 2004). Used with permission from U.S. Department of Energy (USDOE, 2009).

reduced zones where the lixiviant did not contact the ore (Paul et al., 1982). The preservation of post-mining reducing capacity may be sufficient to promote natural attenuation of mobilized redox-sensitive elements that have low solubilities under reducing conditions. Without characterization of the reductant or measurement of the quantity of the reductant and $U$ to be reduced, however, the capacity and kinetics of potential natural attenuation cannot be ascertained.

Reduced sulfur-based abiotic reducing agents such as ammonium bisulfite, sodium bisulfite, sodium sulfite (Grant, 1980), $\mathrm{H}_{2} \mathrm{~S}, \mathrm{Na}_{2} \mathrm{~S}$ (Deutsch et al., 1984) or sodium bisulfide (NaHS) (IAEA, 2005) are sometimes added to re-injected water at ISR operations in an effort to re-establish reducing conditions (IAEA, 2005). Deutsch et al. (1984) showed that there was only significant removal of $U$ (dropping from 44 to $1.7 \mathrm{mg} / \mathrm{L} \mathrm{U}$ ) when concentrations of $\mathrm{HS}^{-}$on the order of $10^{-2} \mathrm{M} \mathrm{HS}^{-}$were added. Reduction of uranyl to uraninite by aqueous hydrogen sulfide produces zero-valent sulfur as a reaction product (Hua et al., 2006). However, additions of $\mathrm{H}_{2} \mathrm{~S}$ to an ISR site in Wyoming following mining showed no decrease in aqueous concentrations of $\mathrm{U}, \mathrm{Mn}$, or $\mathrm{Fe}$ (Borch et al., 2012). Descostes et al. (2010) also found that U(VI)sorbed on pyrite is in close association with oxidized $\mathrm{S}$ in conjunction with only partial oxidation of $U$ and formation of $\mathrm{UO}_{2+x}$, yet other studies found the presence of Fe oxyhydroxide reaction products and no sulfur oxidation products (Eglizaud et al., 2006) or increased oxidation of both Fe and S (Wersin et al., 1994). Amorphous $\mathrm{Fe}(\mathrm{II})$-sulfide immobilized $\mathrm{U}$ as $\mathrm{U}_{3} \mathrm{O}_{8} / \mathrm{U}_{4} \mathrm{O}_{9} / \mathrm{UO}_{2}$ with polysulfide and ferric iron as reaction products, as identified by X-ray photoelectron spectroscopy (Hua and Deng, 2008). Mackinawite has been shown to immobilize dissolved $\mathrm{U}(\mathrm{VI})$ by complexation of uranyl surface complexes on oxidized regions of the Fe sulfide surface at low concentrations and a mixed $\mathrm{U}(\mathrm{IV}) / \mathrm{U}(\mathrm{VI})$ oxide phase at higher concentrations (Moyes et al., 2000; Livens et al., 2004; Hyun et al., 2012). Although sulfide-based reductants appear promising, added sulfide largely will be consumed in the reduction of other redox-sensitive constituents and also may be oxidized to $\mathrm{SO}_{4}^{2-}$ and react with $\mathrm{Ca}^{2+}$ to precipitate gypsum (Deutsch et al., 
1984). Regardless of the sulfide source, the long-term success will depend on the maintenance of sufficiently reducing conditions and resistance of reaction products to re-oxidation.

Non-sulfide reagents also have been used to promote the abiotic reduction of $U(V I)$ to $U(I V)$. Recent abiotic efforts for groundwater restoration at ISR mine sites also have included pilot studies using direct application of hydrogen gas (Cabezas et al., 2010). During post-mining operations at a leached ISR site in south Texas, approximately 100,000 standard cubic feet ( 2.8 million $\mathrm{L}$ ) of compressed hydrogen gas was injected into the leached, unconsolidated sand zone over a 2-month period. Uranium(VI) concentrations decreased from 4.2 to $0.05 \mathrm{mg} / \mathrm{L}$ in the area surrounding the injection well and to $2.0 \pm 0.3 \mathrm{mg} / \mathrm{L}$ in the area surrounding the extraction well 130 feet away. Two intermediate monitoring wells also showed significant decreases in Eh and concentrations of $\mathrm{Mo}, \mathrm{SO}_{4}^{2-}, \mathrm{Fe}, \mathrm{Mn}, \mathrm{HCO}_{3}^{-}$, and $\mathrm{Ca}$, and increases in $\mathrm{pH}, \mathrm{CH}_{4}$, and $\mathrm{S}^{2-}$ concentrations (Cabezas et al., 2010), suggesting the onset of reducing conditions. The removal mechanism is not yet well understood and may be attributed to either direct reduction by $\mathrm{H}_{2(\mathrm{~g})}$ or indirect reduction via the stimulation of microbial reduction. Although these results demonstrate the efficacy of $\mathrm{H}_{2(\mathrm{~g})}$ in lowering concentrations of constituents of concern, stringent health and safety measures must be taken in delivery of $\mathrm{H}_{2(\mathrm{~g})}$, a highly flammable and explosive gas, to the subsurface.

Reductive bioremediation has been explored as an in situ strategy for moderately contaminated sites, where complete excavation and disposal of contaminated soils and sediments is not feasible, but where the groundwater $U$ concentrations remain above the $\mathrm{MCL}$, a relatively common scenario at former UMT sites in the US. Bioremediation has been performed at a number of different pilot sites, including Oak Ridge (Tennessee), Shiprock (New Mexico), and Old Rifle (Colorado). The principle of reductive bioremediation is to stimulate native metal- and sulfate-reducing microbial communities by amending groundwater with an electron donor, such as ethanol, acetate, glucose, vegetable oil, or molasses. The objective is to reduce $\mathrm{U}(\mathrm{VI})$ directly (enzymatically) and/or indirectly by formation of reduced compounds [e.g., Fe(II), sulfide]. Anoxic conditions created by the microbial activity helps to stabilize the resulting $\mathrm{U}(\mathrm{IV})$ phases to oxidation.

The occurrence of high nitrate levels in groundwaters at $U$ milling sites, as a likely consequence of the action of ammonia-oxidizing (nitrifying) bacteria, has been discussed by Landa (2004). Finneran et al. (2002) have demonstrated the role of nitrate in influencing the mobility of $U$ in contaminated anaerobic sediments from the Shiprock UMT site. Soluble nitrate in groundwaters can inhibit the microbial reduction of $\mathrm{U}(\mathrm{VI})$ to $\mathrm{U}(\mathrm{IV})$ by providing an energetically preferred electron acceptor for microbial respiration. Thus, removal of soluble $\mathrm{U}(\mathrm{VI})$ from groundwater as an insoluble $\mathrm{U}(\mathrm{IV})$ precipitate is not expected to commence until nitrate is depleted in the system. If $U$ reduction is the targeted mechanism for the bioremediation of an aquifer, then the rate and extent of denitrification reactions in the aerobic source area and upgradient-plume zones are critical concerns. In arid zones such as Monument Valley, Arizona, the planting of deep-rooted shrubs such as native saltbush (Atriplex canescens) to extract nitrate from the plume, and the stimulation of native denitrifying bacterial communities by the addition of readily degradable carbon sources such as ethanol have been investigated as methods to eliminate nitrate from the groundwater system (Jordan et al., 2008). Also of note is that the presence of nitrate in groundwater systems in which insoluble U(IV) already is present can lead to the mobilization to solution of $\mathrm{U}(\mathrm{VI})$ due to the abiotic oxidation of $\mathrm{U}(\mathrm{IV})$ by dentrification intermediate products (Finneran et al., 2002; Senko et al., 2002).

Although the long-term efficacy of biostimulation has yet to be demonstrated, there has been considerable success in characterization of key processes in the pilot-scale experiments. The biostimulation experiments using acetate as an electron donor at the Old Rifle UMT site will be discussed as a case study for U bioremediation, chosen for its interdisciplinary approach to understanding biological (through metagenomics and proteomics, the study of genetic and protein material obtained from environmental samples), chemical, isotopic, and hydrological processes, as well as for numerical model development.

The Old Rifle site has a shallow, unconfined alluvial aquifer with $\mathrm{U}$ concentrations between 0.1 and $0.4 \mathrm{mg} / \mathrm{L}(0.4-1.8 \mu \mathrm{M})$, circumneutral $\mathrm{pH}$, and low but measurable amounts of dissolved oxygen. The groundwater exhibits elevated concentrations of sulfate and carbonate alkalinity, is typically near equilibrium with calcite, has low nitrate concentrations, and has variable concentrations of dissolved Fe. In the first series of biostimulation experiments, acetate stimulated primarily Geobacter species, producing substantial amounts of dissolved $\mathrm{Fe}(\mathrm{II})$ and a concomitant decrease in dissolved $\mathrm{U}(\mathrm{VI})$ to below the target concentration for $\mathrm{U}$ (Anderson et al., 2003). Metal reduction was followed by a shift in the dominant microbial population to sulfate reducers (e.g., Desulfobacter species) and significant sulfate reduction, resulting in complete consumption of acetate and a partial rebound of $\mathrm{U}(\mathrm{VI})$ concentrations in the groundwater. Subsequent studies have utilized alternate injection schemes including short, pulsed injections of acetate as well as a longer duration injection with higher acetate concentrations to overcome electron donor limitation during sulfate reduction (Yabusaki et al., 2010). Interestingly, increased sulfate reduction produced longer-term $U$ removal after acetate injection was terminated when acetate was not limiting during the stimulation phase; reduced Fe-S phases are likely to have played an important role in this behavior.

Thermodynamically, Fe(III) phases are expected to be reduced prior to the onset of sulfate reduction. Initially, this argument was in agreement with the transition between $\mathrm{Fe}$ and sulfate reduction in the field experiments. However, laboratory column studies with Rifle sediment in which the iron phases were predominantly goethite and $\mathrm{Fe}(\mathrm{III})$ phyllosilicates showed that bioreducible $\mathrm{Fe}(\mathrm{III})$ phases were present past the onset of sulfate reduction (Komlos et al., 2008b). This observation was supported by field experiments in which excess acetate was injected; simultaneous $\mathrm{Fe}(\mathrm{III})$ and sulfate reduction were observed, and reducible $\mathrm{Fe}(\mathrm{III})$ remained in the sediments even after 110 days of acetate injection (Williams et al., 2011). These results suggest that microbial community dynamics, metabolism, and the rates and mechanism of $\mathrm{U}(\mathrm{VI})$ reduction are more complex than the simple thermodynamics approach suggests. Accurate representation of microbial processes in numerical models will have to include process and growth kinetics, community dynamics, nutrient limitation effects, and a strong link to aqueous speciation and mineralogy.

Genetic and proteogenomic analyses before, during, and after biostimulation also have revealed additional complexity during $\mathrm{U}(\mathrm{VI})$ reduction. Transcription of dissimilatory sulfate reduction genes ( $d s r$ ) during biostimulation was used to measure in situ activity of different sulfate reducing bacteria (SRB), and showed that Desulfobacteraceae were more responsive to the acetate injection than other SRB initially present in the aquifer (Miletto et al., 2011). Geochemical and genetic analyses of post-stimulation groundwater showed a surprising decrease in $\mathrm{U}(\mathrm{VI})$ after acetate injection ceased, possibly because of the shift in community structure from SRB to Firmicutes and subsequent sorption on biomass (N'Guessan et al., 2008). In addition, proteogenomic monitoring of Geobacter species in groundwater during the early bioreduction phase showed that even within the Geobacter family, multiple species and strains were present, and community composition evolved with time (Wilkins et al., 2009). The metaproteome (proteins recovered from the mixed microbial community in the Rifle aquifer groundwater) was dominated by central-metabolism and 
energy-generation enzymes such as ATP synthase, TCA cycle proteins, and acetate-metabolizing enzymes, although many proteins were unable to be matched to a pathway because of database limitations. Additional metagenomic analysis showed that fermentation may be an important pathway during biostimulation and has an important role in carbon, hydrogen, and sulfur cycling (Wrighton et al., 2012). Increasingly subtle changes and depth in community structure and metabolic activity are expected to be accessible using proteogenomic techniques as the methods and databases improve in the future.

Substantial mineralogical changes that occur upon biostimulation can be important in the management and success of a bioremediation project. As acetate was metabolized by the microbial community at Rifle, biomass and dissolved inorganic carbon were produced. The increase in alkalinity tended to desorb $U(V I)$ from the mineral surfaces, releasing $U$ into the groundwater. In addition, when excess acetate was injected into the aquifer, $\mathrm{U}(\mathrm{VI})$ was removed even during sulfate reduction, and $\mathrm{Fe}(\mathrm{II})$-sulfide minerals, siderite $\left(\mathrm{FeCO}_{3}\right)$, and calcite precipitated (Williams et al., 2009). Whereas Fe-S phases can act as a redox buffer in the system, potentially shielding the reduced U(IV) from re-oxidation, they can also decrease aquifer permeability and clog injection wells, preventing acetate delivery (Li et al., 2009; Williams et al., 2011).

During acetate amendment of the groundwater, several other elements in addition to $U$ exhibited redox transformations. Vanadate, another element of concern at the site, was reduced to a sparingly soluble V(IV) phase, and removal persisted for at least 2 years (Yelton et al., 2013), indicating that bioremediation was effective for both U and V. Dissolved selenate and selenite were reduced to elemental selenium nanoparticles that were closely associated with cells (Williams et al., 2013). Unlike V and Se, As was mobilized into the groundwater during biostimulation (increased from a background of $1 \mu \mathrm{M}$ to $8 \mu \mathrm{M}$ ), and thioarsenic species were detected during sulfate reduction (Stucker et al., 2013). The mobilization of As into the groundwater during acetate amendment and sulfate reduction may pose a challenge to $U$ bioremediation.

Several sophisticated reactive transport models (RTMs) have been developed for the Rifle site, merging the hydrological, biological, and geochemical data collected during the biostimulation experiments, and utilizing a high performance computing approach (Yabusaki et al., 2007, 2010, 2011; Fang et al., 2009; Li et al., 2009). The models include hydrodynamics, thermodynamics of terminal electron acceptors, mineral precipitation, $U$ adsorption, and kinetics of $\mathrm{U}$ and $\mathrm{SO}_{4}^{2-}$ reduction. Sensitivity analyses show that the model is most sensitive to groundwater flow velocity, as well as $\mathrm{U}$ and $\mathrm{SO}_{4}^{2-}$ bioreduction rates. In addition, $\mathrm{RTM}$ s have been used to test the impact of local heterogeneity (on the order of tens of centimeters) on simulations of field-scale U bioreduction rates, determining that local hydraulic conductivity and $\mathrm{Fe}(\mathrm{III})$ sediment content have large effects on the field-scale behavior of dissolved $\mathrm{U}(\mathrm{VI})$ (Li et al., 2011). The interactions of microbial communities, biomass sorption, and subtleties in rate expressions for $U$ and $\mathrm{SO}_{4}^{2-}$ reduction are key areas where, in general, $\mathrm{RTMs}$ can be improved. In addition, oxidative processes also should be included as thermodynamic constants and rate expressions become available.

Bioremediation is being explored as a possibly cost-effective way to treat many UMT legacy sites. However, several key issues must be overcome before the strategy is successful long-term at a large scale: (1) optimization of $\mathrm{U}(\mathrm{VI})$ removal during $\mathrm{Fe}(\mathrm{III})$ and $\mathrm{SO}_{4}^{2-}$ reduction phases, (2) maintaining aquifer permeability during biostimulation, and (3) preventing reoxidation of reduced $\mathrm{U}(\mathrm{IV})$ phases in the subsurface. Increases in water table level driven by changes in river stage have been shown to increase the dissolved oxygen content in the aquifer by trapping atmospheric $\mathrm{O}_{2}$ in sediment micropores, providing additional oxidizing potential to already suboxic to oxic native groundwater at Rifle (Yabusaki et al., 2010). In addition, the optimal bioremediation strategy will depend heavily on site-specific characteristics such as groundwater flow, alternate electron acceptors, response of native microbial community to electron donors, presence of potential oxidants, and seasonal cycles. The development of reactive transport models is expected to facilitate remediation design and site management practices.

\subsubsection{Non-redox strategies}

Non-redox restoration strategies for U-contaminated aquifers have focused largely on: (1) permeable reactive barriers to promote sequestration of mobile $U$ complexes via sorption processes, (2) flushing to affect the physical desorption of contaminants, and (3) subsurface aquifer amendments to precipitate $\mathrm{U}(\mathrm{VI})$ minerals.

4.6.3.1. Permeable reactive barriers. Permeable reactive barriers (PRBs) have been used for decades to promote the in situ passive sequestration of trace metals such as $U$ in shallow, contaminated aquifers (e.g., Naftz et al., 2000). A series of PRBs have been evaluated on three classes of potential materials (phosphate, zero valent iron, and ferric iron) for treatment of $U$ in groundwater (median $U$ concentrations $=840 \mu \mathrm{g} / \mathrm{L}$ ) in the aquifer beneath a U-Cu heap leaching and $U$ up-grader site in Fry Canyon, Utah (Naftz et al., 2000). Zero-valent iron foam pellets removed $99.9 \%$ of incoming $\mathrm{U}$, whereas amorphous ferric oxyhydroxide mixed with $9.5 \mathrm{~mm}$ ( $3 / 8$ inch) gravel ( $2 \% \mathrm{Fe}$ ) and pelletized bone-char phosphate each removed over $70 \%$ of $U$ from solution. The use of the pelletized bone-char is based on the premise that apatite may release phosphate and react with dissolved $U$ to form low-solubility secondary uranyl phosphates (Arey et al., 1999) or surface complexes at low U loadings (Fuller et al., 2002). However, the mechanism of removal for the pelletized bone-char apatite collected from the Fry Canyon PRB was evaluated using X-ray spectroscopy and found to be most likely surface complexation (Fuller et al., 2003). Only when sorbed concentrations exceeded $5500 \mu \mathrm{g} \mathrm{U}(\mathrm{VI}) / \mathrm{g}$ in the absence of dissolved carbonate did the uranyl-phosphate mineral chernikovite $\left(\mathrm{UO}_{2} \mathrm{HPO}_{4} \cdot 4 \mathrm{H}_{2} \mathrm{O}\right)$ precipitate (Fuller et al., 2003).

Zero-valent iron PRBs also were effective at lowering dissolved concentrations of As, $\mathrm{Mn}, \mathrm{Mo}, \mathrm{Se}, \mathrm{U}, \mathrm{V}$ and $\mathrm{Zn}$ in groundwater close to a UMT impoundment near Durango, Colorado. The decreases in groundwater concentrations could be explained by the precipitation of $\mathrm{UO}_{2}, \mathrm{~V}_{2} \mathrm{O}_{3}, \mathrm{As}_{2} \mathrm{~S}_{3}, \mathrm{ZnS}, \mathrm{FeS}_{2}, \mathrm{FeMoO}_{4}$ and $\mathrm{MnCO}_{3}$ (Morrison et al., 2002), which would imply reducing conditions. The Uremoval mechanism within a zero-valent iron PRB installed at a former $U$ milling site in Monticello, Utah was cited as reductive precipitation due to corrosion of $\mathrm{Fe}^{0}$ (Morrison et al., 2001). Some researchers also have found that reductive precipitation occurs upon reaction of uranyl nitrate solutions with zero-valent iron (Gu et al., 1998). However, a critical review regarding the mechanisms of $U$ removal from solution by zero-valent iron has provided compelling evidence that direct reduction of redox-active contaminants may not necessarily be the primary removal mechanism. Noubactep (2008) argued that $\mathrm{Fe}^{0}$ corrosion products including $\mathrm{Fe}(\mathrm{II})$ and $\mathrm{H}_{2}$ (g) can indirectly catalyze reducing reactions, whereas iron oxidation products may serve as co-precipitates or adsorbents for contaminants.

Adsorption of $\mathrm{U}(\mathrm{VI})$ onto iron oxides has been shown to be effective at decreasing dissolved $U$ concentrations in solution (Hsi and Langmuir, 1985). However, the extent of adsorption largely depends on $U$ speciation. Recent studies examining the effect of $\mathrm{Ca}$ and carbonate on $\mathrm{U}$ adsorption to goethite reveal that neutral to slightly acidic $\mathrm{pH}$ values (about 5 ) and limited quantities of dissolved $\mathrm{Ca}(<0.2 \mathrm{mM})$ are optimal for $U$ adsorption suggesting that $\mathrm{U}(\mathrm{VI})$ adsorption decreases under conditions that favor the formation of aqueous complexes $\mathrm{Ca}_{2} \mathrm{UO}_{2}\left(\mathrm{CO}_{3}\right)_{3}$ and $\mathrm{CaUO}_{2}\left(\mathrm{CO}_{3}\right)_{3}^{2-}$ (Stewart et al., 2010). However, as concentrations increase in solu- 
tion, $U$ may become incorporated within the hematite structure as the uranate species ( $U^{6+}$ without axial $U-O$ bonds) until the point of saturation, beyond which, discrete crystalline $\mathrm{U}(\mathrm{VI})$ precipitates, such as schoepite, will form (Duff et al., 2002). As with all redox sensitive elements, the uptake mechanism is sensitive to changes in redox conditions; however, in the presence of $3 \mathrm{mM} \mathrm{Fe}(\mathrm{II})$, the $\mathrm{U}$ incorporated into $\mathrm{Fe}(\mathrm{III})$ (hydr)oxide structures has been shown to be stable (Stewart et al., 2009).

For deeper deposits, some researchers have explored the injection of solids into the subsurface to create reactive zones that may sequester $U$ and ${ }^{226} \mathrm{Ra}$. Injected grey cast iron (containing impurities such as graphite) has been shown to be slightly less effective than nano-scale iron at removing $U$ in column studies. The addition of $\mathrm{MnO}_{2}$ increased the efficiency of the uptake process under slightly reducing conditions by promoting the oxidation of $\mathrm{Fe}^{2+}$ to $\mathrm{Fe}(\mathrm{III})$ oxides only on the surface of $\mathrm{MnO}_{2}$ rather than in the bulk pore spaces as would occur under oxidizing conditions. The $\mathrm{MnO}_{2}$ also occluded ${ }^{226} \mathrm{Ra}$ and, to a lesser extent, $\mathrm{U}$ (Burghardt and Kassahun, 2005). However, like zero-valent iron PRBs, a loss of permeability may result from the formation of voluminous Fe(III) oxide phases under aerobic conditions.

4.6.3.2. Flushing to affect the physical desorption of contaminants. The most common physical restoration strategies employed at ISR operations include: (1) the use of a "groundwater sweep," and (2) pump-and-treat and recirculation. Groundwater sweep involves pumping several pore-volumes of water from the mined area to draw water from the surrounding aquifer into the mining zone to displace leaching solutions. The groundwater sweep is the simplest method in which both chemical constituents and groundwater are pumped from the mined zone and sent to evaporation ponds. The disadvantage is the large consumptive use and the need for large land surface areas for the wastewater storage or pond facilities (Catchpole et al., 1984). Groundwater quality usually improves with the groundwater sweep, although it is typically insufficient and uneconomical for complete restoration (Davis and Curtis, 2007). Laboratory studies and operator experiences have shown that sweeping inhibits restoration for redox sensitive elements because the clean groundwater acts as a mild leaching agent and causes concentrations of $\mathrm{U}, \mathrm{Se}$, and Mo to remain elevated (Deutsch et al., 1985).

A modification of the groundwater sweep involves the addition of a treatment circuit after the first pore-volume of water is extracted. The pumped groundwater may be treated by reverse osmosis (RO), electrodialysis (ED) membrane systems, (IAEA, 2005) or ion exchange (Catchpole et al., 1984). In the RO circuit, the groundwater is filtered and the $\mathrm{pH}$ is lowered (to prevent $\mathrm{CaCO}_{3}$ precipitation) before passing through the RO membranes (Davis and Curtis, 2007) containing cellulose acetate derivatives (Deutsch et al., 1985). The purified water (RO permeate) is then recirculated in the mined zone until restoration goals are achieved. The concentrated brine byproduct of the treatment that is about $25-35 \%$ of the feed volume, is sent to a settling pond, dried for disposal at a licensed facility, or injected into a deep well (Pelizza, 2008). Conceivably, as the "clean groundwater," which contains little dissolved constituents, is recirculated through the mined aquifer zone, it ultimately may drive dissolution of subsurface minerals as the system attempts to reach equilibrium or cause further dissolution of U-bearing solids by contact with aerated return water. The effectiveness of these pump-and-treat methods is discussed below, with reference to several case studies.

Catchpole et al. (1984) presented case studies on restoration processes that met regulatory requirements following bicarbonate-carbonate-oxygen ISR using groundwater sweep in combination with recirculation following $\mathrm{RO}$, ion exchange and
EDR at Bison Basin (Freemont County, Wyoming), Reno Creek (Campbell County, Wyoming), and Leuenberger (Powder River Basin, Wyoming), respectively (Catchpole et al., 1984). Following ISR mining, inorganic carbon, $\mathrm{Ca}, \mathrm{Cl}, \mathrm{Mn}, \mathrm{U}$ and ${ }^{226} \mathrm{Ra}$ remained elevated above baseline at Bison Basin; however, restoration goals were achieved after circulating about six pore volumes of RO-treated water through the aquifer (Catchpole et al., 1984). All constituents at Reno Creek were restored to below or within baseline levels, except for ${ }^{230} \mathrm{Th}$ and $U$, and the Leuenberger restoration process achieved target restoration values of most elements, except for ${ }^{226} \mathrm{Ra}(350 \mathrm{pCi} / \mathrm{L}$ or $13 \mathrm{~Bq} / \mathrm{L}$ compared to baseline average of $185 \mathrm{pCi} / \mathrm{L}$ or $6.8 \mathrm{~Bq} / \mathrm{L}$ ) (Catchpole et al., 1984). Following a pilot $\mathrm{H}_{2} \mathrm{O}_{2} / \mathrm{NaHCO}_{3}$ injection in the Westwater Canyon of the Morrison Formation near Crownpoint, New Mexico, groundwater constituents were reported as meeting restoration goals (except for Mo) by first removing 1.5 pore volumes of mine-impacted groundwater from the mining zone into a disposal pond and then implementing a groundwater sweep coupled with ion exchange-water softeningRO and reinjection (Vogt et al., 1984). Although Mo was assumed to be an artifact of the limited leaching time of the pilot study and would not be expected to cause difficulty in a commercial operation (Vogt et al., 1984), the use of Mo-precipitating agents such as $\mathrm{Ca}^{2+}$ or reducing agents such as $\mathrm{Fe}^{2+}$ could be used to lower concentrations of Mo during restoration (Strom and Vogt, 1987).

There are a number of studies that suggest that restoration following ISR may be challenging. Two reviews of post-mining groundwater quality data from former ISR sites in South Texas reported to the Texas Commission on Environmental Quality (TCEQ) have indicated difficulties in reaching restoration goals for $\mathrm{U}, \mathrm{SO}_{4}^{2-}$, and Se when pump-and-treat (e.g., RO, ED) and reinjection restoration processes were used (Darling, 2008; Hall, 2009). Although eventually restoring aquifers to regulatory requirements, post-restoration monitoring at the ISR site at Highland, Wyoming initially revealed increasing concentrations of $\mathrm{Fe}, \mathrm{Mn}, \mathrm{As}, \mathrm{Se}, \mathrm{Ra}$, and U over time (Davis and Curtis, 2007). Likewise, at Crow Butte, Nebraska, post-ISR monitoring showed elevated concentrations of Mo, Ra, U, and V following restoration; the site at Ruth, Wyoming also experienced rebounding concentrations of $U$, As and Ra after an initial decline (Davis and Curtis, 2007) in concentrations following ISR restoration. Field operations in the Powder River Basin, Wyoming with an ammonium carbonate lixiviant also have shown steady increases in the groundwater TDS, Se, $\mathrm{U}, \mathrm{SO}_{4}^{2-}$, and $\mathrm{NH}_{4}^{+}$ (Osiensky et al., 1988) in the 10 months following restoration. Although post-mining and restoration groundwater quality data are scarce, laboratory studies on Wyoming ore leached with ammonium bicarbonate also indicated post-leach release of substantial concentrations of $\mathrm{U}(16-26 \mathrm{mg} / \mathrm{L}), \mathrm{NH}_{4}^{+}(140-190 \mathrm{mg} / \mathrm{L})$, $\mathrm{HCO}_{3}^{-}$(60-100 mg/L), and Se (0.1-0.2 mg/L) (Grant et al., 1985). Geochemical modeling by Davis and Curtis (2007) suggested that mobility of these contaminants may be due to either mixing and diffusion of water from lower permeability zones or the increased oxidation of the system over time. Furthermore, there may be differences in restoration time required for each element. An analysis of post-mining and pre-mining ISR water quality from a research site near the southwestern edge of the Powder River Basin suggested that the reaction rates for the precipitation of uraninite during restoration is faster than that of ferroselite, which may control Se concentrations. Modeling simulations showed that uraninite may be restored or reach steady state within 5 years, whereas achieving steady state for ferroselite would take longer (Johnson and Neumann, 1986). As such, the return of reducing conditions and restoration success may not be complete in short time frames, and therefore, long-term stabilization and monitoring will be required to demonstrate the effectiveness of remediation schemes. 
4.6.3.3. Subsurface aquifer amendments to precipitate $U(V I)$ minerals. Recent research has focused on forcing precipitation of $\mathrm{U}(\mathrm{VI})$ solids by amending the groundwater with specific chemical treatments under oxidizing conditions. In nature, stable $\mathrm{U}(\mathrm{VI})$ minerals may form, resulting in equilibrium concentrations of $U$ in the aqueous phase below the current $30 \mu \mathrm{g} / \mathrm{L}$ groundwater MCL. For example, an oxidized weathered bedrock aquifer associated with the Coles Hill, Virginia U deposit contains less than $15 \mu \mathrm{g} / \mathrm{L}$ dissolved $\mathrm{U}$. In this zone, it is thought that stable $\mathrm{U}(\mathrm{VI})$ phosphate minerals control the U concentrations (Jerden and Sinha, 2003), demonstrating the long-term potential for natural attenuation of $U$ in apatiterich environments. Surface precipitation also could provide long-term, post-adsorption $U$ fixation during natural attenuation. Initially, $\mathrm{U}(\mathrm{VI})$ may be immobilized by adsorption onto iron oxide surfaces, but as aging proceeds, $U$ may be released to form surface precipitates. For example, downstream of a $U$ ore deposit at Koongarra, Australia, U forms nanocrystalline saléeite $\left[\mathrm{Mg}\left(\mathrm{UO}_{2}\right)_{2}\right.$ $\left.\left(\mathrm{PO}_{4}\right)_{2} \cdot 10 \mathrm{H}_{2} \mathrm{O}\right]$ and (meta)torbernite $\left[\mathrm{Cu}\left(\mathrm{UO}_{2}\right)_{2}\left(\mathrm{PO}_{4}\right)_{2} \cdot 8 \mathrm{H}_{2} \mathrm{O}\right]$ surface precipitates within veins of fine-grained goethite and hematite (Murakami et al., 1997). These nanocrystals were found in contact with groundwater containing concentrations as low as $10-30 \mu \mathrm{g} / \mathrm{L}$ $\mathrm{U}$, below the saturation limit for these uranyl phosphates. Phosphorous is thought to have been sequestered initially by ferrihydrite, and later released as the ferrihydrite aged under oxidizing conditions (Murakami et al., 1997). The control of $U$ concentrations by autunite, however, is limited to a $\mathrm{pH}$ range 6.2-7.3 and is not effective above atmospheric $\mathrm{CO}_{2}$ partial pressures (Tokunaga et al., 2009). Phosphate-induced immobilization mechanisms were evaluated under laboratory conditions in the presence and absence of goethite. At added concentrations ranging from 12 to $24 \mathrm{mg} / \mathrm{L} \mathrm{U}$ $(50-100 \mu \mathrm{M})$ and $9 \mathrm{mg} / \mathrm{L} \mathrm{PO}_{4}^{3-}(130 \mu \mathrm{M})$, chernikovite forms whether or not goethite is present. Adsorption was the dominant removal mechanism when phosphate concentrations dropped below $1.4 \mathrm{mg} / \mathrm{L}$ or when $\mathrm{PO}_{4}^{3-}$ was in large excess of the total $\mathrm{U}$. Goethite, however, tends to provide a sink for phosphate by adsorption and thus limits the formation of $U$ phosphate precipitates (Singh et al., 2010). Successful immobilization depends on the type of phosphate compound applied. For example, the addition of trisodium trimetaphoshate and dodecasodium phytate to high organic content soils can result in increased aqueous $U$ concentrations due to dispersion of U-organo-mineral colloids or complexes (Majs, 2011). As with any amendment, site-specific studies must be conducted to ascertain potential efficacy.

The use of a $\mathrm{V}$ solution has also been evaluated as a potential aquifer amendment for the removal of $U$. The addition of potassium metavanadate $\left(\mathrm{KVO}_{3}\right)$ to solutions containing dissolved $\mathrm{U}(\mathrm{VI})$ demonstrate that carnotite $\left[\mathrm{K}_{2}\left(\mathrm{UO}_{2}\right)_{2} \mathrm{~V}_{2} \mathrm{O}_{8}\right]$ is likely to form (Tokunaga et al., 2009). Geochemical modeling predicts that if carnotite and tyuyamunite form in the presence of $0.115 \mathrm{mg} / \mathrm{L}(1 \mu \mathrm{M})$ vanadate, then $U$ concentrations fall below the MCL over a broader range of $\mathrm{pH}$ than for the precipitation of autunite. However, it should be noted that the precipitation of either carnotite or tyuyamunite is not effective above $\mathrm{pH}$ 7.5. Furthermore, the minerals also are susceptible to dissolution in the presence of more dilute groundwater containing low $\mathrm{P}, \mathrm{V}$ and $\mathrm{U}$ concentrations (Tokunaga et al., 2009). Addition of $\mathrm{P}$ and $\mathrm{V}$ subsurface amendments provide potential mechanisms for the immobilization and stabilization of $U$ as a $U(V I)$ solid phase resulting in low aqueous concentrations of $U$.

Although the use of chemical amendments for precipitation of $\mathrm{U}(\mathrm{VI})$ solids is promising, as with the use of redox-active amendments, the products are susceptible to interaction with regional groundwaters which may render the engineered remediation method ineffective over the long term. Kinetic limitations should be considered in the overall design of the remediation scheme. These studies, however, provide impetus for further research into groundwater remediation strategies. It would stand to reason that implementing a reductant-based remediation scheme in a subsurface aquifer where oxidizing groundwater conditions prevail on a regional scale would be difficult. Likewise, using an oxidizing adsorbent material such as $\mathrm{Fe}(\mathrm{III})$ oxide in a naturally reducing aquifer likely would result in the eventual reductive dissolution of the Fe oxides, and subsequent release of immobilized U. As such, it is important to consider the site-specific attributes of a contaminated aquifer when applying remediation schemes.

\subsubsection{Plant uptake of radionuclides}

Soil-to-plant transfer of radionuclides is typically reported as a transfer factor or concentration ratio, defined as the ratio of the radioactivity concentration in plant tissue to that in the soil (each expressed in similarly based units, such as Bq/kg dry weight). ${ }^{226} \mathrm{Ra}$ is generally the radionuclide of greatest concern when considering radionuclide uptake by plants at $U$ mining and milling sites; transfer factors for ${ }^{226} \mathrm{Ra}$ and other radioactive and non-radioactive contaminants, most often developed for agricultural soils, must be used with caution at such sites. For typical agricultural scenarios, soil-to-plant transfer factors can be used to predict the radionuclide levels one might expect to see in edible and non-edible plant tissues [see, for example, (Tagami and Uchida, 2009) for ${ }^{226} \mathrm{Ra}$ ]. Such relationships also can be experimentally established for rooting substrates other than typical soils (e.g., UMT) where chemical processing can change the bioavailability of radionuclides or trace elements [see, for example, (Soudek et al., 2007) for flora growing at a UMT site in the Czech Republic]; studies such as these can be used to assess possible food chain exposures to consuming humans, domesticated animals, and wildlife, as well as to identify plants that may have utility in phytoremediation of such sites. Phytoremediation-or more specifically here "phytoextraction"-uses terrestrial plants to remove contaminants from soils into harvestable plant biomass to decontaminate the soil over time with multiple cropping.

Soils and waters in the vicinity of past $U$ mining and heap leaching operations at Cunha Baixa, Portugal have elevated levels of ${ }^{238} \mathrm{U}$ series radionuclides. Well water tapping the shallow aquifer shows elevated concentrations of ${ }^{238} \mathrm{U},{ }^{226} \mathrm{Ra}$ and ${ }^{210} \mathrm{Po}$ that correlated inversely with pH (Carvalho et al., 2009a). Carvalho et al. (2009b) examined radionuclide uptake by potatoes (Solanum tuberosum) irrigated with waters from two shallow wells in this region. The plant/water concentration ratio for ${ }^{226} \mathrm{Ra}\left[\mathrm{CR}_{\mathrm{w}}=\right.$ (radionuclide concentration in the plant tissue of concern in $\mathrm{Bq} / \mathrm{kg}$ dry weight basis)/ (radionuclide concentration in the water in $\mathrm{Bq} / \mathrm{L}$ )] for the tubers of potatoes growing on soils with different ${ }^{226} \mathrm{Ra}$ concentrations ( $\sim 1200$ and $800 \mathrm{~Bq} / \mathrm{kg}$ ) showed similar values (4.6 and 4.8 ) for the two well waters $(\sim 1.200$ and $2.700 \mathrm{~Bq} / \mathrm{L})$. Thus the uptake of ${ }^{226} \mathrm{Ra}$ by the potato tubers was proportional to the concentration of this radionuclide in the irrigation water. Uptake of Ra into the plant tissue occurs both from the soil (exchangeable fraction and readily soluble fractions) and from the irrigation water, but the delivery of water-soluble ${ }^{226} \mathrm{Ra}$ to the root zone dominates that available from the soil in this irrigated system.

For phytoextraction of a soil or related earth material to be practical, contaminants must be (1) taken-up in significant quantity by the plants in question, and (2) translocated to harvestable, above-ground tissue. An optimal plant species for phytoextraction will have a high transfer factor to aboveground tissue and produce sufficient aboveground biomass to provide for the incremental removal of significant amounts of the contaminant at each harvest. Experimental work to address issue (1) includes testing of inoculation and colonization of roots by arbuscular mycorrhizal (AM) fungi as a possible means of increasing crop uptake. Recent studies in China on UMT showed AM fungi to increase root 
uptake of $U$, but to also decrease translocation to shoots (Chen et al., 2008). This situation is good from a perspective of a lower concentration of $U$ in the aboveground tissue being incorporated into the food chain by grazing animals, but bad in terms of phytoextraction of $\mathrm{U}$ from the substrate tailings. Work by Soudek et al. (2007) on trees growing at a UMT site is illustrative of issue (2). The leaves of birch trees (Betula pendula) at this UMT site were shown to take up quantities of ${ }^{226} \mathrm{Ra}$ [up to $0.4 \mathrm{~Bq} / \mathrm{g}$ dry weight $(11 \mathrm{pCi} / \mathrm{g})]$ greater than those of other trees at the site. However, as fallen leaves are not readily contained, the potential exists for their dispersal and the resultant secondary contamination of off-site properties, especially where stringent ${ }^{226} \mathrm{Ra}$ cleanup standards [typically $0.2 \mathrm{~B} / \mathrm{g}(\sim 5 \mathrm{pCi} / \mathrm{g})$ for soil] are in place. Future phytoextraction investigations at $U$ mining and milling sites probably will focus on AM fungi, the search for hyperaccumulator plant species, and the possible use of soil amendments such as citric acid to enhance radionuclide uptake and translocation (compare to Huang et al., 1998). Recent estimates, based upon ${ }^{226}$ Ra uptake from UMT and potting soil mixtures by two species of genus Lupinus, suggests that the time required for phytoextraction is too long for practical purposes; recent investigations by Soudek et al. (2010) showed that it would take about 130 years to get to the $0.2 \mathrm{~Bq} / \mathrm{g}$ target clean-up level.

In most cases, the assumption is that external and internal radiation doses to tissues of plants growing on UMT and $U$ mine spoils are below levels that cause somatic or genetic effects. However, studies of tufted vetch (Vicia cracca), a forage plant growing on UMT and Ra production wastes at the Otvally site in Vodnyi, in the Komi Republic of Russia (Taskaev et al., 2003) showed that internally deposited ${ }^{226} \mathrm{Ra}$ contributes a major fraction of the dose. That dose can be above the threshold for biological effects; observed effects that correlated directly with the calculated absorbed dose for seeds at the site include the frequency of chromosome aberrations in the meristematic root-tip cells of seedlings, the germination rates of seeds, and the survival rates of sprouts of seeds (Evseeva et al., 2009).

Sequential extraction procedures are often used to assess potentially labile forms of radionuclides and trace elements at $U$ mining site soils and UMT [e.g., (Joner et al., 2007; Štrok and Smodiš, 2010)]. However using these data as measures of the environmentally mobile fraction (plant availability, release from sediments to pore water) is problematic. Emerging techniques such as diffusive gradient in thin film probes (DGT) which use $\mathrm{MnO}_{2}$ as a binding resin may be useful in more directly assessing the mobility of ${ }^{226} \mathrm{Ra}$ and other metals in soils and sediments at these sites. At a test site in Belgium, where ${ }^{226}$ Ra-rich effluents from phosphate rock processing facilities were released to local waterways, Gao et al. (2010) found the Ra recoverable by DGT probes placed in downstream sediments to roughly correlate with labile fractions (exchangeable and carbonates, Fe- and Mn-oxides) measured by selective extraction.

Although the focus of this section is on living plant biomass, it is interesting to note that non-living plant material can play a role in U-immobilization. Such dead biomass in sediments can form the organic-rich anoxic zones of importance in roll-front $U$ deposits. $\mathrm{Xu}$ et al. (2004) examined carbonized wood fragments from a sandstone-hosted roll-type deposit in northwestern China with electron microscopy. Based upon replacement patterns observed, the investigators postulated a two-step process in which: (1) $\mathrm{U}(\mathrm{VI})$ in groundwater is sorbed by fungal spore- and hyphae-biomass present from the prior colonization the decaying wood, and then (2) the enzymatic reduction of the U(VI) to U(IV) by anaerobic bacteria that use the organic components of the decaying wood as a nutrient source. Pseudomorphs of dendritic fungal hyphae, globular fungal spores, and bacterial cells composed of fine-grained uraninite or coffinite were reported.

\subsubsection{Constructed wetlands}

Constructed wetlands are widely used for the treatment of effluents from domestic and industrial sources, and from agricultural and urban storm runoff. The treatment of $U$ mine water and UMT effluent for removal of radionuclide and other contaminants by passage through constructed wetlands is used at sites including the Wismut Poehla site in Germany (Kalin et al., 2002; Küchler et al., 2006; Kunze et al., 2007), the Smolino site in Ukraine (Molchanov et al., 2004), and the Ranger mine in Australia (Ring et al., 2004). Biogeochemical removal processes for contaminants in such systems include sorption on sediments and biofilm components, and uptake by algae and higher plants. Physical and chemical treatment circuits may be added in tandem with the wetlands system, at the upstream and/or downstream ends.

An example of such a dual approach is seen at the Wismut Poehla site, where a pilot plant facility was begun in 1998 to treat effluents $(\mathrm{pH}$ 6.8-7.6) from flooded $U$ mines and seepage from UMT and waste rock piles. Aeration was used to produce a ferric hydrous oxide floc that was then removed from the slurry in an initial sludge pond and downstream settling pond whose design included floating mats made of high surface area polymers (AquaMats $\left.{ }^{\circledR}\right)$ designed to encourage biofilm production. The outflow from the settling pond then entered a sequence of wetland basins: (1) a bed with gravel plus sewage sludge and straw to supply nutrients for plant and microbial growth downstream, (2) a pond with a gravel and sand bed planted with vascular aquatic plants indigenous to the region [Typha latifolia (common cattail), Juncus inflexus (European meadow rush), Juncus effuses (common rush), Phragmites communis (common reed), and Iris pseudacorus (swamp iris)], and (3) the final treatment cell, underlain by gravel, soil, and compost and planted with the same species as the gravel + sand bed.

Küchler et al. (2006) note that it takes several growing seasons for the biota to become established and reach their full-performance capability, that strong seasonal variations are possible, and that in a worst case scenario, treatment capability may be severely impaired. After several years of operation, the Wismut pilot plant had average removal rates of $73 \%$ for Ra and $83 \%$ for As. Arsenic removal was predominantly in the sludge pond, associated with ferric hydrous oxide precipitation. In contrast, Ra removal occurs incrementally at each section of the system, reflecting a variety of biotic and abiotic retention processes. Kalin et al. (2002) suggest that diatoms present in the biofilms on the wetland substrate may play a role in Ra retention. Whereas diatom removal of soluble Ra has received little attention in freshwater systems, it has been reported in marine systems (Koide et al., 1976). Recent work by Bonny and Jones (2007) on a saline spring in Utah noted for its radioactive barite deposits showed that bioaccumulation of $\mathrm{Ba}$ in diatom tissues and adsorption of $\mathrm{Ba}$ to diatom extracellular polysaccharides can lead to precipitation of barite (and coprecipitation of Ra) in microbial mats. Such a mechanism also may be operative for Ra removal in wetlands.

When the Wismut treatment plant was scaled-up from the pilot stage in 2003, an additional feature was introduced-the use of the macrophytic alga Characeae (often referred to as Chara or stonewort, the latter term due to the calcium carbonate deposits on its tissue) in the wetland basins for enhanced Ra and As removal [see (Landa, 2004) regarding Chara and its role in ${ }^{226}$ Ra cycling at UMT ponds]. Final downstream polishing of the effluents for Ra and As removal was achieved by passage through channels filled with a granulated $\mathrm{BaSO}_{4}$ (Hedulat ${ }^{\circledR}$ ) and granulated ferric hydroxide (FerroSorp ${ }^{\circledR}$ ) (Kunze et al., 2007).

No removal of $U$ from the Wismut pilot plant was observed during the initial 3-year run (Kalin et al., 2002). This result was attributed to the likely occurrence of $\mathrm{U}$ as $\mathrm{UO}_{2}\left(\mathrm{CO}_{3}\right)_{3}^{4-}$ in the near-neutral pH effluent [bicarbonate $\sim 1 \mathrm{~g} / \mathrm{L}$ (Kunze et al., 2007)]. This lack of $U$ removal is in contrast to the $86 \% \mathrm{U}$ removals 
reported at the longer-operating Smolino, Ukraine wetland. Studies on sediments from the Ranger mine constructed wetland have shown that carbon may be limiting bacterial sulfate reduction, and that addition of acetate, compost, or algal biomass simulated sulfate reduction rates (Ring et al., 2004). Such studies suggest that biostimulation may aid in the operation of constructed wetlands, and promote bacterial $U$ reduction as well as sulfate reduction. At the Schlema-Alberoda pilot-scale constructed wetland in Germany, $U$ removal from mine waters was initiated and sustained by dosing with molasses (Gerth et al., 2006). With maturation of constructed-wetland biotic communities and accumulation of readily degraded organic detritus, enhanced bacterially mediated $\mathrm{U}$ removals hopefully can be achieved without additions of allochthonous organic matter or other nutrient amendments. It is of interest to note that at the start of the Schlema-Alberoda tests, a initial heavy loading of the system with molasses resulted in good retention of $U$ by the sediment of the treatment cells, but unacceptable mobilization of As.

\section{Sustainability}

Organizations such as the USGS have recognized that "the Nation will have to balance the land, water, and environmental effects of resource development and extraction with the benefits of use, and, perhaps most important, it will have to plan for evolving and unanticipated future energy and mineral resource requirements within this broader environmental perspective of sustainability" (USGS, 2007). Although there are a number of definitions of "sustainability," this discussion will focus on the aspects of geochemistry that relate to environmental sustainability.

\subsection{Environmental management}

The key to environmental sustainability is diligent environmental management throughout the life cycle of a U mine operation from exploration to development to remediation/closure (IAEA, 2009a). Tools such as life cycle analysis (LCA) are evolving to understand the global impact of $U$ mining. Life cycle approaches can involve identifying, quantifying and assessing materials and energy inputs to systems including energy and water inputs, emissions, effluents and wastes, and transportation requirements; tonnage, grade and lifetime of a deposit also may be significant indicators of environmental sustainability (IAEA, 2009a). A recent comparison of water and energy consumption and waste emissions data throughout the mine life cycle from U extraction operations in Australia show an increasing trend of mining deeper deposits which, in turn, will require more energy for extraction. In addition, a steady decline in most average ore grades in the US from $0.28 \%$ in the 1950 s to $0.07-0.11 \% \mathrm{U}_{3} \mathrm{O}_{8}$ in the $1990 \mathrm{~s}$ is apparent, and would mean an increased tonnage of tailings and waste rock (Mudd and Diesendorf, 2008) but likely with lower radioactivity. Additionally, energy and water consumption and greenhouse gas emissions are sensitive to ore grade (Mudd and Diesendorf, 2008). Thus, developing exploration methods for finding and characterizing larger, high-grade reserves with minimal environmental disturbance at the beginning of the life cycle would contribute to sustainability (McLemore and Turner, 2006).

Management of both tailings and water are the most significant areas where the $U$ mining industry can improve sustainability (IAEA, 2009a). For example, management could entail limiting waste generation and mitigation of transport of the trace metals from the site by adherence to the " 12 principles of Green Engineering” (Anastas and Zimmerman, 2003). An example of Green Engineering-preventing waste rather than cleaning it up after it has formed - includes the waste mitigation practices applied for the water quality protection downstream from the Ranger Uranium Project in the Alligator Rivers Region in the Northern Territory of Australia. The Ranger Uranium Project has, to date, operated under a "zero-release" water management system and has met the prevailing water quality protection requirements for $U$ (Ferguson and Mudd, 2011). The evolution of water quality guidelines at the Ranger site has occurred over time, as scientific research has expanded the knowledge of ecotoxicity of contaminants on local indicator species (Ferguson and Mudd, 2011), providing a good example of site-specific studies, rather than a "one size fits all" approach, another Green Engineering Principle (Anastas and Zimmerman, 2003).

\subsection{Lower footprint technologies}

Uranium extraction by ISR technology has been regarded as a step in the direction of sustainability in its minimization of solid wastes, smaller footprint, elimination of the need for dewatering and absence of waste rock and tailings as compared with conventional open pit and underground $U$ mining and milling (OCED, 1983; IAEA, 2009a). However, because a considerable number of issues still remain regarding lower efficiency of $U$ recovery, postmining groundwater quality, the potential for excursions of fluids from the mining zone and difficulties in achieving restoration at ISR sites, work still needs to be done toward achieving environmental sustainability and waste mitigation. Researchers have suggested the refinement of ISR methods to lessen the impact on groundwater quality by the development of alternative lixiviants during ISR. Solutions include applying stronger (e.g., EDTA or citrate) complexing agents that would leave behind less U, utilizing U-specific complexing agents (e.g., isosaccarinic and gluconic acids) that would not mobilize other potential pollutants (As, Se, $\mathrm{V}, \mathrm{Mo}$ ), or using organic lixiviants containing readily degradable complexing agents (Krumhansl et al., 2009). Furthermore, minimization of environmental impacts from ISR will require an evaluation of the entire $U$ mineral life cycle. Simply stated, mining methods and lixiviant selection will depend on the site-specific characteristics of the ore body such as ore grade, mineralogy, geology, and host-rock permeability. The mining methods influence the wastes produced. In turn, both residual wastes and the extent to which mining has been completed will influence the restoration measures required (Shuck, 1979).

\subsection{Multi-element deposits and their tailings and effluents: Environmental and economic aspects}

The processes that enrich $U$ also tend to enrich other elements with economic value (e.g., $\mathrm{Cu}, \mathrm{Ag}, \mathrm{Au}, \mathrm{Fe}, \mathrm{Sn}, \mathrm{V}, \mathrm{Mo}, \mathrm{Pb}$, and REE). However, depending on economic and mining feasibility factors, not all of these elements necessarily are recovered. By virtue of their compositional differences and extraction treatments, the exploitation of new ore types may require environmental monitoring and controls for constituents not typically considered in U mining and milling scenarios. Such is the case for the proposed Kvanefjeld U mine in southern Greenland. The geology of the area was investigated in the late 1800 s and radiometric exploration was carried out by the Danish Atomic Energy Commission (then under the leadership of Niels Bohr) in 1955. The ore body consists of alkaline syenites and nepheline syenites occurring as intrusions in granite (Pilegaard, 1990). The syenites contain the mineral villiaumite $(\mathrm{NaF})$, and some waters in the region contain $\mathrm{F}$ concentrations of $0.5-30 \mathrm{mg} / \mathrm{L}$ compared to concentrations of $0.1-0.2 \mathrm{mg} / \mathrm{L}$ typically seen in areas remote from the intrusive zone. In planning for and environmental assessments of $U$ mining and milling at this site, fluoride is regarded as the most challenging waste disposal 
issue, due to the element's abundance, mobility, and toxicity (Pilegaard, 1990).

Sodium fluoride constitutes about $1 \%$ of the ore, and is solubilized in the high pressure/high temperature carbonate leach process used to extract the $U$ (mill feed-grade ore contains about $365 \mathrm{mg} / \mathrm{kg} \mathrm{U}$ ). Thus, high concentrations of soluble $\mathrm{F}$ would be expected in the mill effluent. Calcium sulfate could be added to the waste stream to precipitate the $\mathrm{F}$ as $\mathrm{CaF}_{2}$. The addition of an excess of sulfate has been proposed in the waste treatment plan to satisfy the requirements of $(\mathrm{Ba}, \mathrm{Ra}) \mathrm{SO}_{4}$ precipitation, thus generating a mixed-phase sludge. Residual $\mathrm{F}$ in the tailings solids, perhaps present, in part, as undissolved ore particles, may represent a long-term source of $\mathrm{F}$ to the environment.

Sodium fluoride is highly soluble in water (about $40,000 \mathrm{mg} / \mathrm{L}$ at $25^{\circ} \mathrm{C}$ or $18,000 \mathrm{mg} / \mathrm{L} \mathrm{F}$, assuming stoichiometric dissolution and saturation), thus runoff from ore stockpiles also can be expected to have high $\mathrm{F}$ concentrations. Indeed, water draining a test tunnel driven in 1979-1980 showed F concentrations of $200-3000 \mathrm{mg} / \mathrm{L}$, and runoff from ore storage pads at the Riso National Laboratory in Denmark showed F concentrations of $700-1400 \mathrm{mg} / \mathrm{L}$ following heavy rains (Pilegaard, 1990) (for comparison, the current USEPA National Secondary Drinking Water Regulation for $\mathrm{F}$ is $2 \mathrm{mg} / \mathrm{L}$ ).

No mining of the Kvanefjeld deposit has occurred as of 2012. Previous studies have focused on the $U$ content of the host rock, the Ilimaussaq alkaline intrusion. The intrusion also is enriched in REE (Pilegaard, 1990). Global demand for REE is high, with applications in the production of permanent magnets for use in hybrid vehicles, cell phones, and wind turbines currently being a major driver (Kramer, 2010). If the REE content of the ore is shown to be of economic significance, then REE, as well as U recovery may be considerations in assessing the viability of the project.

The Witwatersrand Basin of South Africa is an example of a multi-element deposit that has been mined for both Au and U. Uranium occurs along with $\mathrm{Au}$ in this pyritic ore (Au:U ratios range from $1: 10$ to $1: 100$ ) and has been recovered by sulfuric acid extraction as a by-product of Au mining when $U$ prices have been favorable. At other times, $U$ has been discharged into waste impoundments along with the Au tailings, following cyanide leaching for Au recovery; thus, the radiological character of the tailings has varied with the $U$ market. Uranium recovery began in 1952 and during the period 1952-1991, approximately 170,000 metric tons of $\mathrm{U}_{3} \mathrm{O}_{8}$ were produced. At the peak of $U$ prices in 1980, 9 of 22 Au mines that were active at the time produced $U$; this production declined in the coming decades and by 2005 , only one U-recovery plant was in operation.

Uranium extraction for these ores is about $90 \%$, and thus the $U$ content of the tailings will vary approximately 10 -fold with and without U-recovery. Without U recovery, the typical Witwatersrand tailings contain $\sim 100 \mathrm{mg} / \mathrm{kg} \mathrm{U}$. This concentration is not much different than those seen in UMT derived from low grade U-ores from deposits in other regions [i.e., ores of approximately $1000 \mathrm{mg} / \mathrm{kg}$ or $0.1 \% \mathrm{U}]$. Whereas such total concentrations establish the magnitude of the inventory, the leachability of the radionuclides in the tailings is of greater importance in assessing environmental mobility and potential bioavailability. No studies on the effect of cyanidation on the chemical form of ${ }^{238} \mathrm{U}$ and its decay products appear to have been published. Work along these lines would appear to be a future research priority; of note are recent investigations by Kyle (2012) on the fate of selected trace elements ( $\mathrm{Pb}, \mathrm{Cd}, \mathrm{Hg}, \mathrm{As}, \mathrm{Sb}, \mathrm{Se}$, and $\mathrm{Te}$ ) during the cyanidation process for gold recovery.

Uranium concentrations in the process waters from Au-only extraction plants are commonly not high [i.e., most of the $U$ is left in the leached ore and dumped along with the tailings] (F. Winde, written communication, 17 May 2010). The Au tailings impoundments are thus potential sources of contamination by $\mathrm{U}$ and its decay products. Winde and van der Walt (2004) have studied the seepage from the tailings impoundment at the Buffelsfontein Au mine in South Africa. Salinization of floodplain soils and the non-perennial stream (the Koekemoer Spruit; the Afrikaans word "spruit" meaning a creek or small stream) draining the site has been noted. Salt crusts with $U$ concentrations as high as $1200 \mathrm{mg} / \mathrm{kg}$ are formed by the capillary rise of shallow groundwater and its evaporation at the soil/air interface. The groundwater also is high in dissolved Fe and $\mathrm{Mn}$. On reaching the aerated hyporheic zone of the streambed, Fe and Mn precipitate as $\mathrm{Fe} / \mathrm{Mn}$ hydrous oxides that have the potential to sorb radionuclides and trace element contaminants and limit downstream transport. Indeed there is a strong correlation between the $U$ concentration of streambed sediments and their Fe $(r=0.97)$ and $\mathrm{Mn}(r=0.91)$ contents. Changes in stream water chemistry, or burial and diagenetic changes (including microbial reduction of Fe and Mn precipitates), could lead to subsequent release of contaminants to contacting waters.

Flow in these small streams is sustained by $\mathrm{CO}_{2}$-rich groundwater pumped from the mines. Diurnal shifts in $\mathrm{pH}$ of stream waters that influence the surface-charge characteristics of these precipitates may play a role in retention of these contaminants in the streambed sediments of this system. Additionally, these diurnal shifts may influence calcium carbonate precipitation and its coprecipitation of dissolved U. For these reasons, diurnal patterns should be considered in the scheduling of water quality sampling events (Winde and van der Walt, 2004; Winde et al., 2004). The Koekemoer Spruit flows across a karst terrain and losses of flow to sinkholes are common. In other parts of the Witwatersrand Basin, sinkholes resulting from mine dewatering have been filled with Au mine tailings (Swart et al., 2003). These situations create the potential for direct and long-term contamination of the underlying dolomitic aquifer.

\subsection{Natural attenuation}

The success of restoration and final closure ultimately may depend on the ability to return the aquifer to conditions that originally caused the deposit to form through natural processes (i.e., natural attenuation). From a geochemical perspective, natural attenuation may be an opportunity for selecting ISR U mine sites based on the ability of the natural environment to sequester $U$ and other trace contaminants remaining in solution following mining. For example, if the reductant initially responsible for the precipitation of uraninite in the deposit [e.g., pyrite, marcasite, organic carbon, $\mathrm{H}_{2} \mathrm{~S}_{(\mathrm{g})}$, and sometimes reduced $\mathrm{U}(\mathrm{IV})$ minerals] is persistent in the downgradient aquifer materials, there may be sufficient reducing capacity remaining to promote the spontaneous removal of redox-sensitive elements by the formation of reduced solid species such as uraninite (Osiensky and Williams, 1990; Deutsch et al., 1984). If the U-mining zone is amenable to restoration by reductive precipitation, the "reducing capacity" measurement may be an indicator of natural attenuation potential, especially when the lixiviant composition is compatible with the original groundwater (Osiensky and Williams, 1990). The reducing capacity of an aquifer would provide an indication of capacity to consume the excess oxidant used in ISR. Although measuring the reducing capacity of aquifers is not straightforward and is an active area of research, Barcelona and Holm (1991) found that within a sand-and-gravel aquifer, the groundwater contributed less than $1 \%$ of the system reducing capacity and aquifer solids provided most of the reduction poising capacity. A study of a south Texas orebody also reported the reducing capacity as the amount of reduced species present (such as pyrite) and generally reflected the oxidation state of the Fe (Paul and Venuto, 1982). Reducing capacity in a coffinite 
ore from the Jurassic Morrision Formation (around Crownpoint, New Mexico) was estimated at $0.61 \mathrm{meq} / \mathrm{g}$, mainly due to the presence of pyrite. It is expected to be much higher (up to $3 \mathrm{meq} / \mathrm{g}$ ) when pyrite is present in higher concentrations (Vogt et al., 1982a), although other reduced Fe, S and Mn minerals and organic matter could contribute to reducing capacity (Barcelona and Holm, 1991). Reduction reactivity also could be potentially controlled by microbial activity and pH (Hartog et al., 2002). Additionally, natural processes such as mineral precipitation and adsorption could provide sequestration of trace metal contaminants at ISR sites (Deutsch et al., 1985).

\subsection{Selecting sites with potential for lower environmental impact}

In addition to improved recovery techniques and proper remediation of $U$ mine or mill sites to achieve a safe and environmentally acceptable condition, sustainability of the U mining industry also depends on continued exploration and development of new ore bodies as older ones are depleted (IAEA, 2009a). Perhaps sustainability also can be incorporated into the exploration side of the $U$ mine life cycle by focusing on the search for and development of $U$ deposits on properties which are environmentally, economically and socially responsible (McLemore and Turner, 2006). For example, sustainability in U extraction and resource development may focus on $U$ ore bodies and mining processes that will result in decreased footprint and environmental impact. This approach will have both economic and environmental advantages over those that are likely to result in large releases of contaminants to surrounding air, land or water (NAS, 2002). Geochemical investigations can play an important role in the development of metrics needed to compare tradeoffs of $U$ resource development and to better understand the potential environmental effects. Some geochemical indicators of potential for environmental impact could include (NAS, 2002):

- groundwater and surface water quality before and after mining,

- trace elements in existing soils to understand changes in background concentrations that may occur upon mining or milling, as well as the potential for the environment to sequester or naturally attenuate trace metal contaminants released during mining,

- trace elements in ores, particularly elements of concern commonly associated with U ore bodies,

- the potential for acid-rock drainage (amounts of sulfide minerals and buffering minerals, climate, and hydrology, etc.)

These geochemical indicators can be coupled with knowledge of the existence and location of sensitive biological communities, location of aquifers in relation to ore bodies, climatological impacts on mining operations (e.g., precipitation and prevailing winds), and socioeconomic and cultural issues to identify opportunities for sustainable development. These indicators may be integrated into future $U$ resource assessments to help understand how the occurrence, formation processes, and extraction methods, as well as how the waste products of $U$ resources influence landscape, water, ecosystems, and human health (USGS, 2007).

Tools such as a qualitative, conceptual geoenvironmental model (du Bray, 1995), can facilitate identification of potential geochemical indicators of contamination and sequestration agents related to a given deposit type. In this context, geoenvironmental models include a "compilation of geologic, geochemical, geophysical, hydrologic, and engineering information pertaining to the environmental behavior of geologically similar deposits prior to mining and resulting from mining, mineral processing and smelting" (Seal et al., 1995). Information found in a geoenvironmental model used in conjunction with knowledge regarding mineralogy mineral chemistry, hydrology, climate and transport processes can help to establish linkages among the geologic attributes of a deposit, its environmental setting and its historical and future mining techniques and environmental behavior. Such applications can be used to inform potential for contamination, waste generation, and/or environmental restoration, as well as provide insight that can be useful in mine planning, mineral exploration, permitting of proposed mines, and mine reclamation plans (Plumlee and Nash, 1995). For example, a geoenvironmental model for the world's largest breccia pipe-hosted U province in Northern Arizona identified the potential for acid drainage containing toxic metal(loid)s (such as Ag, As, Ba, Cd, Co, Cr, Cu, Hg, Mo, Ni, Pb, Sb, Se, Sr, U, V, $\mathrm{Y}$, and $\mathrm{Zn}$ ) in the immediate vicinity of mineralized pipes where they are dissected and exposed to flooding and catastrophic precipitation. However, it was noted that the limestone and calcareous sandstone host rocks likely would buffer acidic runoff water and downward percolating water efficiently prior to or during their transport in aquifer systems (Wenrich et al., 1995). Additionally, because very little water moves downward into the pipes, and because (1) ore bodies in this deposit are located, on average, $300 \mathrm{~m}$ below the surface, and (2) water bodies within $600 \mathrm{~m}$ of the plateau surface are rare, long-distance transport of these elements was predicted to be slight (Wenrich et al., 1995). A 2009 environmental assessment of the effects of 1980s mining in the Kanab Creek, Arizona area found that trace element concentrations in water samples that were thought to be associated with $U$ mining (2-20 $\mu \mathrm{g} \mathrm{U} / \mathrm{L})$ were not significantly elevated above those waters found in non-impacted areas $(0.06-21 \mu \mathrm{g} / \mathrm{L})$, although the data are considered preliminary (Bills et al., 2010). Likewise, concentrations of trace metals in surface soils and stream sediments from the former Hermit Mine, which was located on a flat area not susceptible to flooding averaged $4.6 \mathrm{mg} / \mathrm{kg} \mathrm{U}$ within the reclaimed area and dropped to regional background levels of $1.7 \mathrm{mg} / \mathrm{kg} \mathrm{U}$ within $30 \mathrm{~m}$ of the reclaimed area boundary. On the other hand, the former Hack 1 Mine site, situated adjacent to the stream channel that runs through Hack Canyon, exhibited evidence of dispersion of waste rock and stream sediments containing elevated concentrations of metals, apparently the result of historical flood events (Otton et al., 2010). This variation in surficial U suggests that risk of waste release and environmental impacts from U mining may not be uniform for entire regions or deposit types, but may be due to a number of site specific attributes such as proximity to water sources, susceptibility to wind and water erosion, mining and restoration methods, elevation, and topography, to name a few. This result provides impetus to begin to examine $U$ resources in a context of the entire life cycle including the changes that the $U$ deposit may undergo during extraction, restoration, and stabilization.

Sustainability in $U$ extraction is no small task. Scientists and engineers realize that it can only be achieved when appropriate technologies are implemented in industry and disseminated throughout society (Anastas, 2003). As such, the future of sustainability will depend on the cooperation and collaboration of scientists, engineers, and stakeholders.

\section{Acknowledgements}

The authors thank Henry A. Schnell (AREVA, Paris) and Jody Waugh (Environmental Sciences Laboratory, S.M. Stoller Corporation, Grand Junction, CO) for generously providing information for this paper, Marty Goldhaber for his insights into sulfur species, and invaluable comments provided by Rich Wanty, Bob Seal, Denise Levitan, and D. Kirk Nordstrom. Funding for this work was provided by the USGS National Research Program and the Energy, Minerals, and Environmental Health Mission Area. Any 
use of trade, product, or firm names is for descriptive purposes only and does not imply endorsement by the U.S. Government.

\section{References}

Abdelouas, A., Lu, Y., Lutze, W., Nuttall, H.E., 1998a. Reduction of U(VI) to U(IV) by indigenous bacteria in contaminated ground water. J. Contam. Hydrol. 35, $217-$ 233.

Abdelouas, A., Lutze, W., Nuttall, E., 1998b. Chemical durability of uraninite precipitated on Navajo Sandstone. Comptes-rendus de l'Académie des sciences. Série 2. Fascicule A, Sciences de la terre et des planets 327, 101-106.

Abdelouas, A., Lutze, W., Nuttall, H.E., 1999. Oxidative dissolution of uraninite precipitated on Navajo Sandstone. J. Contam. Hydrol. 36, 353-375.

Abdelouas, A., 2006. Uranium mill tailings: geochemistry, mineralogy, and environmental impact. Elements 2, 335-341.

Anastas, P.T., 2003. Green engineering and sustainability. Environ. Sci. Technol. 37, 423A.

Anastas, P.T., Zimmerman, J.B., 2003. Design through the 12 principles of green engineering. Environ. Sci. Technol. 37, 94A-101A.

Anastasi, F.S., Williams, R.E., 1985. Discussion on aquifer restoration at uranium in situ leach sites. Int. J. Mine Water 4, 55-56.

Anderson, R.F., 1987. Redox behavior of uranium in an anoxic marine basin. Uranium 3, 145-164.

Anderson, R.T. et al., 2003. Stimulating the in situ activity of Geobacter species to remove uranium from the groundwater of a uranium-contaminated aquifer Appl. Environ. Microbiol. 69, 5884-5891.

ANZECC and ARMCANZ, 2000, Australian and New Zealand Guidelines for Fresh and Marine Water Quality, Canberra. <http://www.mincos.gov.au/_data/assets/ pdf_file/0014/316121/contents.pdf> (accessed 29.10.12).

Arey, J.S., Seaman, J.C., Bertsch, P.M., 1999. Immobilization of uranium in contaminated sediments by hydroxyapatite addition. Environ. Sci. Technol. 33, 337-342.

ASTDR (Agency for Toxic Substances and Disease Registry), 2009, Health Consultation, Homestake Mining Company Mill Site: Milan, Cibola County, New Mexico., Atlanta, Georgia, p. 26. <http://www.atsdr.cdc.gov/HAC/pha/ homestake/homestakeMCojun091.pdf> (accessed 05.12.12).

Barcelona, M.J., Holm, T.R., 1991. Oxidation-reduction capacities of aquifer solids. Environ. Sci. Technol. 25, 1565-1572.

Bargar, J.R., Bernier-Latmani, R., Giammar, D.E., Tebo, B.M., 2008. Biogenic uraninite nanoparticles and their importance for uranium remediation. Elements $4,407-$ 412.

Bargar, J.R., Bernier-Latmani, R., Giammar, D.E., Mehta, A., Schofield, E., Sharp, J.O., Suvorova, E.I., Ulrich, K.U., Veeramani, H., 2009. Structure, composition, size and reactivity of biogenic nano-uraninite. Geochim. Cosmochim. Acta 73, A87.

Bargar, J.R., Williams, K.H., Campbell, K.M., Long, P.E., Stubbs, J.E., Suvorova, E.L., Lezama-Pacheco, J.S., Alessi, D.S., Stylo, M., Webb, S.M., Davis, J.A., Giannar, D.E. Blue, L.Y., Bernier-Latmani, R., 2013. Uranium redox pathways in acetateamended sediments. Proc. Natl. Acad. Sci. U.S.A 110, 4506-4511.

Behrends, T., Van Cappellen, P., 2005. Competition between enzymatic and abiotic reduction of uranium(VI) under iron reducing conditions. Chem. Geol. 220 $315-327$.

Beller, H.R., 2005. Anaerobic, Nitrate-dependent oxidation of U(IV) oxide minerals by the chemolithoautotrophic bacterium Thiobacillus denitrificans. Appl Environ. Microbiol. 71, 2170-2174.

Benson, C.H., Waugh, W.J., Albright, W.H., Smith, G.M., Bush, R.P., 2011. Design and Installation of a Disposal Cell Cover Renovation Field Test: Paper Presented at WM2011 Conference, Phoenix, AZ.

Bernier-Latmani, R., Veeramani, H., Vecchia, E.D., Junier, P., Lezama-Pacheco, J.S., Suvorova, E., Sharp, J.O., Wigginton, N.S., Bargar, J.R., 2010. Non-Uraninite products of microbial U(VI) reduction. Environ. Sci. Technol. 44, 5104-5111.

Bills, D.J., Tillman, F.D., Anning, D.W., Antweiler, R.C., Kraemer, T.F., 2010. Historica and 2009 Water Chemistry of Wells, Perennial and Intermittent Streams, and Springs in Northern Arizona: USGS Scientific Investigations Report 2010-5025. Geological Survey, Reston, VA, U.S., 353 p.

Boland, D.D., Collins, R.N., Payne, T.E., Waite, T.D., 2011. Effect of amorphous Fe(III) oxide transformation on the Fe(II)-mediated reduction of $\mathrm{U}(\mathrm{VI})$. Environ. Sci. Technol. 45, 1327-1333.

Bonny, S.M., Jones, B., 2007. Diatom-mediated barite precipitation in microbial mats calcifying at Stinking Springs, a warm sulphur spring system in northwestern Utah, USA. Sed. Geol. 194, 223-244.

Borch, T., Roche, N., Johnson, T.E., 2012. Determination of contaminant levels and remediation efficacy in groundwater at a form in situ recovery uranium mine. J. Environ. Monit. 14, 1814-1823.

Boyanov, M.I., O'Loughlin, E.J., Roden, E.E., Fein, J.B., Kemner, K.M., 2007. Adsorption of $\mathrm{Fe}(\mathrm{II})$ and $\mathrm{U}(\mathrm{VI})$ to carboxyl-functionalized microspheres: the influence of speciation on uranyl reduction studied by titration and EXAFS. Geochim. Cosmochim. Acta 71, 1898-1912.

Boyanov, M.I., Fletcher, K.E., Kwon, M.J., Rui, X., O’Loughlin, E.J., Löffler, F.E., Kemner K.M., 2011. Solution and microbial controls on the formation of reduced U(IV) species. Environ. Sci. Technol. 45, 8336-8344.

Brierley, J.A., 2008. A perspective on developments in biohydrometallurgy. Hydrometallurgy 94, 2-7.

Brooks, S.C., Fredrickson, J.K., Carroll, S.L., Kennedy, D.W., Zachara, J.M., Plymale, A.E., Kelly, S.D., Kemner, K.M., Fendorf, S., 2003. Inhibition of bacterial U(VI) reduction by calcium. Environ. Sci. Technol. 37, 1850-1858.
Buchanan, R.E., Gibbons, N.E., 1974. Bergey’s Manual of Determinative Bacteriology, 8th ed. Williams \& Wilkins, Baltimore.

Burghardt, D., Kassahun, A., 2005. Development of a reactive zone technology for simultaneous in situ immobilisation of radium and uranium. Environ. Geol. 49, 314-320.

Burgos, W.D., Royer, R.A., Fang, Y., Yeh, G.T., Fisher, A.S., Jeon, B.H., Dempsey, B.A., 2002. Theoretical and experimental considerations related to reaction-based modeling: a case study using iron(III) oxide bioreduction. Geomicrobiol J. 19, 253-287.

Burgos, W.D., Senko, J.M., Dempsey, B.A., Roden, E.E., Stone, J.J., Kemner, K.M., Kelly, S.D., 2007. Soil humic acid decreases biological uranium(VI) reduction by Shewanella putrefaciens CN32. Environ. Eng. Sci. 24, 755-761.

Burgos, W.D., McDonough, J.T., Senko, J.M., Zhang, G., Dohnalkova, A.C., Kelly, S.D., Gorby, Y., Kemner, K.M., 2008. Characterization of uraninite nanoparticles produced by Shewanella oneidensis MR-1. Geochim. Cosmochim. Acta 72, 49014915.

Cabezas, J., Gamboa, Y., Clapp, L., Grant, R., McCoig, D., Bartels, C., 2010. Pilot-scale biorestoration of groundwater at a uranium ISR site by $\mathrm{H}_{2}$ injection: Paper Presented at 2010 Groundwater Summit and Groundwater Protection Council, Spring Meeting, Denver, CO.

Campbell, K.M., Kukkadapu, R.K., Qafoku, N.P., Peacock, A., Lesher, E., Williams, K.H., Bargar, J.R., Wilkins, M.J., Figueroa, L., Ranville, J., Davis, J.A., Long, P.E., 2011a. Geochemical, mineralogical, and microbiological characteristics of sediment from a naturally reduced zone in a uranium-contaminated aquifer. Appl. Geochem. 27, 1499-1511.

Campbell, K.M., Veeramani, H., Ulrich, K.U., Blue, L.Y. Giammar, D.E., BernierLatmani, R., Stubbs, J.E., Suvorova, E., Yabusaki, S., Mehta, A., Long, P.E., Bargar, J., 2011b. Oxidative dissolution of biogenic uraninite in groundwater at Old Rifle, CO. Environ. Sci. Technol. 45, 8748-8754.

Carvalho, F.P., Madruga, M.J., Reis, M.C., Alves, J.G., Oliveira, J.M., Gouveia, J., Silva, L. 2007. Radioactivity in the environment around past radium and uranium mining sites of Portugal. J. Environ. Radioact. 96, 39-46.

Carvalho, F.P., Oliveira, J.M., Faria, I., 2009a. Alpha emitting radionuclides in drainage from Quinta Do Bispo and Cunha Baixa uranium mines (Portugal) and associated radiotoxicological risk. Bull. Environ. Contam. Toxicol. 83, 668673.

Carvalho, F.P., Oliveira, J.M., Neves, M.O., Abreu, M.M., Vicente, E.M., 2009b. Soil to plant (Solanum tuberosum L.) radionuclide transfer in the vicinity of an old uranium mine. Geochem.: Explor. Environ., Anal. 9, 275-278.

Catchpole, G., Garling, R., Neumann, M., 1984. Groundwater Restoration at Wyoming Uranium Solution Mining Sites: The Mining Claim, March 1984 issue, p. 14-19. <http://www.wma-minelife.com/uranium/papers/ paperfrm.htm> (accessed 20.04.11).

Chakraborty, S., Favre, F., Banerjee, D., Mullet, M., Ehrhardt, J., Brendle, J., Vidal, L. Charlet, L., 2010. U(VI) sorption and reduction by $\mathrm{Fe}(\mathrm{II})$ sorbed on Montmorillonite. Environ. Sci. Technol. 44, 3779-3785.

Charlet, L., Silvester, E., Liger, E., 1998. N-compound reduction and actinide immobilisation in surficial fluids by $\mathrm{Fe}(\mathrm{II})$ : The surface $\equiv \mathrm{Fe}^{\mathrm{III}} \mathrm{OFe}^{\mathrm{II}} \mathrm{OH}^{0}$ species, as major reductant. Chem. Geol. 151, 85-93.

Cerrato, J.M., Barrows, C.J., Blue, L.Y., Lezama-Pacheco, J.S., Bargar, J.R., Giammar, D.E., 2012. Effect of $\mathrm{Ca}^{2+}$ and $\mathrm{Zn}^{2+}$ on $\mathrm{UO}_{2}$ dissolution. Environ. Sci. Technol. 46, 2731-2737.

Cerrato, J.M., Ashner, M.N., Alessi, D.S., Lezama-Pacheco, J.S., Bernier-Latmani, R., Bargar, J.R., Giammar, D.E., 2013. Relative reactivity of biogenic and chemogenic uraninite and biogenic noncrystalline U(IV). Environ. Sci. Technol. 47, 97569763.

Chen, B., Roos, P., Zhu, Y.G., Jakobsen, I., 2008. Arbuscular mycorrhizas contribute to phytostabilization of uranium in uranium mining tailings. J. Environ. Radioact. 99, 801-810.

Cologgi, D.L., Lampa-Pastirk, S., Speers, A.M., Kelly, S.D., Reguera, G., 2011. Extracellular reduction of uranium via Geobacter conductive pili as a protective cellular mechanism. Proc. Natl. Acad. Sci. U.S.A 108, 15248-15252.

Dahlkamp, F.J., 1993. Uranium Ore Deposits. Springer-Verlag, Berlin.

Darling, B.K., 2008. Report on Findings Related to the Restoration of Groundwater at In situ Uranium Mines in South Texas: Southwest Groundwater Consulting, LLC, Austin, TX, 46 p. <http://www.uraniuminfo.org/files/BK_Darling\%20Report_ Complete_Sept_30.pdf > (accessed 05.12.12).

Davis, J.A., Curtis, G.P., 2007. Consideration of Geochemical Issues in Groundwater Restoration at Uranium in situ Leach Mining Facilities: NUREG/CR-6870. U.S Nuclear Regulatory Commission, Washington, DC, 86 p.

deLemos, J.L., Bostick, B.C., Quicksall, A.N., Landis, J.D., George, C.C., Slagowski, N.L., Rock, T., Brugge, D. Lewis, J., Durant, J.L., 2008. Rapid dissolution of soluble uranyl phases in arid, mine-impacted catchments near Church Rock, NM. Environ. Sci. Technol. 42, 3951-3957.

Descostes, M., Schlegel, M.L., Eglizaud, N., Descamps, F., Miserque, F. Simoni, E. 2010. Uptake of uranium and trace elements in pyrite $\left(\mathrm{FeS}_{2}\right)$ suspensions. Geochim. Cosmochim. Acta 74, 1551-1562.

Deutsch, W.J., Eary, L.E., Marin, W.J., McLaurine, S.B., 1984. Use of Sodium Sulfide to Restore Aquifers Subjected to in situ Leaching of Uranium Ore Deposits: PNLSA-12685, CONF-850151-2. Pacific Northwest Labs, Richland, WA, 26 p.

Deutsch, W.J., Martin, W.J., Eary, L.E., Serne, R.J., 1985. Methods of Minimizing Ground-water Contamination from in situ Leach Uranium Mining, Final Report: NUREG/CR-3709, PNL-5319. U.S. Nuclear Regulatory Commission, Washington, DC, $157 \mathrm{p}$.

DiSpirito, A.A., Tuovinen, O.H., 1989. Uranous ion oxidation and carbon dioxide fixation by Thiobacillus ferrooxidans. Arch. Microbiol. 133, 28-32. 
Dodge, C.J., Francis, A.J., Gillow, J.B., Halada, G.P., Eng, C., Clayton, C.R., 2002. Association of uranium with iron oxides typically formed on corroding steel surfaces. Environ. Sci. Technol. 36, 3504-3511.

Dong, W., Brooks, S.C., 2006. Determination of the formation constants of ternary complexes of uranyl and carbonate with alkaline earth metals $\left(\mathrm{Mg}^{2+}, \mathrm{Ca}^{2+}, \mathrm{Sr}^{2+}\right.$ and $\mathrm{Ba}^{2+}$ ) using anion exchange method. Environ. Sci. Technol. 40, 4689-4695.

du Bray, E.A., 1995. Preliminary Compilation of Descriptive Geoenvironmental Mineral Deposit Models: USGS Open File Report 95-831. USGS, Denver, 272 p.

Duff, M.C., Coughlin, J.U., Hunter, D.B., 2002. Uranium co-precipitation with iron oxide minerals. Geochim. Cosmochim. Acta 66, 3533-3547.

Eglizaud, N., Miserque, F., Simoni, E., Schlegel, M., Descostes, M., 2006. Uranium(VI) interaction with pyrite $\left(\mathrm{FeS}_{2}\right)$ : chemical and spectroscopic studies. Radiochim. Acta 94, 651-656.

Ehrlich, H.L., 2001. Past, present and future of biohydrometallurgy. Hydrometallurgy 59, 127-134.

Evseeva, T., Majstrenko, T., Geras'kin, S., Brown, J.E., Belykh, E., 2009. Estimation of ionizing radiation impact on natural Vicia cracca populations inhabiting areas contaminated with uranium mill tailings and radium production wastes. Sci. Total Environ. 407, 5335-5343.

Fairchild, J.F., Allert, A.L., Poulton, B.C., Graham, R.V., 2002. A site-specific assessment for the impacts of ammonia on Colorado pike minnow and razorback sucker populations in the upper Colorado River, adjacent to the Atlas mill tailings pile, Utah. Final Report to the U.S. Fish and Wildlife Service, Off-Refuge Contaminant Assessment Program: USGS, Salt Lake City, UT. <http:// www.cerc.usgs.gov/pubs/center/pdfDocs/Colorado_River.pdf> (accessed 15.10.12).

Fairchild, J.F., Allert, A.L., Sappington, L.C., Waddell, B., 2005. Chronic toxicity of unionized ammonia to early life-stages of endangered Colorado pikeminnow (Ptychocheilus lucius) and razorback sucker (Xyrauchen texanus) compared to the surrogate fathead minnow (Pimephales promelas). Arch. Environ. Contam. Toxicol. 49, 378-384.

Fang, Y., Yabusaki, S.B., Morrison, S.J., Amonette, J.P., Long, P.E., 2009. Multicomponent reactive transport modeling of uranium bioremediation field experiments. Geochim. Cosmochim. Acta 73, 6029-6051.

Fedorak, P.M., Westlake, D.W.S., Anders, C., 1986. Microbial release of ${ }^{226} \mathrm{Ra}^{2+}$ from (Ba, Ra) $\mathrm{SO}_{4}$ sludges from uranium mine wastes. Appl. Environ. Microbiol. 52, 262-268.

Ferguson, B., Mudd, G.M., 2011. Water Quality, Water management and the Ranger uranium project: guidelines, trends and issues. Water Air Soil Pollut. 217, $347-$ 363.

Finch, R., Murakami, T., 1999. Systematics and paragenesis of uranium minerals: Uranium. In: Burns, P.C., Finch, R. (Eds.), Mineralogy, Geochemistry, and the Environment, vol. 38. Mineralogical Society of America, Washington D.C, pp. 91-179.

Finch, R.J., Ewing, R.C., 1992. The corrosion of uraninite under oxidizing conditions. J. Nucl. Mater. 190, 133-156.

Finch, W.I., Butler, A.P., Armstrong, F.C., Weissenborn, A.E., 1972. Nuclear Fuels: Uranium: USGS Professional Paper 820, Washington, D.C., pp. 456-467.

Finneran, K.T., Housewright, M.E., Lovley, D.R., 2002. Multiple influences of nitrate on uranium solubility during bioremediation of uranium-contaminated subsurface sediments. Environ. Microbiol. 4, 510-516.

Fletcher, K.E., Boyanov, M.I., Thomas, S.H., Wu, Q., Kemner, K.M., Löffler, F.E., 2010. $\mathrm{U}(\mathrm{VI})$ reduction to mononuclear U(IV) by Desulfitobacterium species. Environ. Sci. Technol. 44, 4705-4709.

Fredrickson, J.K., Zachara, J.M., Kennedy, D.W., Duff, M.C., Gorby, Y.A., Li, S.M.W., Krupka, K.M., 2000. Reduction of U(VI) in goethite ( $\alpha-\mathrm{FeOOH}$ ) suspensions by a dissimilatory metal-reducing bacterium. Geochim. Cosmochim. Acta 64, 30853098.

Fredrickson, J.K., Zachara, J.M., Kennedy, D.W., Liu, C., Duff, M.C., Hunter, D.B., Dohnalkova, A., 2002. Influence of Mn oxides on the reduction of uranium(VI) by the metal-reducing bacterium Shewanella putrefaciens. Geochim. Cosmochim. Acta 66, 3247-3262.

Fuller, C.C., Bargar, J.R., Davis, J.A., Piana, M.J., 2002. Mechanisms of uranium interactions with hydroxyapatite: implications for groundwater remediation. Environ. Sci. Technol. 36, 158-165.

Fuller, C.C., Bargar, J.R., Davis, J.A., 2003. Molecular-scale characterization of uranium sorption by bone apatite materials for a permeable reactive barrier demonstration. Environ. Sci. Technol. 37, 4642-4649.

Gallegos, T.J., Fuller, C.C., Webb, S.M., Betterton, W., 2013. Uranium(VI) interactions with mackinawite in the presence and absence of bicarbonate and oxygen. Environ. Sci. Technol. 47, 7357-7364.

Ganesh, R., Robinson, K., Reed, G., Sayler, G., 1997. Reduction of hexavalent uranium from organic complexes by sulfate- and iron-reducing bacteria. Appl. Environ. Microbiol. 63, 4385-4391.

Gao, Y., Baeyens, W., De Galan, S., Poffijn, A., Leermakers, M., 2010. Mobility of radium and trace metals in sediments of the Winterbeek: application of sequential extraction and DGT techniques. Environ. Pollut. 158, 2439-2445.

Geissler, A., Selenska-Pobell, S., 2005. Addition of U(VI) to a uranium mining waste sample and resulting changes in the indigenous bacterial community. Geobiology 3, 275-285.

Geißler, A., 2007. Prokaryotic Microorganisms in Uranium Mining Waste Piles and their Interactions with Uranium and Other Heavy Metals. Technical University of Freiberg, Ph.D. thesis. <http://d-nb.info/988321181/34> (accessed 06.12.12).

Gerth, A., Hebner, A., Kiessig-Zellmer, A., 2006. Passive treatment of minewater at the Schlema-Alberoda site. In: Merkel, B.J., Hasche-Berger, A. (Eds.), Uranium in the Environment: Mining Impacts and Consequences. Springer, Berlin, pp. 409414.

Ginder-Vogel, M., Criddle, C.S., Fendorf, S., 2006. Thermodynamic constraints on the oxidation of biogenic $\mathrm{UO}_{2}$ by $\mathrm{Fe}(\mathrm{III})$ (hydr)oxides. Environ. Sci. Technol. 40 3544-3550.

Ginder-Vogel, M., Stewart, B., Fendorf, S., 2010. Kinetic and mechanistic constraints on the oxidation of biogenic uraninite by ferrihydrite. Environ. Sci. Technol. 44, 163-169.

Goldhaber, M.B., Reynolds, R.L., Rye, R.O., 1978. Origin of a south Texas roll-type uranium deposit: II. Sulfide petrology and sulfur isotope studies. Econ. Geol. 73 1690-1705.

Gorby, Y.A., Lovley, D.R., 1992. Enzymatic uranium precipitation. Environ. Sci. Technol. 26, 205-207.

Granger, H.C., Warren, C.G., 1969. Unstable sulfur compounds and the origin of rolltype uranium deposits. Econ. Geol. 64, 160-171.

Granger, H.C., Warren, C.G., 1974. Zoning in the Altered Tongue Associated with Roll-Type Uranium Deposits. International Atomic Energy Agency, Vienna, pp. 185-199.

Grant, D.C. 1980. In situ leaching studies of uranium ores: phase V Contract H0262004, Westinghouse Electric Corp., Research and Development. US Bureau of Mines OFR-84-81/PB-81-222739. US Bureau of Mines, Washington, DC.

Grant, D.C., Seidel, D.C., Nichols, I.L., 1985. Technique for in situ leach simulation of uranium ores (Contract $\mathrm{H0262004}$, Westinghouse Electric Corp, Research and Development): Bureau of Mines OFR 192-84/PB-85-145902/AS. US Bureau of Mines, Washington, DC, 61 p.

Großmann, K, Arnold, T, Krawczyk-Bärsch, E, Diessner, S, Wobus, A , Bernhard, G Krawietz, R., 2007. Identification of fluorescent $\mathrm{U}(\mathrm{V})$ and $\mathrm{U}(\mathrm{VI})$ microparticles in a multispecies biofilm by confocal laser scanning microscopy and fluorescence spectroscopy. Environ. Sci. Technol. 41, 6498-6504.

Gu, B., Liang, L., Dickey, M.J., Yin, X., Dai, S., 1998. Reductive precipitation of uranium(VI) by zero-valent iron. Environ. Sci. Technol. 32, 3366-3373.

Gu, B., Chen, J., 2003. Enhanced microbial reduction of $\mathrm{Cr}(\mathrm{VI})$ and $\mathrm{U}(\mathrm{VI})$ by different natural organic matter fractions. Geochim. Cosmochim. Acta 67, 3575-3582.

Gu, B., Yan, H., Zhou, P., Watson, D.B., Park, M., Istok, J., 2005. Natural humics impact uranium bioreduction and oxidation. Environ. Sci. Technol. 39, 5268-5275.

Guillamont, R.R.T., Neck, V., Fuger, J., Palmer, D., Grenthe, I., Rand, M., 2003. Update on the Chemical Thermodynamics of Uranium, Neptunium, Plutonium, Americium and Technetium. Elsevier, Amsterdam, 919 p.

Gustafsson, J.P., 2010, Visual Minteq. <http://www2.lwr.kth.se/English/ OurSoftware/vminteq/> (accessed 05.12.12)

Hall, S., 2009. Groundwater Restoratoin at Uranium in situ Recovery Mines, South Texas Coastal Plain: Open-file Report 2009-1143. US Geological Survey, Reston, VA, 32 p.

Hartog, N., Griffioen, J., Van der Weijden, C.H., 2002. Distribution and reactivity of $\mathrm{O}_{2}$-reducing components in sediments from a layered aquifer. Environ. Sci. Technol. 36, 2338-2344.

Ho, C.K., Arnold, B.W., Cochran, J.R., Taira, R.Y., 2002. Development of a risk-based probabilistic performance assessment method for long term cover systems, SAND2002-3131 2nd ed. Sandia National Laboratories, Albuquerque, New Mexico.

Hofmann, B.A., 1989. Geochemical analogue study in the Krunkelbach Mine, Mezenschwand, southern Germany: geology and water-rock interactions. Sci. Basis Nuclear Waste Manag. XII, Mater. Res. Soc. Symp. Proc. 127, 921-926.

Hsi, C.D., Langmuir, D., 1985. Adsorption of uranyl onto ferric oxyhydroxides: application of the surface complexation site-binding model. Geochim. Cosmochim. Acta 49, 1931-1941.

Hua, B., Xu, H.F., Terry, J., Deng, B.L., 2006. Kinetics of uranium(VI) reduction by hydrogen sulfide in anoxic aqueous systems. Environ. Sci. Technol. 40, 46664671.

Hua, B., Deng, B., 2008. Reductive immobilization of uranium(VI) by amorphous iron sulfide. Environ. Sci. Technol. 42, 8703-8708.

Huang, J.W., Blaylock, M.J., Kapulnik, Y., Ensley, B.D., 1998. Phytoremediation of uranium-contaminated soils: role of organic acids in triggering uranium hyperaccumulation in plants. Environ. Sci. Technol. 32, 2004-2008.

Hyun, S.P., Davis, J.A., Sun, K., Hayes, K.F., 2012. Uranium(VI) reduction by iron(II) monosulfide mackinawite. Environ. Sci. Technol. 46, 3369-3376.

IAEA, 2001. Manual of Acid in situ Leach Uranium Mining Technology: IAEATECDOC-1239. International Atomic Energy Association, Vienna, 294 p.

IAEA, 2005. Guidebook on Environmental Impact Assessment for in situ Leach Mining Projects: IAEA-TECDOC-1428. International Atomic Energy Association, Vienna, $170 \mathrm{p}$.

IAEA, 2009a. Establishment of Uranium Mining and Processing Operations in the Context of Sustainable Development: IAEA Nuclear Energy Series. International Atomic Energy Association, Vienna, 70 p.

IAEA, 2009b. World Distribution of Uranium Deposits (UDEPO) with Uranium Deposit Classification: IAEA-TECDOC-1629. International Atomic Energy Association, Vienna, 117 p.

Ilton, E.S., Haiduc, A., Moses, C.O., Heald, S.M., Elbert, D.C., Veblen, D.R., 2004 Heterogeneous reduction of uranyl by micas: crystal chemical and solution controls. Geochim. Cosmochim. Acta 68, 2417-2435.

Ilton, E.S., Haiduc, A., Cahill, C.L., Felmy, A.R., 2005. Mica surfaces stabilize pentavalent uranium. Inorg. Chem. 44, 2986-2988.

Ilton, E.S., Heald, S.M., Smith, S.C., Elbert, D., Liu, C.X., 2006. Reduction of uranyl in the interlayer region of low iron micas under anoxic and aerobic conditions. Environ. Sci. Technol. 40, 5003-5009. 
Jambor, J.L., Nordstrom, D.K., Alpers, C.N., 2000. Metal-sulfate salts from sulfide mineral oxidation. In: Alpers, C.N., Jambor, J.L., Nordstrom, D.K. (Eds.), Sulfate Minerals - Crystallography, Geochemistry, and Environmental Significance, Reviews in Mineralogy and Geochemistry. Mineralogical Society of America, Chantilly, Virginia, pp. 303-350.

Jang, J.H., Dempsey, B.A., Burgos, W.D., 2008. Reduction of U(VI) by Fe(II) in the presence of hydrous ferric oxide and hematite: effects of solid transformation surface coverage, and humic acid. Water Res. 42, 2269-2277.

Jarrell, J.P., 2004. Liquid Effluent Treatment Initiatives at the Key Lake Uranium Mine, Sakatchewan, Canada, 1996-2000: IAEA-TECDOC-1419. International Atomic Energy Agency, Vienna, pp. 45-73.

Jenk, U., Zimmerman, U., Ziegenbalg, G., 2006. The use of $\mathrm{BaSO}_{4}$ supersaturated solutions for the in situ immobilization of heavy metals in the abandoned Wismut Gmbh uranium mine at Königstein. In: Merkel, B., Hasche-Berger, A. (Eds.), Uranium in the Environment: Mining Impacts and Consequences. Springer, Berlin, pp. 723-727.

Jerden Jr, J.L., Sinha, A.K., 2003. Phosphate-based immobilization of uranium in an oxidizing bedrock aquifer. Appl. Geochem. 18, 823-843.

Jianguo, Z., Shaoqing, C., Sun, R., Jing, Q., 2004. Analysis and Evaluation of Water Coming from Several Uranium Processing Areas: IAEA-TECDOC-1419. International Atomic Energy Agency, Vienna, pp. 95-105.

Johnson, K., Neumann, M., 1986. Geochemical model of uranium and selenium in an aquifer disturbed by in situ uranium mining. Proceedings of the 8th Annua Symposium on Geotechnical and Geohydrological Aspects of Waste Management. Ft. Collins, CO, pp. 447-455.

Joner, E.J., Munier-Lamy, C., Gouget, B., 2007. Bioavailability and microbial adaptation to elevated levels of uranium in an acid, organic topsoil forming on an old mine spoil. Environ. Toxicol. Chem. 26, 1644-1648.

ordan, F., Jody Waugh, W., Glenn, E.P., Sam, L., Thompson, T., Lewis Thompson, T. 2008. Natural bioremediation of a nitrate-contaminated soil-and-aquife system in a desert environment. J. Arid Environ. 72, 748-763.

Kalin, M., Kießig, G., Küchler, A., 2002. Ecological water treatment processes for underground uranium mine water: progress after three years of operating constructed wetland. In: Merkel, B., Planer-Friedrich, B., Wolkersdorfer, C. (Eds.), Uranium in the Aquatic Environment. Springer, Berlin, pp. 587-596.

Kalinowski, B.E., Johnsson, A., Arlinger, J., Pedersen, K., Odegaard-Jensen, A., Edberg, F. 2006. Microbial mobilization of uranium from shale mine waste. Geomicrobiol J. 23, 157-164.

Karnachuk, O., Kurochkina, S., Tuovinen, O., 2002. Growth of sulfate-reducing bacteria with solid-phase electron acceptors. Appl. Microbiol. Biotechnol. 58, 482-486.

Karp, K.E., Metzler, D.R., 2006. Moab, Utah, UMTRA Site: the last large uranium mil tailings pile to be cleaned up in the United States: in uranium in the environment. In: Merkel, B., Hasche-Berger, A. (Eds.), Mining Impacts and Consequences. Springer, Berlin, pp. 671-682.

Kelly, J.M., Janz, D.M., 2009. Assessment of oxidative stress and histopathology in juvenile northern pike (Esox lucius) inhabiting lakes downstream of a uranium mill. Aquat. Toxicol. 92, 240-249.

Kelly, S.D., Newville, M.G., Cheng, L., Kemner, K.M., Sutton, S.R., Fenter, P., Sturchio N.C., Spötl, C., 2003. Uranyl incorporation in natural calcite. Environ. Sci. Technol. 37, 1284-1287.

Kipp, G.G., Stone, J.J., Stetler, L.D., 2009. Arsenic and uranium transport in sediments near abandoned uranium mines in Harding County, South Dakota. Appl Geochem. 24, 2246-2255.

Kochenov, A.V., Korolev, K.G., Dubinchuk, V.T., Medvedev, Y.L., 1977. Experimental data on the conditions of precipitation of uranium from aqueous solutions. Geokhimiya 11, 1711-1716 (translated from Russian 1978).

Koide, M., Bruland, K., Goldberg, E.D., 1976. ${ }^{226}$ Ra chronology of a coastal marine sediment. Earth Planet. Sci. Lett. 31, 31-36.

Komlos, J., Kukkadapu, R.K., Zachara, J.M., Jaffé, P.R., 2007. Biostimulation of iron reduction and subsequent oxidation of sediment containing $\mathrm{Fe}$-silicates and $\mathrm{Fe}-$ oxides: effect of redox cycling on Fe(III) bioreduction. Water Res. 41, 2996 3004.

Komlos, J., Mishra, B., Lanzirotti, A., Myneni, S.C.B., Jaffé, P.R., 2008a. Real-time speciation of uranium during active bioremediation and U(IV) reoxidation. J. Environ. Eng. 134, 78-86.

Komlos, J., Moon, H.S., Jaffé, P.R., 2008b. Effect of sulfate on the simultaneous bioreduction of iron and uranium. J. Environ. Qual. 37, 2058-2062.

Kramer, D., 2010. Concern grows over China's dominance of rare earth metals. Phys. Today 63, 22-24.

Křepelová, A., Sachs, S., Bernhard, G., 2006. Uranium(VI) sorption on kaolinite in the presence and absence of humic acid. Radiochim. Acta 94, 825-833.

Krumhansl, J.L., Brady, P.V., Beauheim, R.L., Kanney, J.F., McKenna, S.A., Arnold, B.W., 2009. Inherently Safe in situ Uranium Recovery: SAND2008-6688. Sandia National Laboratory, Albuquerque, NM.

Küchler, A., Kiessig, G., Kunze, C., 2006. Passive biological treatment systems of mine waters at WISMUT Sites. In: Merkel, B., Hasche-Berger, A. (Eds.), Uranium in the Environment: Mining Impacts and Consequences. Springer, Berlin, pp. 329-340.

Kunze, C., Kiessig, G., Kuechler, A., 2007. Management of passive biological water treatment systems for mine effluents. In: Marmiroli, N., Samotokin, B. Marmiroli, M. (Eds.), Advanced Science and Technology for Biological Decontamination of Sites Affected by Chemical and Radiological Nuclear Agents. Springer, Dordrecht, pp. 177-195.
Kyle, J.H., 2012. Review of trace toxic elements (Pb, Cd, Hg, As, Sb, Bi, Se, Te) and their deportment in gold processing: Part II: Deportment in gold ore processing by cyanidation. Hydrometallurgy 111-112, 10-21.

Landa, E.R., 1980. Isolation of uranium mill tailings and their component radionuclides from the biosphere - some earth science perspectives. U.S. Geological Survey Circular 814, 32.

Landa, E.R., 1999. Geochemical and biogeochemical controls on element mobility in and around uranium mill tailings. Rev. Econ. Geol. 6B, 527-538.

Landa, E.R., 2003. Mobilization of radionuclides from uranium mill tailings and related waste materials in anaerobic environments. J. Radioanal. Nucl. Chem. $255,559-563$.

Landa, E.R., 2004. Uranium mill tailings: nuclear waste and natural laboratory for geochemical and radioecological investigations. J. Environ. Radioact. 77, 1-27.

Landa, E.R., 2005. Microbial biogeochemistry of uranium mill tailings. Adv. Appl. Microbiol., 113-130.

Landa, E.R., 2007. Naturally occurring radionuclides from industrial sources: characteristics and fate in the environment. In: Shaw, G. (Ed.), Radioactivity in the Terrestrial Environment. Elsevier, pp. 211-237.

Landa, E.R., Miller, C.L., Updegraff, D.M., 1986. Leaching of ${ }^{226}$ Ra from U mill tailings by sulfate-reducing bacteria. Health Phys. 51, 509-518.

Landa, E.R., Stieff, L.R., Germani, M.S., Tanner, A.B., Evans, J.R., 1994. Intense alphaparticle emitting crystallites in uranium mill wastes. Nucl. Geophys. 8, 443-454.

Landa, E.R., Gray, J.R., 1995. U.S. Geological Survey research on the environmental fate of uranium mining and milling wastes. Environ. Geol. 26, 19-31.

Landa, E.R., Le, A.H., Luck, R.L., Yeich, P.J., 1995. Sorption and coprecipitation of trace concentrations of thorium with various minerals under conditions simulating an acid uranium mill effluent environment. Inorg. Chim. Acta 229, 247-252.

Langmuir, D., 1978. Uranium solution-mineral equilibria at low temperatures with applications to sedimentary ore deposits. Geochim. Cosmochim. Acta 42, 547569.

Langmuir, D., 1997. Aqueous Environmental Geochemistry. Prentice Hall, Upper Saddle River, New Jersey, p. 600.

Langmuir, D., Mahoney, J., MacDonald, A., Rowson, J., 1999. Predicting arsenic concentrations in the porewaters of buried uranium mill tailings. Geochim. Cosmochim. Acta 63, 3379-3394.

Langmuir, D., Mahoney, J., Rowson, J., 2006. Solubility products of amorphous ferric arsenate and crystalline scorodite $\left(\mathrm{FeAsO}_{4} \cdot 2 \mathrm{H}_{2} \mathrm{O}\right)$ and their application to arsenic behavior in buried mine tailings. Geochim. Cosmochim. Acta 70, 29422956.

Latta, D.E., Boyanov, M.I., Kemner, K.M., O’Loughlin, E.J., Scherer, M.M., 2012a. Abiotic reduction of uranium by Fe(II) in soil. Appl. Geochem. 27, 1512-1524.

Latta, D.E., Gorski, C.A., Boyanov, M.I., O'Loughlin, E.J., Kemner, K.M., Scherer, M.M., 2012b. Influence of magnetite stoichiometry on U(VI) reduction. Environ. Sci. Technol. 46, 778-786.

Lenhart, J.J., Honeyman, B.D., 1999. Uranium(VI) sorption to hematite in the presence of humic acid. Geochim. Cosmochim. Acta 63, 2891-2901.

Li, L., Steefel, C.I., Williams, K.H., Wilkins, M.J., Hubbard, S.S., 2009. Mineral transformation and biomass accumulation associated with uranium bioremediation at Rifle, Colorado. Environ. Sci. Technol. 43, 5429-5435.

Li, L., Gawande, N., Kowalsky, M.B., Steefel, C.I., Hubbard, S.S., 2011. Physiochemical heterogeneity controls on uranium bioreduction rates at the field scale. Environ. Sci. Technol. 45, 9959-9966.

Liddell, K.C., Bautista, R.G., 1995. Simulation of in situ uraninite leaching - Part II. The effects of ore grade and deposit porosity. Metall. Mater. Trans. B 26, 687694

Liger, E., Charlet, L., Van Cappellen, P., 1999. Surface catalysis of uranium(VI) reduction by iron(II). Geochim. Cosmochim. Acta 63, 2939-2955.

Liu, C., Zachara, J.M., Zhong, L., Kukkadupa, R., Szecsody, J.E., Kennedy, D.W., 2005. Influence of sediment bioreduction and reoxidation on uranium sorption. Environ. Sci. Technol. 39, 4125-4133.

Liu, J., Zhou, Y., Liu, Y., Sun, Z.X., 2010. Study on some influence factors of in situ leaching of uranium mining in Shihongtan deposit. In: Birkle, P., TorresAlvarado (Eds.), Water-Rock Interaction Proceedings. CRC Press.

Livens, F.R. et al., 2004. X-Ray Absorption spectroscopy studies of reactions of technetium, uranium and neptunium with mackinawite. J. Environ. Radioact. $74,211-219$.

Lottermoser, B.G., Ashley, P.M., 2005. Tailings dam seepage at the rehabilitated Mary Kathleen uranium mine, Australia. J. Geochem. Explor. 85, 119-137.

Lovley, D.R., Phillips, E.J.P., Gorby, Y.A., Landa, E.R., 1991. Microbial reduction of uranium. Nature 350, 413-416.

Lovley, D.R., Phillips, E.J.P., 1992. Reduction of uranium by Desulfovibrio desulfuricans. Appl. Environ. Microbiol. 58, 850-856.

Lovley, D.R., Widman, P.K., Woodward, J.C., Phillips, E.J., 1993. Reduction of uranium by cytochrome c3 of Desulfovibrio vulgaris. Appl. Environ. Microbiol. 59, 3572 3576.

Lovley, D.R., Coates, J.D., Blunt-Harris, E.L., Phillips, E.J.P., Woodward, J.C., 1996. Humic substances as electron acceptors for microbial respiration. Nature 382, 445-448.

Mackin, P.C., Daruwalla, D., Winterle, J., Smith, M., Pickett, D.A, 2001. A Baseline Risk-informed, Performance-based Approach for in situ Leach Uranium Extraction Leases: NUREG/CR-6733. Nuclear Regulatory Commission, Washington, D.C., 197 p.

Mahoney, J., Langmuir, D., Gosselin, N., Rowson, J., 2005. Arsenic readily released to pore waters from buried mill tailings. Appl. Geochem. 20, 947-959. 
Mahoney, J., Slaughter, M., Langmuir, D., Rowson, J., 2007. Control of As and Ni releases from a uranium mill tailings neutralization circuit: solution chemistry, mineralogy and geochemical modeling of laboratory study results. Appl. Geochem. 22, 2758-2776.

Majs, F., 2011. Potential effects of applying phosphate amendments to imobilize soil contaminants. J. Environ. Qual. 40, 1135-1142.

Marshall, M.J., Beliaev, A.S., Dohnalkova, A.C., Kennedy, D.W., Shi, L., Wang, Z., Boyanov, M.I., Lai, B., Kemner, K.M., McLean, J.S., Reed, S.B., Culley, D.E., Bailey, V.L., Simonson, C.J., Saffarini, D.A., Romine, M.F., Zachara, J.M., Fradrichson, J.K., 2006. C-type cytochrome-dependent formation of U(IV) nanoparticles by Shewanella oneidensis. PLoS Biol. 4, 1324-1333.

Martin, A.J., Crusius, J., McNee, J.J., Yanful, E.K., 2003. The mobility of radium-226 and trace metals in pre-oxidized subaqueous uranium mill tailings. Appl. Geochem. 18, 1095-1110.

Mason, C., 1998. Carbonate Leaching of Uranium: LA-UR-98-3136. Los Alamos National Laboratory, Los Alamos, NM, 13 p.

Mathur, A., Dwivedy, K., 1988. A biogenic approach to the treatment of uranium mill effluents. Uranium 4, 385-394.

McCready, R.G.L., Gould, W.D., 1990. Bioleaching of uranium. In: Ehrlich, H.L., Brierley, C.L. (Eds.), Microbial Mineral Recovery. McGraw-Hill, New York, NY, pp. 107-125.

McLemore, V.T., Turner, D., 2006. Sustainable development and exploration. Min. Eng. 58, 56-61.

McLemore, V., 2007. Uranium Resources in New Mexico: SME Annual Meeting, Denver, CO, February 25-26, 2007, 13 p.

Mehta, T., Coppi, M.V., Childers, S.E., Lovley, D.R., 2005. Outer membrane c-type cytochromes required for $\mathrm{Fe}(\mathrm{III})$ and $\mathrm{Mn}(\mathrm{IV})$ oxide reduction in Geobacter sulfurreducens. Appl. Environ. Microbiol. 71, 8634-8641.

Merroun, M.L., Selenska-Pobell, S., 2008. Bacterial interactions with uranium: an environmental perspective. J. Contam. Hydrol. 102, 285-295.

Miletto, M., Williams, K.H., N'Guessan, A.L., Lovley, D.R., 2011. Molecular analysis of the metabolic rates of discrete subsurface populations of sulfate reducers. Appl. Environ. Microbiol. 77, 6502-6509.

Miller, C.L., Landa, E.R., Updegraff, D.M., 1987. Ecological aspects of microorganisms inhabiting uranium mill tailings. Microb. Ecol. 14, 141-155.

Miller, W., Alexander, R., Chapman, N., McKinley, I., Smellie, J., 1994. Natural Analogue Studies in the Geological Disposal of Radioactive Wastes. Elsevier, The Netherlands, Amsterdam, 395 p.

Missana, T., Maffiotte, C., García-Gutiérrez, M., 2003. Surface reactions kinetics between nanocrystalline magnetite and uranyl. J. Colloid Interface Sci. 261, $154-160$.

Mohagheghi, A., Goldhaber, M.B., 1982. Kinetics of uranyl ion reduction by aqueous sulfide at $35^{\circ} \mathrm{C}$. Geol. Soc. Am. Abstr. 14, 568 .

Molchanov, A., Soroka, Y., Isayeva, N.I., 2004. Treatment of Liquid Effluent from Uranium Enterprises in Ukraine: IAEA-TECDOC-1419. International Atomic Energy Agency report, Vienna.

Moldovan, B.J., Hendry, M.J., 2005. Characterizing and quantifying controls on arsenic solubility over a $\mathrm{pH}$ range of $1-11$ in a uranium mill-scale experiment. Environ. Sci. Technol. 39, 4913-4920.

Moldovan, B.J., Jim Hendry, M., Harrington, G.A., 2008. The arsenic source term for an in-pit uranium mine tailings facility and its long term impact on the regional groundwater. Appl. Geochem. 23, 1437-1450.

Moon, H.S., Komlos, J., Jaffé, P.R., 2009. Biogenic U(IV) Oxidation by dissolved oxygen and nitrate in sediment after prolonged $\mathrm{U}(\mathrm{VI}) / \mathrm{Fe}(\mathrm{III}) / \mathrm{SO}_{4}^{2-}$ reduction. J. Contam. Hydrol. 105, 18-27.

Morrison, S.J., Metzler, D.R., Carpenter, C.E., 2001. Uranium precipitation in a permeable reactive barrier by progressive irreversible dissolution of zerovalent iron. Environ. Sci. Technol. 35, 385-390.

Morrison, S.J., Metzler, D.R., Dwyer, B.P., 2002. Removal of as, Mn, Mo, Se, U, V and $\mathrm{Zn}$ from groundwater by zero-valent iron in a passive treatment cell: reaction progress modeling. J. Contam. Hydrol. 56, 99-116.

Moyes, L.N., Parkman, R.H., Charnock, J.M., Vaughan, D.J., Livens, F.R., Hughes, C.R., Braithwaite, A., 2000. Uranium uptake from aqueous solution by interaction with goethite, lepidocrocite, muscovite, and mackinawite: an X-ray absorption spectroscopy study. Environ. Sci. Technol. 34, 1062-1068.

Mudd, G.M., Diesendorf, M., 2008. Sustainability of uranium mining and milling: toward quantifying resources and eco-efficiency. Environ. Sci. Technol. 42 2624-2630.

Murakami, T., Ohnuki, T., Isobe, H., Sato, T., 1997. Mobility of uranium during weathering. Am. Mineral. 82, 888-899.

Muscatello, J.R., Bennett, P.M., Himbeault, K.T., Belknap, A.M., Janz, D.M., 2006. Larval deformities associated with selenium accumulation in northern pike (Esox lucius) exposed to metal mining effluent. Environ. Sci. Technol. 40, 65066512.

Muscatello, J.R., Janz, D.M., 2009. Selenium accumulation in aquatic biota downstream of a uranium mining and milling operation. Sci. Total Environ. 407, 1318-1325.

N'Guessan, A.L., Vrionis, H.A., Resch, C.T., Long, P.E., Lovley, D.R., 2008. Sustained removal of uranium from contaminated groundwater following stimulation of dissimilatory metal reduction. Environ. Sci. Technol. 42, 2999-3004.

Naftz, D.L., Feltcorn, E.M., Fuller, C.C., Wilhelm, R.G., Davis, J.A., Morrison, S.J., Freehey, G.W., Piana, M.J., Rowland, R.C., Blue, J.E., 2000. Field demonstration of permeable reactive barriers to remove dissolved uranium from groundwater, Fry Canyon, Utah, September 1997 through September 1998, Interim Report. EPA 402-C-00-01. Environmental Protection Agency, Washington, D.C., p. 89.
Nordstrom, D.K., 2000. Advances in the hydrogeochemistry and microbiology of acid mine waters. Int. Geol. Rev. 42, 499-515.

Noubactep, C., 2008. A critical review on the process of contaminant removal in $\mathrm{Fe}^{0}$ $\mathrm{H}_{2} \mathrm{O}$ systems. Environ. Technol. 29, 909-920.

O'Loughlin, E.J., Kelly, S.D., Cook, R.E., Csencsits, R., Kemner, K.M., 2003. Reduction of $\mathrm{U}(\mathrm{VI})$ by mixed iron(II/III) hydroxide (green rust): formation of $\mathrm{UO}_{2}$ nanoparticles. Environ. Sci. Technol. 37, 721-727.

O'Loughlin, E.J., Kelly, S.D., Kemner, K.M., 2010. XAFS investigation of the interactions of $\mathrm{U}(\mathrm{VI})$ with secondary mineralization products from the bioreduction of Fe(III) oxides. Environ. Sci. Technol. 44, 1656-1661.

OCED, 1983. Uranium Extraction Technology: Current practice and new developments in ore processing. Organisation for Economic Co-operation and Development, Paris, 270 p.

Orellana, R., Leavitt, J.J., Comolli, L.R., Csencsits, R., Janot, N., Flanagan, K.A., Grey, A.S., Leang, C., Isallalen, M., Mester, T., Lovley, D.R., 2013. U(VI) reduction by diverse outer surface c-type cytochromes of Geobacter sulfurreducens. Appl. Environ. Microbiol. 79, 6369-6374.

Osiensky, J.L., Peterson, K.A., Williams, R.E., 1988. Solute transport simulation of aquifer restoration after in situ uranium mining. Ground Water Monit. Rev. 8, $137-144$.

Osiensky, J.L., Williams, R.E., 1990. Factors affecting efficient aquifer restoration at in situ uranium mine sites. Ground Water Monit. Rev. 10, 107-112.

Otton, J.K., Gallegos, T.J., Van Gosen, B.S., Johnson, R.H., Zielinski, R.A., Hall, S.M., Arnold, L.R., Yager, D.B., 2010. Effects of 1980s uranium mining in the Kanab Creek area of northern Arizona. In: Alpine, A.E. (Ed.), Hydrological, geological, and biological site characterization of breccia pipe uranium deposits in northern Arizona, U.S. Geological Survey Scientific Investigations Report 2010-5025. USGS, Reston, Virginia, p. 353.

Owen, D.E., Otton, J.K., 1995. Mountain wetlands: efficient uranium filters potential impacts. Ecol. Eng. 5, 77-93.

Paul, J.M., Venuto, P.B., Lundahl, R.B., 1982. In-situ leaching of south Texas uranium ores: III. Post leach assessment of recovery and sweep efficiency: AIME Society of Petroleum Engineers Annual Technical Conference and Exhibition, New Orleans, LA, USA, $9 \mathrm{p}$.

Papanicolaou, F., Antoniou, S., Pashalidis, I., 2010. Redox chemistry of sulphate and uranium in a phosphogypsum tailings dump. J. Environ. Radioact. 101, 601-605.

Payne, T.E., Davis, J.A., Waite, T.D., 1996. Uranium adsorption on ferrihydrite effects of phosphate and humic acid. Radiochim. Acta 74, 239-243.

Payne, R.B., Gentry, D.M., Rapp-Giles, B.J., Casalot, L., Wall, J.D., 2002. Uranium reduction by Desulfovibrio desulfuricans strain G20 and a cytochrome c3 Mutant. Appl. Environ. Microbiol. 68, 3129-3132.

Peacey, V., Yanful, E.K., Payne, R.B., 2002. Field study of geochemistry and solute fluxes in flooded uranium mine tailings. Can. Geotech. J. 39, 357-376.

Pelizza, M.S., 2008. In situ recovery of uranium. Southwest Hydrol. 7, 28-29 \& 34.

Peterson, M.J., Smith, J.G., Southworth, G.R., Ryon, M.G., Eddlemon, G.K., 2002. Trace element contamination in benthic macroinvertebrates from a small stream near a uranium mill tailings site. Environ. Monit. Assess. 74, 193-208.

Phillips, E.J.P., Landa, E.R., Lovley, D.R., 1995. Remediation of uranium contaminated soils with bicarbonate extraction and microbial $\mathrm{U}(\mathrm{VI})$ reduction. J. Ind Microbiol. 14, 203-207.

Pichler, T., Hendry, M.J., Hall, G.E.M., 2001. The mineralogy of arsenic in uranium mine tailings at the Rabbit Lake in-pit facility, northern Saskatchewan, Canada. Environ. Geol. 40, 495-506.

Pilegaard, K., 1990. Preliminary Environmental Impact Statement for the Kvanefjeld Uranium Mine: Riso Report M-2875. Riso National Laboratory, Roskilde, Denmark., 123 p.

Plant, J.A., Simpson, P.R., Smith, B., Windley, B.F., 1999. Uranium ore deposits products of the radioactive Earth: Uranium. In: Burns, P.C., Finch, R. (Eds.), Mineralogy, Geochemistry, and the Environment, vol. 38. Mineralogical Society of America, Washington, D.C, pp. 254-319.

Plumlee, G.S., Nash, J.T., 1995. Geoenvironmental Models of Mineral Deposits Fundamentals and Applications: Open-File Report 95-831. USGS, Denver, CO, 272 p.

Pyle, G.G. 2000. The Toxicity and Bioavailability of Nickel and Molybdenum to Standard toxicity-test Fish Species and Fish Species Found in Northern Canadian Lakes. University of Saskatchewan, Saskatoon, Ph.D. thesis. <http:// library2.usask.ca/theses/available/etd-10212004-002852/> (accessed 05.12.12).

Pyle, G.G., Swanson, S.M., Lehmkuhl, D.M., 2001. Toxicity of uranium minereceiving waters to caged fathead minnows, Pimephales promelas. Ecotoxicol Environ. Safety 48, 202-214.

Rai, D., Felmy, A.R., Ryan, J.L., 1990. Uranium(IV) hydrolysis constants and solubility product of $\mathrm{UO}_{2} \cdot x \mathrm{H}_{2} \mathrm{O}_{(\mathrm{am})}$. Inorg. Chem. 29, 260-264.

Read, D., Bennett, D.G., Hooker, P.J., Ivanovich, M., Longworth, G., Milodowski, A.E. Noy, D.J., 1993. The migration of uranium into peat-rich soils at Broubster, Caithness, Scotland, U.K. J. Contam. Hydrol. 13, 291-308.

Regenspurg, S., Schild, D., Schäfer, T., Huber, F., Malmström, M.E., 2009. Removal of uranium(VI) from aqueous phase by iron(II) minerals in presence of bicarbonate. Appl. Geochem. 24, 1619-1625.

Regenspurg, S., Margot-Roquier, C., Harfouche, M., Froidevaux, P., Steinmann, P., Bernier-Latmani, R., 2010. Speciation of naturally accumulated uranium in an organic-rich soil of an alpine region (Switzerland). Geochim. Cosmochim. Acta 74, 2082-2098.

Reguera, G., 2012. Electron transfer at the cell-uranium interface in Geobacter spp. Biogeochem. Soc. Trans. 40, 1227-1232. 
Renshaw, J.C., Butchins, L.J.C., Livens, F.R., May, I., Charnock, J.M., Lloyd, J.R., 2005 Bioreduction of uranium: environmental implications of a pentavalent intermediate. Environ. Sci. Technol. 39, 5657-5660.

Reynolds, R.L., Goldhaber, M.B., 1983. Iron disulfide minerals and the genesis of rolltype uranium deposits. Econ. Geol. 78, 105-120.

Ricciardi, F. et al., 2009. Is chemical contamination linked to the diversity of biological communities in rivers? Trends Anal. Chem. 28, 592-602.

Ring, R.J., Holden, P., McCulloch, J.K., Tapsell, G.J., Collier, D.E., Russell, R. Macnaughton, S., Marshall, K., Stimson, D., 2004. Treatment of Liquid Effluent from Uranium Mines and Mills during and after Operation: IAEA-TECDOC-1419. International Atomic Energy Agency, Vienna.

Romano, F.M.,Prol-Ledesma, R.M., Canet, C., Alvares, L.N., Perez-Vázquez, R.P., 2010 Acid drainage at the inactive Santa Lucia Mine, western Cuba: natural attenuation of arsenic, barium and lead, and geochemical behavior of rare earth elements. Appl. Geochem. 25, 716-727.

Saskatchewan-Environment, 2006. Surface Water Quality Objectives (Interim Edition): EPB-356, Saskachewan Environment, Regina, SK, 11 p.

Schechter, R.S., Lake, L.W., Guilinger, T.R., Price, J.G., Bobeck, P., 1985. Development of environmentally attractive leachants. A Minitest of an in situ Uranium Leach Solution: USGS Open File Report 86-13, vol. 4. USGS, Washington, DC,, p. 151.

Scheinost, A.C., Henning, C., Somogyi, A., Martinez-Craido, G., Knappik, R., 2006 Uranium speciation in two freital mine tailing samples. In: Merkel, B., HascheBerger, A. (Eds.), EXAFS, M-XRD, M-XRF Results: Uranium in the Environment, Mining Impacts and Consequences. Springer, Berlin, pp. 117-126.

Schlotz, N., Scholtz, O.F., Potgieter, G.P., 2006. Potential environmental impact resulting from inadequate remediation of uranium mining in Karoo uranium province, South Africa. In: Merkel, B., Hasche-Berger, A. (Eds.), Uranium in the Environment: Mining impacts and consequences. Springer, Berlin, pp. 789-799.

Schneider, P., Neitzel, P.L., Osenbruck, K., Noubacteb, C., Merkel, B., Hurst, S., 2001 In situ treatment of radioactive mine water using reactive materials - results of laboratory and field experiments in uranium ore mines in Germany. Acta Hydrochim. Hydrobiol. 29, 129-138.

Schoeppner, J., 2008. Groundwater remediation from uranium mining in New Mexico. Southwest Hydrol. 7, 22-23 \& 34.

Schofield, E.J., Veeramani, H., Sharp, J.O., Suvorova, E., Bernier-Latmani, R., Mehta, A. Stahlman, J., Webb, S.M., Clark, D.L., Conradson, S.D., Ilton, E.S., Bargar, J.R., 2008 Structure of biogenic uraninite produced by Shewanella oneidensis strain MR-1. Environ. Sci. Technol. 42, 7898-7904.

Schrenk, M.O., Edwards, K.J., Goodman, R.M., Hamers, R.J., Banfield, J.F., 1998 Distribution of Thiobacillus ferrooxidans and Leptospirillum ferrooxidans: implications for generation of acid mine drainage. Science 279, 1519-1522.

Schröder-Wolthoorn, A., Kuitert, S., Dijkman, H., Huisman, J.L., 2008. Application of sulfate reduction for the biological conversion of anglesite $\left(\mathrm{PbSO}_{4}\right)$ to galena (PbS). Hydrometallurgy 94, 105-109.

Seal, R.R., Foley, N.K., Wanty, R.B., 1995. Introduction to Geoenvironmental Models of Mineral Deposits: USGS Open File Report 95-831. USGS, Denver, 272 p.

Senko, J.M., Istok, J.D., Suflita, J.M., Krumholz, L.R., 2002. In situ evidence for uranium immobilization and remobilization. Environ. Sci. Technol. 36, 1491-1496.

Senko, J.M., Campbell, B.S., Henriksen, J.R., Elshahed, M.S., Dewers, T.A., Krumholz, L.R., 2004. Barite deposition resulting from phototrophic sulfide-oxidizing bacterial activity. Geochim. Cosmochim. Acta 68, 773-780.

Senko, J.M., Mohamed, Y., Dewers, T.A., Krumholz, L.R., 2005a. Role for Fe(III) minerals in nitrate-dependent microbial U(IV) oxidation. Environ. Sci. Technol 39, 2529-2536.

Senko, J.M., Suflita, J.M., Krumholz, L.R., 2005b. Geochemical controls on microbia nitrate-dependent U(IV) oxidation. Geomicrobiol J. 22, 371-378.

Senko, J.M., Kelly, S.D., Dohnalkova, A.C., McDonough, J.T., Kemner, K.M., Burgos, W.D. 2007. The effect of U(VI) bioreduction kinetics on subsequent reoxidation of biogenic U(IV). Geochim. Cosmochim. Acta 71, 4644-4654.

Sharp, J.O., Schofield, E.J., Veeramani, H., Suvorova, E.I., Kennedy, D.W., Marshall, M.J., Mehta, A., Bargar, J.R., Bernier-Latmani, R., 2009. Structural similaritie between biogenic uranites produced by phylogenetically and metabolically diverse bacteria. Environ. Sci. Technol. 43, 8295-8301.

Sharp, J.O., Lezama-Pacheco, J.S., Schofield, E.J., Junier, P., Ulrich, K.E., Chinni, S. Veeramani, H., Margo-Roquier, C., Webb, S.M., Tebo, B.M., Giammar, D.E. Bargar, J.R., Bernier-Latmani, R., 2011. Uranium speciation and stability after reductive immobilization in aquifer sediments. Geochim. Cosmochim. Acta 75 6497-6510.

Shelobolina, E.S., Coppi, M.V., Korenevsky, A.A., DiDonato, L.N., Sullivan, S.A., Xu Konishi, H., Leang, C., Butler, J.E., Kim, B.C., Lovley, D.R., 2007. Importance of ctype cytochromes for $\mathrm{U}(\mathrm{VI})$ reduction by Geobacter sulfurreducens. BMC Microbiol. 7, 16.

Sheng, L., Fein, J.B., 2014. Uranium reduction by Shewanella oneidensis MR-1 as a function of $\mathrm{NaHCO} 3$ concentration: surface complexation control of reduction kinetics. Environ. Sci. Technol. 48, 3768-3775.

Shuck, D., 1979. Overview of solution mining. In: Morse, J. (Ed.), Uranium Resource Technology Seminar II. Colorado School of Mines, Golden, CO, pp. 169-189.

Singer, D.M., Chatman, S.M., Ilton, E.S., Rosso, K.M., Banfield, J.F., Waychunas, G.A., 2012. Identification of simultaneous U(UI) sorption complexes and U(IV) nanoprecipitates on the magnetite (111) surface. Environ. Sci. Technol. 46, 3811-3820.

Singer, D.M., Farges, F., Brown Jr, G.E., 2009. Biogenic nanoparticulate $\mathrm{UO}_{2}$ synthesis, characterization, and factors affecting surface reactivity. Geochim. Cosmochim. Acta 73, 3593-3611.
Singh, A., Ulrich, K.U., Giammar, D.E., 2010. Impact of phosphate on U(VI) immobilization in the presence of goethite. Geochim. Cosmochim. Acta 74, 6324-6343.

Skomurski, F.N., Illton, E.S., Engelhard, M.H., Arey, B.W., Rosso, K.M., 2011. Heterogeneous reduction of $\mathrm{U}^{6+}$ by structural $\mathrm{Fe}^{2+}$ from theory and experiment. Geochim. Cosmochim. Acta 75, 7277-7290.

Soudek, P., Petř́ik, P., Vágner, M., Tykva, R., Plojhar, V., Petrová, S., Vaněk, T., 2007. Botanical survey and screening of plant species which accumulate ${ }^{226} \mathrm{Ra}$ from contaminated soil of uranium waste depot. Eur. J. Soil Biol. 43, 251-261.

Soudek, P., Petrová, T., Benešová, D., Kotyza, J., Vágner, M., Vaňková, R., Vaněk, T., 2010. Study of soil-plant transfer of ${ }^{226}$ Ra under greenhouse conditions. J. Environ. Radioact. 101, 446-450.

Stewart, C.L., Reimann, L.J., Swapp, S.M., 2000. Mineralogic Considerations for Uranium in situ Leach Mining: A Preliminary Study of Uranium and Associated Mineralogy of Roll-front Uranium Deposits in Wyoming and Nebraska. Wyoming Geological Association Guidebook, 5th Field Conference, p. 155-175.

Stewart, B.D., Nico, P.S., Fendorf, S., 2009. Stability of uranium incorporated into Fe (hydr)oxides under fluctuating redox conditions. Environ. Sci. Technol. 43, 4922-4927.

Stewart, B.D., Mayes, M.A., Fendorf, S., 2010. Impact of uranyl-calcium-carbonato complexes on uranium(VI) adsorption to synthetic and natural sediments. Environ. Sci. Technol. 44, 928-934.

Štrok, M., Smodiš, B., 2010. Fractionation of natural radionuclides in soils from the vicinity of a former uranium mine Žirovski Vrh, Slovenia. J. Environ. Radioact. $101,22-28$.

Strom, E.T. Vogt, T.C., 1987. In situ leaching of Crownpoint, NM, uranium ore: Part 7-laboratory study of chemical agents for molybdenum restoration. J. Petrol. Technol. 39, 1301-1305.

Stucker, V.K., Williams, K.H., Robbins, M.J., Ranville, J.F., 2013. Arsenic geochemsitry in a biostimulated aquifer: an aqueous speciation study. Environ. Toxicol. Chem. 32, 1216-1223.

Stylo, M., Alessi, D.S., Shao, P.P., Lezama-Pacheco, J.S., Bargar, J.R., Bernier-Latmani, R., 2013. Biogeochemical controls on the product of microbial U(VI) reduction. Environ. Sci. Technol. 47, 12351-12358.

Sun, Z.X., Liu, J.H., Shi, W.J., 2010. Mechanism of Chemical Plugging During the in situ Leach Mining Process in Shihongtan Uranium Deposit, Xinjiang, China. Presented at Water-Rock Interaction, Guanajuato, Mexico.

Suzuki, Y., Banfield, J.F., 1999. Geomicrobiology of uranium. In: Burns, P.C., Finch, R. (Eds.), Uranium: Mineralogy, Geochemistry, and the Environment, vol. 38. Mineralogical Society of America, Washington, D.C, pp. 393-432.

Suzuki, Y., Kelly, S.D., Kemner, K.M., Banfield, J.F., 2002. Nanometre-size products of uranium bioreduction. Nature 419, 134.

Suzuki, Y., Banfield, J.F., 2004. Resistance to, and accumulation of, uranium by bacteria from a uranium-contaminated site. Geomicrobiol J. 21, 113-121.

Suzuki, Y., Suko, T., 2006. Geomicrobiological factors that control uranium mobility in the environment: update on recent advances in the bioremediation of uranium-contaminated sites. J. Mineral. Petrol. Sci. 101, 299-307.

Swart, C.J.U., Stoch, E.J., van Jaarsveld, C.F., Brink, A.B.A., 2003. The Lower Wonderfontein Spruit: an exposé. Environ. Geol. 43, 635-653.

Tagami, K., Uchida, S., 2009. Radium-226 transfer factor from soils to crops and its simple estimation method using uranium and barium concentrations. Chemosphere 77, 105-114.

Taskaev, A.I., Landa, E.R., Guryev, D.V., Golovko-Butler, N., Kraemer, T.F., 2003. Vodnyi: A long-term, low-level radiation exposure field site in Russia. Jpn. J. Health Phys. 38, 332-343.

Taylor, G., Farrington, V., Woods, P., Ring, R., Molloy, R., 2004. Client Report: Review of Environmental Impacts of the Acid in situ Leach Uranium Mining Process: CSIRO Land and Water, ADELAIDE SA, 60 p. <www.epa.sa.gov.au/pdfs/ isl_review.pdf> (accessed 05.12.12).

Thomas, P., Liber, K., 2001. An estimation of radiation doses to benthic invertebrates from sediments collected near a Canadian uranium mine. Environ. Int. 27, $341-$ 353.

Tinnacher, R.M., Nico, P.S., Davis, J.A., Honeyman, B.D., 2013. Effects of fulvic acid on uranium(VI) sorption kinetics. Environ. Sci. Technol. 47, 6214-6222.

Tokunaga, T.K., Kim, Y., Wan, J., 2009. Potential remediation approach for uraniumcontaminated groundwaters through potassium uranyl vanadate precipitation. Environ. Sci. Technol. 43, 5467-5471.

Tsezos, M., McCready, R.G.L., Bell, J.P., 1989. Continuous recovery of uranium from biologically leached solutions using immobilized biomass. Biotechnol. Bioeng. $34,10-17$.

Tsui, T.F., 1984. Mineralogical characterization of uranium ore to evaluate in situ leaching prospects. Soc. Petrol. Eng. J. 24, 563-574.

Ulrich, K.U., Singh, A., Schofield, E.J., Bargar, J.R., Veeramani, H., Sharp, J.O., BernierLatmani, R., Giammar, D.E., 2008. Dissolution of biogenic and synthetic $\mathrm{UO}_{2}$ under varied reducing conditions. Environ. Sci. Technol. 42, 5600-5606.

Ulrich, K.U., Ilton, E.S., Veeramani, H., Sharp, J.O., Bernier-Latmani, R., Schofield, E.J., Bargar, J.R., Giammar, D.E., 2009. Comparative dissolution kinetics of biogenic and chemogenic uraninite under oxidizing conditions in the presence of carbonate. Geochim. Cosmochim. Acta 73, 6065-6083.

Ulrich, K.U., Veeramani, H., Bernier-Latmani, R., Giammar, D.E., 2011. Speciationdependent kinetics of uranium(VI) bioreduction. Geomicrobiol J. 28, 396-409.

Updegraff, D.M., Douros, J.D., 1972. The relationship of microorganisms to uranium deposits. Proceedings of the Twenty-Eighth General Meeting of the Society for Industrial Microbiology. 
USDOE, 2009. Fact sheet: Monticello, Utah, Disposal and Processing Sites: US Deparment of Energy, Washington, D.C. <http://www.lm.doe.gov/Monticello/ Documents.aspx> (accessed 05.12.12).

USEPA, 1975. Water Quality Impacts of Uranium Mining and Milling Practices in the Grants Mineral Belt, New Mexico. U.S. Environmental Protection Agency, Washington, DC, $188 \mathrm{p}$.

USEPA, 2009. National Primary Drinking Water Regulations: 816-F-09-004. U.S. Environmental Protection Agency, Washington, D.C., 6 p.

USEPA, 2006. Second Five-year Review Report for Homestake Mining Company Superfund site, Cibola County, New Mexico: U.S. Environmental Protection Agency, Dallas, TX, 126 p. <http://www.epa.gov/earth1r6/6sf/pdffiles/ hmc 2nd 5 year_review.pdf> (accessed 05.12.12).

USEPA, 2008a. Technical Report on Technologically Enhanced Naturally Occurring Radioactive Materials from Uranium Mining, vol. 1. Mining and Reclamation Background. U.S. Environmental Protection Agency, Washington, DC, 225 p.

USEPA, 2008b. Technical Report on Technologically Enhanced Naturally Occurring Radioactive Materials from Uranium Mining, vol. 2. Investigation of Potential Health, Geographic, and Environmental Issues of Abandoned Uranium Mines. U. S. Envioronmental Protection Agency, Washington, DC, $131 \mathrm{p}$.

USGS, 2007. Facing Tomorrow's Challenges - U.S. Geological Survey Science in the Decade 2007-2017: USGS Circular 1309, USGS, Reston, VA, 70 p.

Van Metre, P.C., Gray, J.R., 1992. Effects of uranium mining discharges on water quality in the Puerco River basin, Arizona and New Mexico. Hydrol. Sci. J./ Journal des Sciences Hydrologiques 37, 463-480.

Veeramani, H., Schofield, E.J., Sharp, J.O., Suvorova, E.I., Ulrich, K.U., Mehta, A., Giammar, D.E., Bargar, J.R., Bernier-Latmani, R., 2009. Effect of Mn(II) on the structure and reactivity of biogenic uraninite. Environ. Sci. Technol. 43, 65416547.

Veeramani, H., Alessi, D.S., Suvorova, E.I., Lezama-Pacheco, J.S., Stubbs, J.E., Sharp, J.O., Dippon, U., Kappler, A., Bargar, J.R., Bernier-Latmani, R., 2011. Products of abiotic $\mathrm{U}(\mathrm{VI})$ reduction by biogenic magnetite and vivianite. Geochim. Cosmochim. Acta 75, 2512-2528.

Vogt, T.C., Dixon, S.A., Strom, E.T., Johnson, W.F., Venuto, P.B., 1982a. In situ leaching of Crownpoint, New Mexico, uranium ore: Part 1-mineralogical frame of reference. J. Petrol. Technol. 34, 2200-2210.

Vogt, T.C., Strom, E.T., Dixon, S.A., Johnson, W.F., Venuto, P.B., 1982b. In situ leaching of Crownpoint, New Mexico, uranium ore: Part 2-laboratory study of a mild leaching system. Soc. Petrol. Eng. J. 22, 1013-1022.

Vogt, T.C., Strom, E.T., Venuto, P.B., Winget, J.E., Scoggins, M.W., 1984. In situ leaching of Crownpoint, New Mexico, uranium ore: Part 6 - Section 9 pilot test. J. Petrol. Technol. 36, 2243-2254.

Wall, J.D., Krumholz, L.R., 2006. Uranium reduction. Annu. Rev. Microbiol. 60, 149166.

Wan, J., Tokunaga, T.K., Brodie, E., Wang, Z., Zheng, Z., Herman, D., Hazen, T.C. Firestone, M.K., Sutton, S.R., 2005. Reoxidation of bioreduced uranium under reducing conditions. Environ. Sci. Technol. 39, 6162-6169.

Wang, Z., Lee, S.W., Kapoor, P., Tebo, B.M., Giammar, D.E., 2013. Uraninite oxidation and dissolution induced by manganese oxide: a redox reaction between two insoluble minerals. Geochim. Cosmochim. Acta 100, 24-40.

Wang, Z., Tebo, B.M., Giammar, D.E., 2014. Effects of $\mathrm{Mn}(\mathrm{II})$ on $\mathrm{UO}_{2}$ dissolution under anoxic and oxic conditions. Environ. Sci. Technol. 48, 5546-5554.

Wanty, R.B., Miller, W.R., Briggs, P.H., McHugh, J.B., 1999. Geochemical processes controlling uranium mobility in mine drainages. Rev. Econ. Geol. 6A, 201213.

Waugh, W.J., 2004. Design, performance, and sustainability of engineered covers for uranium mill tailings. Long-Term Performance Monitoring of Metals and Radionuclides in the Subsurface: Strategies, Tools and Case Studies. <http:// www.cistems.fsu.edu/manuscripts.htm> (accessed 06.12.12).

Waugh, W.J., Benson, C.H., Albright, W.H., 2009. Sustainable covers for uranium mill tailings, USA: alternative design, performance, and renovation. Presented at 12th International Conference on Environmental Remediation and Radioactive Waste Management, Liverpool, UK.

Wehrli, B., Sulzberger, B., Stumm, W., 1989. Redox processes catalyzed by hydrous oxide surfaces. Chem. Geol. 78, 167-179.

Wenrich, K.J., Van Gosen, B.S., Finch, W.I., 1995. Solution-Collapse Breccia Pipe U Deposits: Open-File Report 95-831. U.S. Geological Survey, Denver, CO, 272 p.

Wersin, P., Hochella, M.F., Persson, P., Redden, G., Leckie, J.O., Harris, D.W., 1994. Interaction between aqueous uranium(VI) and sulfide minerals: spectroscopic evidence for sorption and reduction. Geochim. Cosmochim. Acta 58, 2829 2843.

Wilkins, M.J., VerBerkmoes, N.C., Williams, K.H., Callister, S.J., Mouser, P.J., Elifantz, H., N'Guessan, A.L., Thomas, B.C., Nicora, C.D., Shah, M.B., Abraham, P., Lipton, M.S., Lovley, D.R., Hettich, R.L., Long, P.E., Banfield, J.F., 2009. Proteogenomic monitoring of Geobacter physiology during stimulated uranium bioremediation. Appl. Environ. Microbiol. 75, 6591-6599.

Williams, A.G.B., Scherer, M.M., 2004. Spectroscopic evidence for Fe(II)-Fe(III) electron transfer at the Fe oxide-water interface. Environ. Sci. Technol. 38, $4782-4790$.

Williams, K.H., Kemna, A., Wilkins, M.J., Druhan, J., Arntzen, E., N'Guessan, A.L., Long, P.E., Hubbard, S.S., Banfield, J.F., 2009. Geophysical monitoring of coupled microbial and geochemical processes during stimulated subsurface bioremediation. Environ. Sci. Technol. 43, 6717-6723.

Williams, K.H., Wilkins, M.J., N'Guessan, A.L., Arey, B., Dodova, E., Dohnalkova, A. Holmes, D., Lovley, D.R., Long, P.E., 2013. Field evidence of selenium bioreduction in a uranium-contaminated aquifer. Environ. Microbiol. Rep. 5, 444-452.

Williams, K.H., Long, P.E, Davis, J.A., Wilkins, M.J., N'Guessan, A.L., Steefel, C.I, Yang, L., Newcomer, D., Spane, F.A., Kerkhof, L.J., McGuinness, L., Dayvault, R., Lovley, D.R., 2011. Acetate availability and its influence on sustainable bioremediation of uranium-contaminated groundwater. Geomicrobiol J. 28, 519-539.

Winde, F., 2010. Uranium pollution of the Wonderfonteinspruit, 1997-2008. Part 1: uranium toxicity, regional background and mining related sources of uranium pollution. Water SA 36, 239-256.

Winde, F., van der Walt, I.J., 2004. The significance of groundwater-stream interactions and fluctuating stream chemistry on waterborne uranium contamination of streams-a case study from a gold mining site in South Africa. J. Hydrol. 287, 178-196.

Winde, F., Wade, P., van der Walt, IJ., 2004. Gold tailings as a source of waterbourne uranium contamination of streams-The Koekemoerspruit (South Africa) as a case study. Part III of III: Fluctuations of stream chemistry and their impacts on uranium mobility. Water SA 30, 233-239.

Wrighton, K.C., Thomas, B.C., Sharon, I., Miller, C.S., Castelle, C.J., VerBerkmoes, N.C. Wilkings, M.J., Hettich, R.L., Lipton, M.S., Williams, K.H., Long, P.E., Banfield, J.F. 2012. Fermentation, hydrogen, and sulfur metabolism in multiple uncultivated bacteria phyla. Science 337, 1656-1661.

Wu, W.M., Carley, J., Luo, J., Ginder-Vogel, M.A., Cardenas, E., Leigh, M.B., Hwang, C., Kelly, S.D., Ruan, C., Wu, L., Van Nostrand, J., Gentry, T., Lowe, K., Mehlhorn, T. Carroll, S., Luo, W., Fields, M.W., Gu, B., Watson, D., Kemner, K.M., Marsh, T., Tiedje, J., Zhou, J., Fendorf, S., Kitanidis, P.K., Jardine, P.M., Criddle, C.S., 2007. In situ bioreduction of uranium(VI) to submicromolar levels and reoxidation by dissolved oxygen. Environ. Sci. Technol. 41, 5716-5723.

Xu, H., Min, M., Zhen, J., Peng, X., Wang, J., Barton, L., Wang, Y., 2004. Enrichment of uranium inside wood: a natural analog from a sandstone-hosted roll-type uranium ore deposit. Mater. Res. Soc. Proc. 824, 479-484.

Yabusaki, S.B., Fang, Y., Long, P.E., Resch, C.T., Peacock, A.D., Komlos, J., Jaffe, P.R., Morrison, S.J., Dayvault, R.D., White, D.C., Anderson, R.T., 2007. Uranium removal from groundwater via in situ biostimulation: field-scale modeling of transport and biological processes. J. Contam. Hydrol. 93, 216-235.

Yabusaki, S.B., Fang, Y., Waichler, S.R., Long, P.E., 2010. Processes, Properties, and Conditions Controlling In Situ Bioremediation of Uranium in Shallow, Alluvial Aquifers: NUREG/CR-7014. Nuclear regulatory Commission, Office of Nuclear Regulatory Research, Washington, DC, 111 p.

Yabusaki, S.B., Fang, Y., Williams, K.H., Murray, C.J., Ward, A.L., Dayvault, R.D. Waichler, S.R., Newcomer, D.R., Spane, F.A., Long, P.E., 2011. Variably saturated flow and multicomponent biogeochemical reactive transport modeling of a uranium bioremediation field experiment. J. Contam. Hydrol. 126, 271-290.

Yelton, A.P., Williams, K.H., Fournelle, J., Wrighton, K.C., Handley, K.M., Banfield, J.F., 2013. Vanadate and acetate biostimilation of contaminated sediments decreases diversity, selects for specific taxa, and decreases aqueous $\mathrm{V}^{5+}$ concentration. Environ. Sci. Technol. 47, 6500-6509.

Ziegenbalg, G., 2006. A novel technology for sealing and immobilization - the use of precipitation processes from supersaturated conditions. In: Merkel, B., HascheBerger, A. (Eds.), Uranium in the Environment: Mining Impacts and Consequences. Springer, Berlin, pp. 449-458.

Zielinski, R.A., Meier, A.L., 1988. The association of uranium with organic matter in Holoceme peat: an experimental leaching study. Appl. Geochem. 3, 631-643. 